\title{
Cochrane
}

Library

Cochrane Database of Systematic Reviews

\section{Exercise for the management of cancer-related fatigue in adults} (Review)

Cramp F, Byron-Daniel J

Cramp F, Byron-Daniel J.

Exercise for the management of cancer-related fatigue in adults.

Cochrane Database of Systematic Reviews 2012, Issue 11. Art. No.: CD006145.

DOI: 10.1002/14651858.CD006145.pub3.

www.cochranelibrary.com 
TABLE OF CONTENTS

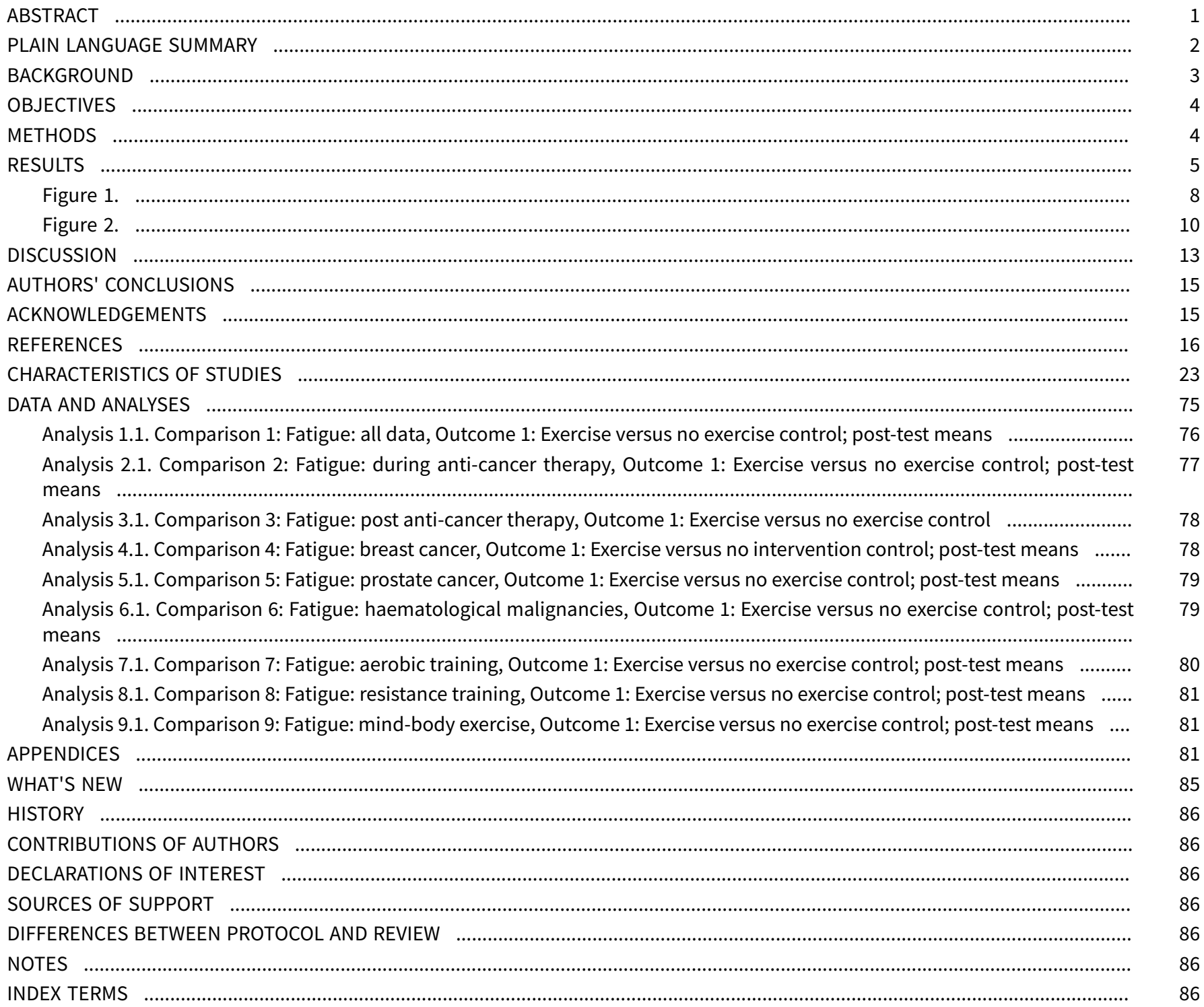


[Intervention Review]

\section{Exercise for the management of cancer-related fatigue in adults}

Fiona Cramp ${ }^{1}$, James Byron-Daniel ${ }^{2}$

1Faculty of Health \& Applied Sciences, University of the West of England, Bristol, UK. ${ }^{2}$ School of Psychology, University of the West of England, Bristol, UK

Contact: Fiona Cramp, fiona.cramp@uwe.ac.uk.

Editorial group: Cochrane Pain, Palliative and Supportive Care Group.

Publication status and date: Stable (no update expected for reasons given in 'What's new'), published in Issue 9, 2021.

Citation: Cramp F, Byron-Daniel J. Exercise for the management of cancer-related fatigue in adults. Cochrane Database of Systematic Reviews 2012, Issue 11. Art. No.: CD006145. DOI: 10.1002/14651858.CD006145.pub3.

Copyright @ 2012 The Cochrane Collaboration. Published by John Wiley \& Sons, Ltd.

\section{A B S T R A C T}

\section{Background}

Cancer-related fatigue is recognised as an important symptom associated with cancer and its treatment. A number of studies have investigated the effects of physical activity in reducing cancer-related fatigue. This is an updated version of the original Cochrane review published in The Cochrane Library (2008, Issue 1). The original review identified some benefits of physical activity on fatigue in cancer both during and after adjuvant treatment. We identified a number of limitations in the evidence, providing clear justification for an updated review.

\section{Objectives}

To evaluate the effect of exercise on cancer-related fatigue both during and after cancer treatment.

\section{Search methods}

We searched the Cochrane Central Register of Controlled Trials (CENTRAL) (Issue 1, 2011), MEDLINE (1966 to March 2011), EMBASE (1980 to March 2011), CINAHL (1982 to March 2011), British Nursing Index (January 1984 to March 2011), AMED (1985 to March 2011 ), SIGLE (1980 to March 2011) and Dissertation Abstracts International (1861 to March 2011) using key words. We also searched reference lists off all studies identified for inclusion and relevant reviews. In addition, we handsearched relevant journals and contacted experts in the field of cancerrelated fatigue.

\section{Selection criteria}

We sought and included randomised controlled trials (RCTs) that investigated the effect of exercise on cancer-related fatigue in adults.

\section{Data collection and analysis}

Two review authors independently assessed the risk of bias of studies and extracted data based upon predefined criteria. Where data were available we performed meta-analyses for fatigue using a random-effects model.

\section{Main results}

For this update we identified a total of 56 studies (4068 participants) for inclusion ( 28 from the original search and 28 from the updated search), with the majority carried out in participants with breast cancer ( 28 studies). A meta-analysis of all fatigue data, incorporating 38 comparisons, provided data for 1461 participants who received an exercise intervention and 1187 control participants. At the end of the intervention period exercise was seen to be statistically more effective than the control intervention (standardised mean difference (SMD) $-0.27,95 \%$ confidence interval $(\mathrm{Cl})-0.37$ to -0.17 ). Benefits of exercise on fatigue were observed for interventions delivered during or post-adjuvant cancer therapy. In relation to diagnosis, we identified benefits of exercise on fatigue for breast and prostate cancer but not for those with haematological malignancies. Finally, aerobic exercise significantly reduced fatigue but resistance training and alternative forms of exercise failed to reach significance. 


\section{Authors' conclusions}

The findings of the updated review have enabled a more precise conclusion to be made in that aerobic exercise can be regarded as beneficial for individuals with cancer-related fatigue during and post-cancer therapy, specifically those with solid tumours. Further research is required to determine the optimal type, intensity and timing of an exercise intervention.

\section{PLAIN LANGUAGE SUMMARY}

\section{The effect of exercise on fatigue associated with cancer}

Fatigue, or tiredness, is recognised as a side effect of cancer and its treatment. In the past people with cancer were encouraged to rest if they felt fatigued. It is important that individuals with cancer receive appropriate support and advice to help them cope with any side effects of the treatment or disease. Physical exercise has been suggested as helpful in reducing the fatigue that is associated with cancer. A number of studies have been carried out to investigate the effects of exercise both during and after treatment. The current review was carried out to evaluate the effect of physical exercise on fatigue related to cancer. Fifty-six studies, involving a total of 4068 participants, were included in this review. Results suggest that physical exercise such as aerobic walking and aerobic cycling can help to reduce fatigue both during and after treatment for cancer. The benefits of exercise on fatigue were observed specifically for people with breast cancer and prostate cancer. 


\section{B A C K G R O U N D}

This review is an update of a review previously published in The Cochrane Library (2008, Issue 1) on exercise for the management of cancer-related fatigue (Cramp 2008). As a result of improved therapy, people with cancer are surviving longer and having to deal with the long-term consequences of the disease and its therapy. Consequently there has been an increasing number of individuals who need supportive care to enhance their quality of life (Lucia 2003). This has led to an increasing recognition of the symptoms associated with cancer and cancer management with relief of these symptoms emerging as an important dimension of cancer patient care.

\section{Description of the condition}

Cancer-related fatigue is an abstract, multidimensional subjective experience, affecting $70 \%$ to $100 \%$ of the cancer patient population (Mock 2001b). It has a profound effect on the whole person, physically, emotionally and mentally (Ahlberg 2003), and can persist for months or even years following completion of treatment. It can have a phenomenal impact on a patient's life, interfering with daily activities (Curt 2000) and may also potentially have devastating social and economic consequences (Fletchner 2002). It can hinder a patient's chance of remission or even cure, owing to the effect it can have on the desire to continue with treatment (Morrow 2001).

In spite of the prevalence and impact of cancer-related fatigue there are limited data available with regards to the precise aetiology, pattern over time and exacerbating and relieving factors (Fletchner 2002), thus complicating the development of effective management interventions (Dimeo 2002). The aetiology of cancer-related fatigue remains to be fully established and a number of causes have been suggested, such as the effect of tumour and cancer treatment, comorbid medical conditions including anaemia, hypothyroidism, cytokines and sleep problems, psychological factors such as anxiety and depression, and loss of functional status (Lucia 2003; Wagner 2004; Mustian 2007). The cause of cancer-related fatigue may also differ between individuals as well as according to the phase of the disease and the type of treatment received (Ryan 2007).

\section{Description of the intervention}

The National Comprehensive Cancer Network (NCCN 2012) has developed guidelines for the management of cancer-related fatigue. Initially any treatable factors that may cause fatigue should be identified and treated. The panel identified several factors that are treatable namely: pain, emotional distress, sleep disturbance, anaemia, nutrition, activity level, medication side effects, alcohol/ substance abuse and comorbidities. If the patient does not have any treatable contributing factors or cancer-related fatigue persists, then additional treatment is recommended depending on the patient's clinical status. This incorporates education and counselling, general strategies for the management of fatigue, and pharmacological and non-pharmacological interventions. In line with these guidelines the role of non-pharmacological interventions in the management of cancer-related fatigue is supported by Mustian 2007 and colleagues who have identified psychosocial therapies, physical exercise and a range of other interventions as potentially beneficial. Activity enhancement is also recommended by the NCCN as one of the non-pharmacological interventions at all stages of the disease process: during active treatment, in disease-free patients on long-term follow-up and at the end of life (NCCN 2012).

The physical dimension of cancer-related fatigue is likely to have an organic aetiology (Dimeo 2001). The effect of treatment and a reduction in physical activity can lead to a reduction in physical performance (NCCN 2012). Thus, the patient requires an increased effort to accomplish normal everyday activities, which leads to the perception of fatigue. This is further exacerbated by impairment of skeletal muscle function intensified by a lack of activity (Lucia 2003).

\section{How the intervention might work}

Exercise has been demonstrated to be effective in reducing fatigue and improving the exercise tolerance of healthy individuals as well as those with long-term conditions (Mock 2005). It has been suggested that changes brought about by physical activity may counteract the negative effects the tumour and toxic therapy have on the capacity for physical performance (Dimeo 2002). Activity could reduce cancer-related fatigue by improving functional capacity, resulting in a reduced effort and improvement in the perception of fatigue (NCCN 2012). Rest, the preferred recommendation for cancer-related fatigue in the past, is likely to be counterproductive as inactivity leads to muscle wasting and a loss of cardiorespiratory fitness, leading to increased fatigue (Dimeo 2001). Winningham 1992 developed a theoretical framework for cancer-related fatigue (Winningham's Psychobiological-Entropy model) which proposes that a balance between rest and activity can reduce fatigue, whereas an imbalance can lead to deterioration suggesting that too little or too much exercise may exacerbate it. More recently a biobehavioural model has been suggested to explain the benefits that exercise may have upon cancer-related fatigue (Al-Majid 2009). The model encompasses biological, psycho-behavioral and functional variables that are implicated in the induction of cancer-related fatigue.

The benefit of exercise may not be limited to the improvement of the physical dimension of fatigue. It could also relieve the emotional and mental dimensions. Exercise has been demonstrated to improve mood and reduce anxiety and fear in patients (Dimeo 2001).

\section{Why it is important to do this review}

There are two complementary Cochrane systematic reviews focusing on the treatment of cancer-related fatigue at all stages of cancer. These complementary reviews have examined the role of drugs (Minton 2010) and psychosocial interventions (Goedendorp 2009) in modifying cancer-related fatigue. However, there is currently no definitive stand on exercise for cancer-related fatigue from the American College of Sports Medicine, with minimal detail given on exercise prescription in those that do recommend it (Lucia 2003; Mustian 2007). Furthermore there is limited information on specific groups of cancer patients where caution may be required (Mustian 2007). This review update was conducted to analyse the increasing number of trials and where possible to identify the optimal exercise for reducing cancer-related fatigue. 


\section{O B JECTIVES}

To evaluate the effect of exercise on cancer-related fatigue both during and after cancer treatment.

A secondary objective, subject to available data, was to explore the effect of exercise in different types of cancer populations. Groupings were determined based on tumour type, type of cancer treatment received and stage of cancer treatment, that is, either during or after treatment. Based upon the findings of the previous review it was also proposed to explore the effects of different modes of exercise.

\section{METHODS}

\section{Criteria for considering studies for this review}

\section{Types of studies}

We considered only randomised controlled trials (RCT) for inclusion.

\section{Types of participants}

We included studies that evaluated the effect of exercise on cancerrelated fatigue in adults of any age, regardless of gender, tumour type, tumour stage and type of cancer treatment. Participants may have been actively receiving treatment, be in long-term follow-up or receiving palliative care.

\section{Types of interventions}

Included studies needed to evaluate and report the effect of physical exercise on cancer-related fatigue. The studies should compare exercise with no exercise, a usual care group (i.e. no specific exercise programme prescribed) or an alternative treatment or exercise regime for fatigue associated with cancer The intervention could take place in any setting and be delivered to a group or individual participant. All types of physical exercise were considered for inclusion, including aerobic exercise, strength training and flexibility exercises. Studies that investigated an exercise programme accompanied by attempts to promote participant engagement were included. In contrast, studies that explored multi-dimensional programmes in which the effects of exercise alone could not be determined were excluded. Studies were also excluded if a specific exercise programme was not described and participants were only given advice or education about the potential benefits of exercise.

\section{Types of outcome measures}

The outcomes of interest were:

1. patient-reported fatigue measured using reliable and valid assessment tools;

2. exercise maintenance on follow-up;

3. time spent exercising;

4. valid and reliable measures of aerobic capacity;

5. quality of life measures;

6. anxiety;

7. depression;

8. self efficacy (the individual's belief in their own ability to be physically active)

\section{Search methods for identification of studies}

\section{Electronic searches}

Please see Appendix 1 for the search strategy.

We used the following databases to obtain relevant studies for this review (the original search was conducted up to July 2007):

- The Cochrane Central Register of Controlled Trials (CENTRAL) (Issue 1, 2011);

- MEDLINE (1966 to March 2011);

- EMBASE (1980 to March 2011);

- CINAHL (1982 to March 2011);

- British Nursing Index (January 1984 to March 2011);

- AMED (1985 to March 2011);

- SIGLE (1980 to March 2011);

- Dissertation Abstracts International (1861 to March 2011).

\section{Searching other resources}

- We checked the reference lists of all articles obtained for additional studies.

- We handsearched the following journals up to April 2011: Cancer, Journal of Clinical Oncology, Psycho-Oncology, Cancer Practice, Oncology Nursing Forum.

- We contacted four experts in the field of cancer-related fatigue in order to identify any research that may not have been published.

- We obtained unpublished literature through searches of conference proceedings up to June 2011.

- We attempted to communicate with the study authors to secure information not presented in the studies.

- There were no language restrictions.

\section{Data collection and analysis}

We retrieved all studies in which the abstract made reference to an exercise trial in a population of cancer participants in full. Where abstracts were not available and the study could not be excluded based upon the title alone we retrieved the full text. For a study to be included it had to include fatigue as an outcome measure and at least one treatment arm had to be exercise. Two independent review authors screened all the retrieved fulltext articles for inclusion criteria. Although there was initially some discrepancy based upon the appropriateness of the outcome measures, following discussion there was $100 \%$ agreement.

Two review authors extracted data from the included studies. If there was disagreement we proposed that there would be a meeting with a third independent reviewer to reach a consensus.

For the original review we assessed the methodological quality of each study using the Oxford quality scale, which is concerned with the presence and adequacy of randomisation, the presence and adequacy of blinding, and description of participant withdrawals (Jadad 1996).

In addition, for each study we extracted:

- number of participants in each arm;

- type of control group;

- demographic characteristics, including age and gender; 
- type of cancer;

- type of treatment and stage of treatment, for example during or after treatment;

- the exercise undertaken in each intervention group;

- duration of intervention, intensity and total number of exercise sessions;

- duration of follow-up;

- outcome measures employed, including means and standard deviations;

- attrition rates.

\section{Assessment of risk of bias in included studies}

For the update of the review we adapted the methods from those described by the Cochrane Pregnancy and Childbirth Group 2012. The authors independently assessed risk of bias for each study using the criteria outlined in the Cochrane Handbook for Systematic Reviews of Interventions (Higgins 2011) with any disagreements resolved by discussion. We assessed the following for each study:

1. Random sequence generation (checking for possible selection bias). We assessed the method used to generate the allocation sequence as: low risk of bias (any truly random process, e.g. random number table, computer random number generator); high risk of bias (any non-random process, e.g. odd or even date of birth, hospital or clinic record number); unclear risk of bias.

2. Allocation concealment (checking for possible selection bias). We assessed the method used to conceal allocation to interventions prior to assignment for whether intervention allocation could have been foreseen in advance of, or during, recruitment, or changed after assignment. We assessed the methods as: low risk of bias (e.g. telephone or central randomisation, consecutively numbered sealed opaque envelopes); high risk of bias (open random allocation, unsealed or non-opaque envelopes, alternation, date of birth); unclear risk of bias.

3. Blinding of outcome assessment (checking for possible detection bias). We assessed the methods used to blind study participants and outcome assessors from knowledge of which intervention a participant received. We considered studies to be at low risk of bias if they were blinded, or if we judged that the lack of blinding would be unlikely to affect the results. We assessed blinding specifically in relation to the fatigue outcome.

4. Incomplete outcome data (checking for possible attrition bias due to the amount, nature and handling of incomplete outcome data). We assessed the completeness of fatigue outcome data including attrition and exclusions from the analysis. We assessed methods as: low risk of bias (e.g. no missing outcome data, missing outcome data balanced across groups); high risk of bias (e.g. numbers or reasons for missing data imbalanced across groups, intention-to-treat analysis not performed); unclear risk of bias.

5. Selective reporting (checking for reporting bias). We assessed the methods as: low risk of bias (where it is clear that all of the study's pre-specified fatigue outcomes have been reported); high risk of bias (where not all the study's pre-specified fatigue outcomes have been reported); unclear risk of bias.

\section{Measures of treatment effect}

Fatigue outcomes were likely to be reported in different ways in the identified studies. It was therefore difficult to predict what data would be available to be combined. If the data were available, and it was appropriate to do so, we proposed that the studies would be combined in a meta-analysis. We proposed to calculate the mean difference in fatigue intensity between exercise and control groups including usual care and alternative treatment groups. Subgroup analysis would also be conducted if the data were available. Separate analysis would be implemented according to tumour type, for example breast cancer participants; treatment received, for example chemotherapy or radiotherapy; and the stage of treatment the participant was at when the exercise programme was administered, that is either during or after cancer treatment. If heterogeneity between studies was suspected, the possibility of utilising a random-effects model of meta-analysis would be considered. Further to this and if the information was available, we proposed to calculate the number of participants who experienced at least a $50 \%$ reduction in fatigue. This would be used to calculate the number needed to treat to benefit (NNTB) for a $50 \%$ reduction in fatigue.

\section{Assessment of heterogeneity}

Where appropriate, heterogeneity of the data was formally assessed using the 12 statistic (Higgins 2003). A value greater than $50 \%$ may represent substantial heterogeneity.

\section{RES U L T S}

\section{Description of studies}

In the original review, following a comprehensive literature search including screening of titles and abstracts (where available), we retrieved 51 full-text references. From these, we excluded 23 publications and identified 28 (2083 participants) as appropriate for inclusion in the current review. In the updated search we retrieved a further 58 full-text references following screening of titles and abstracts (where available). From these publications, we excluded 23 , a further seven were found to be linked to previous studies and we identified 28 ( $n=1985$ participants) as appropriate for inclusion in the updated review. The 28 studies from the original review and the 28 new studies provided a total of 56 studies (4068 participants) for inclusion in the review. In addition, through correspondence with study authors, we identified two protocols for appropriate studies; both studies were still in progress and not yet published and are therefore included in the Characteristics of ongoing studies table.

\section{Included studies}

The final selection, based on consensus, resulted in 28 studies being identified for inclusion in the original review and a further 28 identified in the update providing 56 studies for inclusion. Trial characteristics and outcomes can be seen in the Characteristics of included studies table. Five of the included studies incorporated two separate exercise groups and are therefore entered twice for the purposes of statistical analysis.

\section{Participants}

Participants had various cancer diagnoses although the majority of studies investigated breast cancer only (Mock 1994; Mock 1997; Segal 2001a; Galantino 2003; Courneya 2003b; McKenzie 2003; 
Pinto 2003; Headley 2004; Campbell 2005; Drouin 2005; Mock 2005; Pinto 2005; Courneya 2007a; Daley 2007; Heim 2007; Moadel 2007 Mutrie 2007; Yuen 2007a; Battaglini 2008; Hwang 2008; Milne 2008; Payne 2008; Carson 2009; Danhauer 2009; Rogers 2009; Chandwani 2010; Lee 2010; Sequeira 2012). Thirty-eight studies investigated participants with a specific cancer diagnosis, whereas 18 studies included participants with different diagnoses. The time since diagnosis varied widely between studies and in some cases within studies. Stage of treatment also varied between the included studies, with 25 of the studies investigating participants during cancer treatment (Mock 1994; Mock 1997; Dimeo 1999; Segal 2001a; Coleman 2003a; Segal 2003; Headley 2004; Windsor 2004; Campbell 2005; Drouin 2005; Mock 2005; Courneya 2007a; Monga 2007; Mutrie 2007; Battaglini 2008; Chang 2008; Hwang 2008; Payne 2008; Adamsen 2009; Mustian 2009; Rogers 2009; Segal 2009a; Chandwani 2010; Culos-Reed 2010; Dodd 2010a), 18 following treatment (Burnham 2002; Courneya 2003b; Galantino 2003; McKenzie 2003; Pinto 2003; Dimeo 2004; Pinto 2005; Thorsen 2005; Culos-Reed 2006; Daley 2007; Heim 2007; McNeely 2008; Milne 2008; Carson 2009; Shelton 2009; Lee 2010; van Weert 2010; Sequeira 2012) and the remaining 13 studies including participants both during and post-cancer treatment (Courneya 2003a; Courneya 2003c; Cohen 2004; Brown 2006; Moadel 2007; Yuen 2007a; Courneya 2008; Oh 2008; Courneya 2009; Danhauer 2009; Galvão 2010; Oh 2010; Santa Mina 2012).

The mean age of participants ranged from 39 to 70 years, with the majority of studies reporting a mean age that fell within the fifth decade. Twenty-nine of the studies recruited females only, which is perhaps not surprising given that 28 of the studies investigated breast cancer only. Twenty studies included a mixed sample of males and females with the remaining seven studies recruiting males only. For detailed information on study participants see the Characteristics of included studies table.

\section{Interventions}

Mode, intensity and timing of exercise differed across studies. Nineteen studies investigated home-based/unsupervised exercise programmes (Mock 1994; Mock 1997; Segal 2001a; Coleman 2003a; Courneya 2003a; Courneya 2003c; Galantino 2003; Headley 2004; Windsor 2004; Drouin 2005; Mock 2005; Pinto 2005; Thorsen 2005; Heim 2007; Yuen 2007a; Payne 2008; Mustian 2009; Culos-Reed 2010; Dodd 2010a), whereas 37 studies investigated supervised, institution-based exercise programmes (Dimeo 1999; Segal 2001b; Burnham 2002; Courneya 2003b; McKenzie 2003; Pinto 2003; Segal 2003; Cohen 2004; Dimeo 2004; Campbell 2005; Brown 2006; CulosReed 2006; Courneya 2007a; Daley 2007; Moadel 2007; Monga 2007; Mutrie 2007; Battaglini 2008; Chang 2008; Courneya 2008; Hwang 2008; McNeely 2008; Milne 2008; Oh 2008; Adamsen 2009; Carson 2009; Courneya 2009; Danhauer 2009; Rogers 2009; Segal 2009a; Chandwani 2010; Galvão 2010; Lee 2010; Oh 2010; van Weert 2010; Santa Mina 2012; Sequeira 2012). However, some studies investigating supervised exercise programmes encouraged participants to undertake additional home-based exercise. The remaining study compared a supervised and unsupervised exercise programme (Shelton 2009).

The mode of aerobic exercise varied between studies with 14 studies prescribing a walking programme (Mock 1994; Mock 1997; Segal 2001a; Galantino 2003; Windsor 2004; Drouin 2005; Mock 2005; Heim 2007; Monga 2007; Chang 2008; Payne 2008; Mustian 2009; Rogers 2009; Culos-Reed 2010), six prescribing stationary cycling (leg: Courneya 2003b; Dimeo 2004; Courneya 2008; Courneya 2009; arm: Dimeo 1999; McKenzie 2003) and a further 23 studies incorporating a range of modalities or allowing the participant to choose their preferred mode of aerobic exercise. One study did not report the mode of exercise carried out by participants (Sequeira 2012). Thirteen studies incorporated resistance training as a component of the exercise programme (Coleman 2003a; McKenzie 2003; Heim 2007; Battaglini 2008; Hwang 2008; Milne 2008; Adamsen 2009; Mustian 2009; Shelton 2009; Culos-Reed 2010; Galvão 2010; van Weert 2010; Santa Mina 2012) and four studies investigated resistance training in isolation (Segal 2003; Courneya 2007a; McNeely 2008; Lee 2010). Further to this, two studies included an aerobic training arm in addition to a resistance training arm (Yuen 2007a; Segal 2009a). Seven studies included flexibility training as a component of the exercise programme (Courneya 2003a; Courneya 2003c; Heim 2007; Battaglini 2008; Hwang 2008; Culos-Reed 2010; Lee 2010) although a number of studies incorporated routine stretching as part of the warm-up or cool-down, or both. Yoga was investigated in six studies (Cohen 2004; Culos-Reed 2006; Moadel 2007; Carson 2009; Danhauer 2009; Chandwani 2010), qigong in two studies (Oh 2008; Oh 2010) and seated exercise in one study (Headley 2004). The intensity of exercise varied greatly across studies with comparison complicated by the method used to monitor intensity in each study. This included methods such as heart rate monitoring, predicted oxygen uptake, patient perceived effort using the Borg scale and self paced exercise intensity. The frequency and duration of the exercise sessions also varied greatly between studies with participants encouraged to exercise between two times per week and daily for 10 to 120 minutes per session. In some studies the frequency or duration, or both, was increased incrementally each week whereas in other studies the duration was based upon individual tolerance. The overall time spent exercising for each of the groups was rarely reported.

In the majority of studies $(k=34)$ the comparison arm was described as a 'no intervention' or 'usual care' control group although in three of the 34 studies the participants received a weekly phone call regarding their symptom experience (Windsor 2004; Pinto 2005; Dodd 2010a). In a further 10 cases the comparison arm was a 'wait list' control (that is, the control group participants remained on a waiting list and were offered the intervention once the study was complete). Alternative comparison groups included relaxation training (Dimeo 2004), general stretching or range of movement exercises (Drouin 2005; Hwang 2008), light weights and stretching (McNeely 2008), Tai Chi (Galantino 2003) and group psychotherapy (Courneya 2003c). In two studies the participants in the control group received usual care but were also encouraged to remain active (Segal 2001a; Coleman 2003a) and in a further study the control arm patients were given written materials relating to general physical activity (Rogers 2009). In addition to the 'usual care' comparison group Daley 2007 also included a placebo group in which participants performed light intensity body conditioning exercises. No details were provided relating to the comparison group in the study by Burnham 2002. In two studies both arms received an exercise intervention, the first of these compared physical activity with physical activity delivered alongside a cognitive behavioural therapy to reduce fatigue (van Weert 2010); the second compared a group-based intervention to personal training (Santa Mina 2012). 
The intervention period varied greatly between studies with a range from three weeks (Dimeo 2004) to one year (Dodd 2010a) and a mode of 12 weeks ( $k=17$ studies). In some studies duration of the intervention varied between participants, being based upon the duration of cancer treatment. Stratification during randomisation was carried out in the majority of studies in attempt to account for this variation.

For detailed information on interventions see the Characteristics of included studies table.

\section{Outcome measures}

Fatigue was assessed using a wide range of outcome measures including the Functional Assessment of Cancer Therapy (FACT) (Courneya 2003a; Courneya 2003b; Courneya 2003c; Segal 2003; Courneya 2007a; Mutrie 2007; Courneya 2008; McNeely 2008; Courneya 2009; Danhauer 2009; Rogers 2009; Segal 2009a; Oh 2010; Santa Mina 2012), a linear analogue self assessment scale (Mock 1994; Mock 1997; Burnham 2002; Pinto 2005; Brown 2006), a numerical rating scale (Carson 2009), the fatigue sub scale of the Profile of Mood States (POMS) (Dimeo 1999; Coleman 2003a; Pinto 2003; Brown 2006; Culos-Reed 2006), the Piper Fatigue Scale (Mock 1997; Campbell 2005; Drouin 2005; Mock 2005; Daley 2007; Monga 2007; Yuen 2007a; Battaglini 2008; Payne 2008; Dodd 2010a), the Brief Fatigue Inventory (BFI) (Galantino 2003; Cohen 2004; Windsor 2004; Chang 2008; Hwang 2008; Mustian 2009; Shelton 2009; Chandwani 2010), the EORTC-QLQ-C30 fatigue sub scale (Dimeo 2004; Thorsen 2005; Culos-Reed 2006; Oh 2008; Adamsen 2009; Galvão 2010; Lee 2010; Sequeira 2012), the SF-36 vitality scale (Segal 2001a; McKenzie 2003; Adamsen 2009; Galvão 2010), the Functional Assessment of Chronic Illness Therapy-fatigue scale (Headley 2004; Moadel 2007; Mustian 2009), the Fatigue Severity Scale (FSS) (Culos-Reed 2010), the Multidimensional Fatigue Inventory (MFI) (Heim 2007; van Weert 2010) and the Schwartz Cancer Fatigue Scale (Milne 2008). Six studies incorporated more than one fatigue outcome measure (Mock 1997; Brown 2006; CulosReed 2006; Adamsen 2009; Mustian 2009; Galvão 2010).

In addition to measuring fatigue the following outcomes were recorded the most frequently: aerobic capacity/cardiovascular function ( $k=36)$, quality of life $(k=38)$, body composition $(k=18)$, physical activity levels $(k=15)$, general mood $(k=11)$, depression $(k=20)$ and anxiety $(k=13)$. Other outcomes assessed included flexibility, sleep variables, distress, symptom stress, strength, wellbeing, happiness, self esteem, satisfaction with life, chemotherapy completion rates, lymphoedema, self perception, psychosocial adjustment, body image and motivational readiness for change.

For detailed information on outcomes measures see the Characteristics of included studies table.

\section{Excluded studies}

The 56 publications retrieved and subsequently excluded did not meet the review inclusion criteria for the following reasons: two were reviews, 25 were not randomised controlled clinical trials, 10 did not report fatigue as an outcome measure, eight did not include an appropriate exercise intervention and one study did not report the results based upon the original group allocation. Details of the excluded studies can be found in the Characteristics of excluded studies table.

\section{Risk of bias in included studies}

We initially assessed the included studies for quality using the Oxford Quality Score (Jadad 1996) and in the updated review we also assessed studies using the Cochrane 'Risk of bias' tool (Higgins 2011). Following discussion there was $100 \%$ agreement in scores between the two review authors. The majority of studies scored two or three on the Oxford Quality Score. All studies lost two points due to the inability to conceal group allocation of study participants to the exercise intervention. It was also noted that observer blinding was rarely reported in the included studies. Studies that scored two lost a further point due to an incomplete description of drop-outs or an inadequate description of the method of randomisation. In general the Oxford Quality Score was higher in studies that were published more recently. However, it should also be noted that only five of the 56 studies were published prior to 2003. Oxford Quality Scores and 'Risk of bias' tables for each study are presented in the Characteristics of included studies table and a summary of the risk of bias is presented in Figure 1 and Figure 2. 
Figure 1. 'Risk of bias' summary: review authors' judgements about each risk of bias item for each included study.

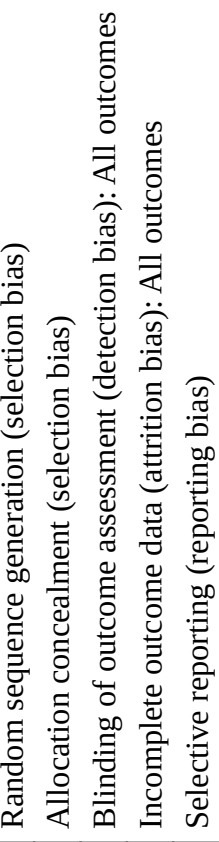

Adamsen 2009

Battaglini 2008

Brown 2006

Burnham 2002

Campbell 2005

Carson 2009

Chandwani 2010

Chang 2008

Cohen 2004

Coleman 2003a

Courneya 2003a

Courneya 2003b

Courneya 2003c

Courneya 2007a

Courneya 2007b

Courneya 2008

Courneya 2009

Culos-Reed 2006

Culos-Reed 2010

Daley 2007

Danhauer 2009

Dimeo 1999

Dimeo 2004

Dodd 2010a

Dodd 2010b

Drouin 2005

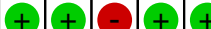


Figure 1. (Continued)

Dodd 2UIUb

Drouin 2005

Galantino 2003

Galvão 2010

Headley 2004

Heim 2007

Hwang 2008

Lee 2010

McKenzie 2003

McNeely 2008

Milne 2008

Moadel 2007

Mock 1994

Mock 1997

Mock 2005

Monga 2007

Mustian 2009

Mutrie 2007

Oh 2008

Oh 2010

Payne 2008

Pinto 2003

Pinto 2005

Rogers 2009

Santa Mina 2012

Segal 2001a

Segal 2001b

Segal 2003

Segal 2009a

Segal 2009b

Sequeira 2012

Shelton 2009

Thorsen 2005

van Weert 2010

Windsor 2004

Yuen 2007a

Yuen 2007b

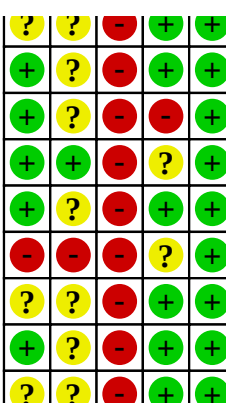

++ ? ++

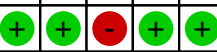

?

\begin{tabular}{cccc}
- & - & + & + \\
\hline
\end{tabular}

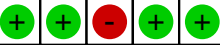

? ? -++
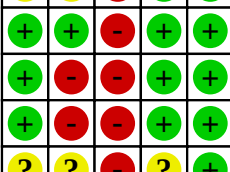
Figure 2. 'Risk of bias' graph: review authors' judgements about each risk of bias item presented as percentages across all included studies.

Random sequence generation (selection bias)

Allocation concealment (selection bias)

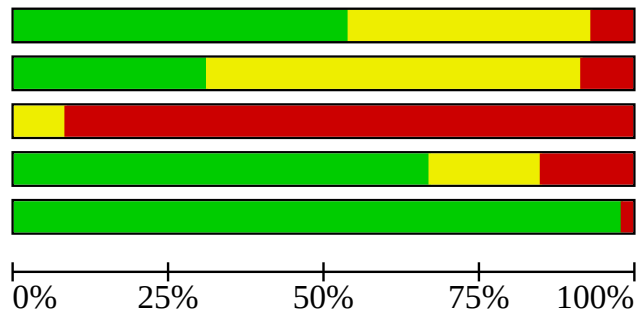

Blinding of outcome assessment (detection bias): All outcomes Incomplete outcome data (attrition bias): All outcomes

Selective reporting (reporting bias)

$0 \%$

High risk of bias

\section{Allocation}

Approximately half of the included studies reported appropriate random sequence generation. Allocation concealment was less well reported with over half the studies judged to be unclear.

\section{Blinding}

Unsurprisingly blinding of the fatigue outcome assessment was not performed adequately in any study. This is due to the self report nature of a subjective outcome such as fatigue combined with the complexity of blinding participants to a physical exercise intervention.

\section{Incomplete outcome data}

The majority of studies accounted for all participants and where appropriate performed intention-to-treat analysis.

\section{Selective reporting}

Fatigue outcomes as reported in the methods for each study were provided for the majority of the included studies.

\section{Other potential sources of bias}

A number of the included studies were limited by a small sample size with 24 studies recruiting fewer that 40 participants. Sample size ranged from 10 to 242 with a mean sample size of 69 participants and a median of 52.5. Thirty of the 56 studies either did not carry out or did not report a sample size calculation. The remaining 26 studies carried out a sample size calculation although only 10 of these recruited the required number of participants. Nine studies used fatigue as the basis of the sample size calculation with only four of the nine achieving their recruitment target.

Sixteen of the identified studies either provided no information regarding adherence to the prescribed intervention or did not report it in a meaningful way. The remaining 40 studies provided data on adherence to the exercise intervention with some of the studies also reporting exercise levels for the comparison group. Methods for reporting adherence varied between studies, for example, some studies reported the percentage of supervised sessions attended whereas others were based upon subjective reporting of exercise. Comparison between studies was complicated by the different methods used for reporting, however, for the studies that reported the percentage of supervised sessions attended adherence varied between $61 \%$ (Milne 2008) and $98.4 \%$ (Courneya 2003b). A few of the studies monitored activity in the comparison group and acknowledged that the level of exercise may have resulted in some participants in the control group carrying out similar levels of activity to individuals in the intervention group. Three studies compared time spent exercising between the intervention and comparison group; all three reported that the intervention group performed exercise for a statistically longer period during the intervention period (Courneya 2003c; Pinto 2005; Mutrie 2007). For analysis purposes all studies considered participants in the group to which they had been assigned, regardless of adherence, hence the estimated benefit of exercise did not take into consideration whether or not the participants adhered to the prescribed activity.

Only 11 of the 56 studies failed to provide adequate information regarding participants who withdrew or dropped out of the study. In the majority of cases participants who dropped out or withdrew were not included in the analysis although this was not entirely clear in all studies. Definition of intention-to-treat analysis varied between studies with some studies using this term to describe the inclusion of non-adherent participants in the analysis, whereas others used the term to describe the inclusion of participants who failed to complete the outcome measures or lost contact with the investigators, or both.

Follow-up assessment of long-term outcomes was poor with 35 of the 56 studies failing to assess outcomes beyond the end of the intervention period. From the remaining studies that did include a follow-up assessment, four did not present the follow-up data in the original publication (Headley 2004; Pinto 2005; Courneya 2007a; Culos-Reed 2010). The length of follow-up for the remaining studies varied from four weeks (Windsor 2004) to one year (Dodd 2010a) following the end of the intervention period.

The primary outcome was not identified in all studies, with the majority of studies employing multiple outcome measures. Fatigue reduction alone was the main purpose of the intervention in only eight studies (Dimeo 1999; Dimeo 2004; Mock 2005; Heim 2007; Yuen 2007a; Chang 2008; Adamsen 2009; Dodd 2010a). In the remaining studies fatigue was either one of two or more main outcomes, a secondary outcome or reported as a sub scale of a quality of life measure. In 11 of the studies improvement in quality of life was identified as the single main purpose of the intervention (Courneya 2003a; Courneya 2003c; Campbell 2005; Brown 2006; Courneya 2007a; Daley 2007; Moadel 2007; Mutrie 2007; Milne 2008; Chandwani 2010; Oh 2010). Thirteen studies identified two primary outcomes (Mock 1994; Mock 1997; Segal 2001a; Coleman 
2003a; Courneya 2003b; Galantino 2003; McKenzie 2003; Segal 2003; Headley 2004; Windsor 2004; Monga 2007; McNeely 2008; Santa Mina 2012) and 13 studies identified three or more outcomes without identifying the primary purpose of the intervention (Pinto 2003; Drouin 2005; Pinto 2005; Thorsen 2005; Hwang 2008; Oh 2008; Payne 2008; Danhauer 2009; Mustian 2009; Segal 2009a; CulosReed 2010; Galvão 2010; van Weert 2010). The tools used to assess each of the outcomes of interest varied greatly between studies making comparisons difficult. Some of the included studies did not report the results in full and often only where statistically significant differences were identified.

\section{Effects of interventions}

Twenty-eight studies were identified for inclusion in the original review and an additional 28 in the updated review, providing 56 studies for inclusion ( $n=4068$ participants). For the purposes of meta-analysis, where data were not reported in full, we made an attempt to contact the corresponding author $(n=30)$. Twelve of the 30 authors subsequently provided post-test mean data $+/$ standard deviation (SD) for the fatigue outcome employed. The remaining authors either did not respond, could not be located or reported that the data were not available. In the original review we carried out separate meta-analyses on fatigue data using posttest means and change data. The two comparisons provided very similar results and we subsequently decided to base the remaining comparisons on the post-test means as the data were more readily available. For the purposes of the updated review all comparisons were based upon post-test means.

Five studies were not appropriate for inclusion in the meta-analyses as they did not incorporate an acceptable control arm. The five studies excluded compared specific exercise with a general exercise control arm (Lee 2010), individually supervised versus a group exercise control (Santa Mina 2012), supervised exercise versus an unsupervised control (Shelton 2009), resistance exercise versus aerobic exercise (van Weert 2010) and finally exercise versus exercise and education (Sequeira 2012).

\section{Fatigue}

\section{All studies: exercise versus control, post-test means}

We used a meta-analysis to combine the post-test results of the 51 remaining studies providing 56 possible comparisons due to the inclusion of two intervention arms in five studies. However, post-test means +/- SD were not available for 18 of the 56 comparisons. The remaining 38 comparisons provided data for 1461 participants who received an exercise intervention and 1187 participants in the control arm. At the end of the intervention period exercise was statistically more effective than the control intervention (standardised mean difference (SMD) -0.27, 95\% confidence interval $(\mathrm{Cl})-0.37$ to -0.17$)$ with moderate statistical heterogeneity identified $\left(P=0.03 ; I^{2}=33.0 \%\right)$ (Analysis 1.1 ).

\section{Intervention timing}

Twenty-five studies provided separate data for participants receiving an exercise intervention during cancer treatment. We used a meta-analysis to combine the post-test results of the 25 studies with 28 comparisons possible due to the inclusion of two intervention groups in three studies. However, post-test means +/SD were not available for 10 of the 28 comparisons. The remaining 18 comparisons provided data for 824 participants who received an exercise intervention and 642 participants in the control arm. At the end of the intervention period exercise was statistically more effective than the control intervention (SMD $-0.23,95 \% \mathrm{Cl}-0.33$ to $-0.12)$ with no evidence of statistical heterogeneity $(P=0.94 ; 12=0 \%)$ (Analysis 2.1).

Nineteen studies investigated participants post-cancer treatment, however, four of these studies were not appropriate for inclusion in a meta-analysis due to the lack of an appropriate control arm (Shelton 2009; Lee 2010; van Weert 2010; Sequeira 2012). We also used a meta-analysis to combine the post-test results of the remaining 15 studies in which participants received an exercise intervention following cancer treatment with 15 comparisons possible. However, post-test means +/- SD were not available for five of the 15 comparisons. The remaining 10 comparisons provided data for 272 participants who received an exercise intervention and 267 participants in the control arm. At the end of the intervention period exercise was statistically more effective than the control intervention (SMD $-0.44,95 \% \mathrm{Cl}-0.79$ to -0.09 ) with a high level of statistical heterogeneity detected $\left(P<0.0002 ; I^{2}=72.0 \%\right)$ (Analysis 3.1).

The remaining studies recruited a mixed sample of participants during and post-treatment for cancer and did not provide separate results.

\section{Disease-specific comparisons}

The majority of studies were carried out in breast cancer populations ( $k=28$ studies that only recruited breast cancer participants; $n=1671$ participants). Two of these studies were not appropriate for inclusion in a meta-analysis due to the lack of an appropriate control arm (Lee 2010; Sequeira 2012). We used a meta-analysis to combine the post-test results of the remaining 26 studies, with 29 comparisons possible due to the inclusion of two intervention groups in three studies. However, post-test means +/SD were not available for 11 of the 29 comparisons. The remaining 18 comparisons provided data for 672 participants who received an exercise intervention and 511 participants in the control arm. At the end of the intervention period exercise was statistically more effective than the control intervention (SMD $-0.35,95 \% \mathrm{Cl}-0.51$ to $-0.19)$ with a moderate level of statistical heterogeneity detected ( $P$ $=0.06 ; 1^{2}=36.0 \%$ ) (Analysis 4.1).

Seven studies were carried out in prostate cancer populations with an overall total of 491 participants. One study was not appropriate for inclusion in the meta-analysis due to the lack of an appropriate control arm (Santa Mina 2012). We used a meta-analysis to combine the post-test results of the remaining six studies, with seven comparisons possible due to the inclusion of two intervention groups in one study. However, post-test means +/- SD were not available for one of the seven comparisons. The remaining six comparisons provided data for 239 participants who received an exercise intervention and 176 participants in the control arm. At the end of the intervention period exercise was statistically more effective than the control intervention (SMD $-0.45,95 \% \mathrm{Cl}-0.78$ to -0.11$)$ although a high level of statistical heterogeneity was detected $\left(P=0.03 ; 1^{2}=59.0 \%\right)$ (Analysis 5.1).

Five studies were carried out in populations with haematological malignancies (lymphoma, myeloma and leukaemia) with an overall total of 260 participants. One study was not appropriate for inclusion in the meta-analysis due to the lack of an appropriate 
control arm (Shelton 2009). We used a meta-analysis to combine the post-test results of the remaining four studies providing four comparisons. The comparisons provided data for 114 participants who received an exercise intervention and 106 participants in the control arm. At the end of the intervention period there was no statistically significant difference between the exercise and the control arm (SMD $-0.15,95 \% \mathrm{Cl}-0.42$ to 0.11 ) with no evidence of statistical heterogeneity detected $\left(P=0.91 ; 1^{2}=0 \%\right)$ (Analysis 6.1).

Two further studies recruited disease-specific cohorts, specifically a colorectal cancer population (Courneya 2003a) and a head and neck cancer population (McNeely 2008). The remaining studies ( $\mathrm{k}=$ 14) recruited participants from more than one diagnostic group.

\section{Mode of exercise}

The majority of studies incorporated an aerobic exercise arm ( $\mathrm{k}=$ 30 ), although one of the studies was not appropriate for inclusion in a meta-analysis due to the lack of an appropriate control arm (van Weert 2010). The remaining 29 studies provided 31 possible comparisons due to the inclusion of two intervention groups in two studies. However, post-test means +/- SD were not available for nine of the 31 comparisons. The remaining 22 comparisons provided data for 832 participants who received an aerobic exercise intervention and 701 participants in the control arm. At the end of the intervention period aerobic exercise was statistically more effective than the control intervention (SMD $-0.22,95 \% \mathrm{Cl}-0.34$ to $-0.10)$ with a moderate level of statistical heterogeneity detected ( $P$ $\left.=0.20 ; 1^{2}=20.0 \%\right)$ (Analysis 7.1$)$.

Six studies included a resistance exercise arm although one of the studies was not appropriate for inclusion in a meta-analysis due to the lack of an appropriate control arm (Lee 2010). The remaining five studies provided data for 237 participants who received a resistance exercise intervention and 164 participants in the control arm. At the end of the intervention period resistance exercise was not statistically more effective than the control intervention (SMD $-0.18,95 \% \mathrm{Cl}-0.39$ to 0.02 ) with no evidence of statistical heterogeneity detected $\left(P=0.91 ; 1^{2}=0 \%\right)$ (Analysis 8.1).

Eight studies investigated low-intensity mind-body exercises, specifically yoga or qigong, providing eight possible comparisons for inclusion in a meta-analysis. However, post-test means +/- SD were not available for five of the eight comparisons. The remaining three comparisons provided data for 117 participants who received a mind-body exercise intervention and 77 participants in the control arm. At the end of the intervention period mind-body exercise was not statistically different to the control (SMD -0.10, $95 \% \mathrm{Cl}-0.39$ to 0.19 ) with no evidence of statistical heterogeneity detected $\left(P=0.53 ; 1^{2}=0 \%\right)$ (Analysis 9.1).

The remaining studies investigated multimodal exercise interventions, usually incorporating aerobic and resistance training.

\section{Long-term outcomes}

The above results were based upon post-intervention data as only 12 of the included studies recorded and presented follow-up data. Five of these studies investigated the effects of an exercise programme delivered during cancer therapy (Windsor 2004; Mutrie 2007; Mustian 2009; Chandwani 2010; Dodd 2010a). Four of the five studies reported that the differences in fatigue levels between intervention and control arm were not significant post-intervention or at follow-up (Windsor 2004; Mutrie 2007; Chandwani 2010; Dodd 2010a). Duration of follow-up was one month (Windsor 2004), three months (Chandwani 2010), six months (Mutrie 2007) and one year (Dodd 2010a) following the intervention. In contrast Mustian 2009 reported that statistically significant improvements in fatigue in the intervention group compared to the control arm were maintained at three months.

Four of the studies that included a long-term follow-up investigated the effects of an exercise programme delivered post-cancer therapy (Daley 2007; Heim 2007; Milne 2008; Sequeira 2012). Daley 2007, Milne 2008 and Sequeira 2012 reported no differences between study arms with regard to fatigue immediately postintervention or at 24 week/six-month follow-up. In contrast Heim 2007 reported that statistically significant improvements in fatigue in the intervention group compared to the control arm were maintained at three months.

The remaining three studies that included a long-term follow-up investigated a mixed sample of patients during and post-cancer therapy (Cohen 2004; Brown 2006; Courneya 2009). Cohen 2004 stated that outcomes were recorded at one and three months after baseline although there is no differentiation between the two time points in the reported results. Brown 2006 implemented a four-week intervention and participants were followed up post-intervention, at eight weeks and at 27 weeks. At eight weeks statistically fewer participants in the control arm reported clinically significant fatigue compared to the intervention arm. No statistically significant differences were reported between groups at eight or 27 weeks. The final study reported no significant differences in fatigue between study arms at the end of the intervention or at the six-month follow-up (Courneya 2009).

\section{Exercise Maintenance on Follow-up}

Exercise maintenance was rarely reported and the methods employed were mainly self report and only completed by a small number of study participants.

\section{Time Spent Exercising}

Time spent exercising was rarely reported and the methods employed were mainly self report and only completed by a small number of study participants.

\section{Aerobic capacity}

Thirty-eight of the 56 studies measured aerobic capacity or physical fitness, or both. The measures used varied between studies with seven studies employing $\mathrm{VO}_{2}$ max (an indicator of cardiorespiratory endurance and aerobic fitness) and the remaining studies employing alternative measures of physical fitness or endurance. Fifteen of the 38 studies reported no difference between the intervention and control groups for post-test aerobic capacity (Segal 2001a; Burnham 2002; Coleman 2003a; Courneya 2003a; Courneya 2003c; Galantino 2003; Mock 2005; Culos-Reed 2006; Heim 2007; Mustian 2009; Rogers 2009; Shelton 2009; Culos-Reed 2010; Galvão 2010; Santa Mina 2012) although it should be noted that two of these studies compared exercise interventions rather than a no exercise control arm (Shelton 2009; Santa Mina 2012). Seventeen of the 38 studies demonstrated a statistically significant difference in aerobic capacity or physical fitness between the intervention and control arm in favour of the intervention (Mock 1994; Mock 1997; Courneya 2003b; Windsor 2004; Campbell 2005; 
Pinto 2005; Thorsen 2005; Courneya 2007a; Daley 2007; Monga 2007; Mutrie 2007; Chang 2008; Courneya 2008; Milne 2008; Adamsen 2009; Courneya 2009; Segal 2009a). Four of the remaining six studies reported improvements over time but no betweengroup comparisons were provided (Pinto 2003; Dimeo 2004; Drouin 2005; Yuen 2007a). One study did not provide any statistical analysis of the aerobic capacity data (Dodd 2010a) and the final study did not reassess aerobic capacity post-intervention (Battaglini 2008).

Five studies investigated the relationship between aerobic capacity and fatigue; three reported no statistically significant correlation between change in aerobic performance and fatigue (Courneya 2003a; Dimeo 2004; Drouin 2005), whereas Mock 2005 and Milne 2008 reported a statistically significant association between improvements in aerobic fitness and subjective fatigue.

\section{Quality of life}

Twenty of the 56 studies did not measure quality of life (QoL) and a further study did not report the quality of life outcome data within the results (Galantino 2003). The remaining 35 studies most frequently used the Functional Assessment of Cancer Therapy to assess QoL, although the version used varied between studies, for example, eight studies used the FACT-Breast (FACT-B) and eight the FACT-general (FACT-G). Other measures used to assess QoL included the Satisfaction with Life Scale (SWLS), SF-36, the EORTC-QLQ-C30, the QoL Index for Cancer and the Functional Assessment of Chronic Illness Therapy-Fatigue. Six studies used two measures to assess QoL and one study employed three different QoL measures. The findings were not always consistent between measures.

Sixteen studies reported no statistically significant difference in post-test QoL between the intervention and control arms (Segal 2001a; Dimeo 2004; Thorsen 2005; Courneya 2007a; Moadel 2007; Courneya 2008; McNeely 2008; Oh 2008; Adamsen 2009; Danhauer 2009; Rogers 2009; Segal 2009a; Culos-Reed 2010; Lee 2010; Santa Mina 2012; Sequeira 2012), whereas 17 studies reported that exercise was statistically more beneficial to QoL than the control intervention (Burnham 2002; Courneya 2003a; Courneya 2003b; Courneya 2003c; Segal 2003; Headley 2004; Culos-Reed 2006; Daley 2007; Heim 2007; Monga 2007; Hwang 2008; Milne 2008; Courneya 2009; Mustian 2009; Chandwani 2010; Galvão 2010; Oh 2010).

Campbell 2005 assessed QoL using the FACT-G, FACT-B and the SWLS although the FACT-G was identified as the primary outcome of interest. The FACT-G as the primary outcome demonstrated a statistically significant improvement in QoL pre-post test in the exercise arm compared to the control arm. However, the FACT-B and SWLS did not demonstrate statistically significant differences between arms. Mutrie 2007 employed the FACT-G as the primary measure of QoL in addition to the FACT-B. Results demonstrated no statistically significant differences between arms in the FACT$G$ although the FACT-B showed a statistically significant difference between arms post-intervention in favour of the exercise arm.

\section{Anxiety}

Twenty-one of the 56 studies measured anxiety by means of the State Trait Anxiety Inventory ( $k=7)$, the Profile of Mood State (POMS) Tension-Anxiety sub scale $(k=7)$, a visual analogue scale (VAS) $(k=3)$, the Hospital Anxiety and Depression Scale (HADS) (k $=2$ ), or the Distressed Mood Index $(\mathrm{k}=1)$. In addition, one study measured Social Physique Anxiety which assesses an individual's anxiety in regard to real or perceived evaluation of their physique by others (Milne 2008). One of the 21 studies only measured anxiety at baseline (Brown 2006) and a further study only reported a total HADS score with no separate anxiety data (Heim 2007). Thirteen of the remaining 19 studies that measured anxiety reported no statistically significant benefits of exercise compared to a control arm (Mock 1994; Coleman 2003a; Courneya 2003a; Courneya 2003c; Cohen 2004; Drouin 2005; Pinto 2005; Thorsen 2005; Courneya 2007a; Moadel 2007; Chang 2008; Courneya 2009; Chandwani 2010). Further to this, Burnham 2002 reported that anxiety improved over time in the exercise intervention arm but there was no statistically significant difference in anxiety compared to the control arm. Dimeo 1999 also reported a statistically significant improvement over time in the exercise arm but no comparison with the control arm was reported. Mock 1997, Culos-Reed 2006 and Oh 2010 reported a statistically beneficial effect of exercise on anxiety compared to a control. In relation to social physique anxiety Milne 2008 also reported exercise to be statistically more effective than a control.

\section{Depression}

Twenty-eight of the 56 studies incorporated an outcome measure for depression including the Centre for Epidemiological StudiesDepression Scale (CES-D) ( $k=10)$, POMS-depression sub scale $(k=9)$, the Beck Depression Inventory $(k=4)$, a VAS $(k=3)$ and the HADS $(k=2)$. Nineteen of the 28 studies that measured depression reported no statistically significant difference between the intervention and control arm post-test (Mock 1997; Dimeo 1999; Burnham 2002; Coleman 2003a; Courneya 2003a; Courneya 2003c; Pinto 2003; Cohen 2004; Thorsen 2005; Culos-Reed 2006; Courneya 2007a; Monga 2007; Mutrie 2007; Chang 2008; Payne 2008; Chandwani 2010; Culos-Reed 2010; Dodd 2010a; Lee 2010). A further two studies did not report the results from the depression outcome measure (Pinto 2005; Brown 2006) and one study only reported a total HADS score (Heim 2007). Three studies reported a significant improvement in depression in the exercise arm compared to the control arm at the end of the intervention (Courneya 2009; Danhauer 2009; Oh 2010). Daley 2007 also reported statistically less depression following exercise compared to the control arm, however, depression was also statistically less in the placebo exercise group compared to the control arm. Drouin 2005 reported a statistically significant improvement in depression pre-post test with no corresponding improvement in the control arm, however, statistical analysis for arm by time interaction was not reported. Finally, Mock 1994 reported statistically worse depression in the control arm compared to the intervention arm mid-way through chemotherapy treatment. This difference was not maintained one month following chemotherapy.

\section{Self efficacy}

Only one of the included studies measured exercise self efficacy (Pinto 2005) with the results reported in a separate publication. No statistically significant mediating relationship was demonstrated between self efficacy and minutes of moderate-intensity activity undertaken.

\section{DISCUSSION}

This review provides evidence that exercise is beneficial in the management of cancer-related fatigue. Statistically significant improvements in fatigue were identified following an exercise 
programme carried out either during cancer therapy or following cancer therapy. Further to this, statistically significant beneficial effects were identified specific to breast cancer and prostate cancer populations but not for those with haematological malignancies. It remains to be determined whether the type of cancer treatment alters the beneficial effect of exercise on cancer-related fatigue. Statistically beneficial effects were identified following aerobic training but not following resistance training or low-intensity mindbody interventions.

\section{Limitations of the review}

This review has incorporated a diverse range of studies with small numbers in several of them. There is a considerable degree of clinical heterogeneity between studies in terms of adjuvant therapy, mode and intensity of exercise, and stage and type of cancer. In addition, moderate statistical heterogeneity was present for the total fatigue $\left(P=0.03 ; 1^{2}=33.0 \%\right)$, breast cancer fatigue $(P=$ $0.06 ; 12=36.0 \%)$ and the aerobic exercise $(P=0.20 ; 12=20.0 \%)$ metaanalyses. A high level of statistical heterogeneity was present in the meta-analyses of studies investigating exercise after cancer therapy $\left(\mathrm{P}<0.0002 ; \mathrm{I}^{2}=72.0 \%\right)$ and in the prostate cancer population $(\mathrm{P}=$ $\left.0.03 ; 1^{2}=59.0 \%\right)$. However, the meta-analysis of studies carried out during cancer therapy $\left(\mathrm{P}=0.94 ; \mathrm{I}^{2}=0 \%\right)$, in haematological patients $\left(P=0.91 ; 1^{2}=0 \%\right)$, for resistance exercise $\left(P=0.91 ; 1^{2}=0 \%\right)$ and for mind-body exercise $\left(P=0.53 ; 1^{2}=0 \%\right)$ provided no evidence of statistical heterogeneity. The lack of statistical heterogeneity does not exclude heterogeneity, given the small numbers.

Despite a comprehensive search strategy all studies included were published in the English language. This may reflect selective publication of English language studies with statistically significant findings.

Data were not available for the purpose of meta-analysis for all studies retrieved and identified as suitable. The studies which have not reported the data in full tended to be those that have not identified a favourable outcome for exercise, therefore the results of the meta-analysis may have been biased in the direction of a positive outcome, making exercise appear more effective. Selective reporting of statistically significant outcomes may also have occurred.

For the purpose of inclusion in the review all studies recorded fatigue as an outcome, however, the primary purpose of the exercise interventions varied between studies. The exercise may therefore have been designed for an alternative purpose, resulting in a lack of beneficial effect for fatigue.

The results of the review should not be considered in isolation as there are a range of non-pharmacological interventions that may be considered beneficial in the management of cancer-related fatigue. Interventions that may be delivered in conjunction with an exercise programme include, but are not limited to, psychosocial therapies (Jacobsen 2007; Goedendorp 2009), stress management, nutrition therapy and sleep therapy (Mustian 2007).

\section{Limitations of the included studies}

The quality of the included studies was variable with the more recent studies generally being of better quality. It is acknowledged that blinding participants to an exercise intervention may not be a feasible option although methods to reduce this risk of bias should be carefully considered in future trials.

Few of the included studies provided information about people who refused participation in the trial. It is possible that the included participants differed statistically to those who refused participation, particularly in relation to their attitudes towards an exercise programme. It is possible that those who declined to participate would not have achieved the same benefits from an exercise programme as those who chose to participate. Some studies did indicate the main reasons for individuals refusing to participate which included a lack of interest in the study, a refusal or inability to travel, being too busy or having other commitments, a refusal to be randomised and not wanting to be reminded of their cancer.

Statistical power was limited by the small number of participants in several studies. Furthermore, in several studies, fatigue was not identified as the primary outcome, thus sample size calculations (where reported) were based upon a different outcome measure.

The majority of studies were carried out with breast cancer populations. Further research in this area needs to include participants with various cancer diagnoses or other specific cancer populations at various stages of disease, including those receiving palliative care.

In some studies the control groups received less attention from healthcare or research staff, or both, in comparison to the intervention groups. The additional attention may have resulted in a systematic bias (Hawthorne effect) in favour of the intervention.

Few studies included long-term follow-up measures and these were not always reported. Further to this a number of studies implemented short-term interventions (approximately three weeks) which may not have been long enough to produce any statistically significant effects in relation to fatigue.

According to the most recent recommendations from the American College of Sports Medicine (ACSM) (Garber 2011) adults should undertake moderate-intensity aerobic physical activity for at least 30 minutes on five days per week or vigorous intensity aerobic physical activity for at least 20 minutes on three days each week. The majority of exercise interventions reviewed did not reach these recommendations as exercise was only undertaken two to three times per week at moderate intensity. Twelve of the studies included an intervention that met these recommendations although the participants may have been advised to start at a lower level and progress to 30 minutes on five days per week (Mock 1994; Mock 1997; Segal 2001a; Courneya 2003a; Courneya 2003c; Dimeo 2004; Drouin 2005; Mock 2005; Pinto 2005; Adamsen 2009; Mustian 2009; Rogers 2009). This step-wise progression is in line with the recommendations from the ACSM (Garber 2011). It should be noted that the ACSM guidelines were developed for healthy individuals and may need to be adapted for cancer survivors according to the stage of disease and adjuvant treatment. ACSM have developed guidelines for older adults which highlight the importance of combined aerobic, resistance and flexibility exercises (ChodzkoZajko 2009). These guidelines may be more appropriate for cancer survivors but due to insufficient evidence the optimal exercise programme has not yet been established (Chodzko-Zajko 2009). This is in line with the ACSM Roundtable Consensus Statement that recognised the need to adapt exercise programmes for the 
individual cancer survivor according to health status, adjuvant treatment and anticipated disease trajectory (Schmitz 2010). The statement does, however, recommend that all cancer survivors should maintain and increase muscle mass (Schmitz 2010). The effect of resistance training upon fatigue is inconclusive as although there was a trend observed in favour of resistance training this failed to reach significance. In agreement with the current review the consensus group concluded that there was insufficient evidence to recommend alternative forms of exercise such as yoga and tai chi (Schmitz 2010).

\section{Outcome measures}

A wide range of unidimensional and multidimensional outcome measures were used in the included studies which has prevented direct comparisons between studies. Data regarding fatigue were not always reported in full or adequately for the purposes of combining outcomes in a meta-analysis. We made attempts to contact authors where data were not available. It is recommended that multidimensional measures should be used to accurately assess fatigue to ensure that the effects of the intervention are captured in full. For example, an exercise intervention may have beneficial effects on mental and emotional fatigue levels but not physical fatigue levels. These effects would not be captured with a unidimensional tool.

The fatigue measures that were used do not have validated cut-off scores for mild/moderate/severe fatigue. In addition only one of the outcome measures used had validated minimal clinically important differences (MCIDs) (FACT-F; Cella 2002), hence it was not possible to determine the number needed to treat to benefit (NNTB) from the data obtained. Included studies did not provide estimates of effect size that could be pooled.

\section{Adherence and contamination}

Several studies indicated that participants completed exercise diaries although the results of these were frequently not reported. The accuracy of reporting in exercise diaries has also been questioned (Montoye 1996). Group contamination has previously been reported in studies investigating exercise. This may occur when the control participants undertake exercise or the exercise group do not adhere to the programme. Further contamination may occur when participants do not undertake the exercise at the prescribed intensity or for the prescribed duration. Monitoring of exercise is more difficult when the prescribed programme is homebased or unsupervised, or both. It is possible that implementation of an exercise programme should be accompanied by a behavioural change intervention to ensure that participants are supported. Only one study monitored participants' self efficacy, which may be an important predictor of adherence to the exercise intervention (Pinto 2005). Adherence to an exercise programme may be lower during cancer treatment as a result of associated adverse effects (Oldervoll 2004), hence patients may require additional support to remain active at this time. Recent research has indicated that providing cancer patients with supporting printed material regarding the exercise or with physical activity monitoring devices may increase levels of physical activity (Vallance 2007).

\section{AUTHORS' CONCLUSIONS}

\section{Implications for practice}

Thirty studies provided overall evidence that aerobic exercise is beneficial in the management of fatigue both during and after cancer treatment and should therefore be considered as one component of a management strategy for fatigue that may include a range of other interventions and education. These findings related specifically to those with solid tumours.

\section{Implications for research}

Further work is necessary to determine the most effective parameters of exercise for fatigue management including multimodal exercise (combined aerobic and resistance), frequency and duration of each exercise session, and intensity of exercise. Future studies should also incorporate a long-term follow-up. Twenty eight of the included studies were carried out in breast cancer populations therefore future research needs to be undertaken with a broad range of diagnoses, including patients with advanced disease and those receiving palliative care.

Consensus is also needed on the most appropriate multidimensional outcome measure to use. Further work is required to determine cut-off scores and minimal clinically important differences (MCID) for each of the selected measures.

Future research also needs to consider issues of maximising adherence and promoting self efficacy to exercise as well as identifying the barriers and facilitators to exercise in people with a cancer diagnosis. Other limitations of the existing research that need to be addressed include concealment of group allocation and observer blinding. Trials also need to be adequately powered to detect a change in fatigue. It is likely that the large number of studies with small numbers of participants may be due to limited funding available for non-commercial trials. Funding agencies may therefore like to consider funding large studies to determine optimal exercise parameters for this patient group.

\section{ACKNOWLEDGEMENTS}

This research was supported in part by the National Institute for Health Research (NIHR) Health Technology Assessment programme. The views and opinions expressed therein are those of the authors and do not necessarily reflect those of the funding agency.

The search strategy was developed with the assistance of Sylvia Bickley and the review update search was supported by Jane Hayes, Trials Search Co-ordinator for the Cochrane Pain, Palliative and Supportive Care Review Group.

Gillian Prue and Dr Jackie Gracey contributed to the development of the initial review protocol. 


\section{R E F E R E N C E S}

\section{References to studies included in this review}

\section{Adamsen 2009 \{published data only\}}

Adamsen L, Quist M, Andersen C, Møller T, Herrstedt J, Kronborg D, et al. Effect of a multimodal high intensity exercise intervention in cancer patients undergoing chemotherapy: randomised controlled trial. BMJ 2009;339:895-9.

\section{Battaglini 2008 \{published data only\}}

Battaglini CL, Mihalik JP, Bottaro M, Dennehy C, Petschauer MA, Hairston LS, et al. Effect of exercise on the caloric intake of breast cancer patients undergoing treatment. Brazilian Journal of Medical and Biological Research 2008;41(8):709-15.

\section{Brown 2006 \{published data only\}}

Brown P, Clark MM, Atherton P, Huschka M, Sloan JA, Gamble G, et al. Will improvement in quality of life (QOL) impact fatigue in patients receiving radiation therapy for advanced cancer? American Journal of Clinical Oncology 2006;1:52-8.

\section{Burnham 2002 \{published data only\}}

Burnham TR, Wilcox A. Effects of exercise on physiological and psychological variables in cancer survivors. Medicine and Science in Sports and Exercise 2002;34(12):1863-7.

\section{Campbell 2005 \{published data only\}}

Campbell A, Mutrie N, White F, McGuire F, Kearney N. A pilot study of a supervised group exercise programme as a rehabilitation treatment for women with breast cancer receiving adjuvant treatment. European Journal of Oncology Nursing 2005;9:56-63.

\section{Carson 2009 \{published data only\}}

Carson JW, Carson KM, Porter LS, Keefe FJ, Seewaldt VL. Yoga of Awareness program for menopausal symptoms in breast cancer survivors: results from a randomized trial. Supportive Care in Cancer 2009;17:1301-9.

\section{Chandwani 2010 \{published data only\}}

Chandwani KD, Thornton B, Perkins GH, Arun B, Raghuram NV, Nagendra HR, et al. Yoga improves quality of life and benefit finding in women undergoing radiotherapy for breast cancer. Journal of the Society for Integrative Oncology 2010;8(2):43-55.

\section{Chang 2008 \{published data only\}}

Chang P-H, Lai T-H, Shun S-C, Lin L-Y, Chen M-L, Yang Y, et al. Effects of a walking intervention on fatigue-related experiences of hospitalized acute myelogenous leukemia patients undergoing chemotherapy: a randomized controlled trial. Journal of Pain and Symptom Management 2008;35(5):524-34.

\section{Cohen 2004 \{published data only\}}

Cohen L, Warneke C, Fouladi RT, Rodriguez MA, Chaoul-Reich A. Psychological adjustment and sleep quality in a randomized trial of the effects of a Tibetan yoga intervention in patients with lymphoma. Cancer 2004;100:2253-60.
Coleman 2003a \{published data only\}

Coleman EA, Coon S, Hall-Barrow J, Richards K, Gaylor D, Stewart B. Feasibility of exercise during treatment for multiple myeloma. Cancer Nursing 2003;26(5):410-9.

Courneya 2003a \{published data only\}

Courneya KS, Friedenreich CM, Quinney HA, Fields ALA, Jones LW, Fairey AS. A randomized trial of exercise and quality of life in colorectal cancer survivors. European Journal of Cancer Care 2003;12:347-57.

\section{Courneya 2003b \{published data only\}}

Courneya KS, Mackey JR, Bell GJ, Jones LW, Field CJ, Fairey AS. Randomized controlled trial of exercise training in postmenopausal breast cancer survivors: cardiopulmonary and quality of life outcomes. Journal of Clinical Oncology 2003;21:1660-8.

\section{Courneya 2003c \{published data only\}}

Courneya KS, Friedenreich CM, Sela RA, Quinney HA, Rhodes RE, Handman M. The group psychotherapy and home-based physical exercise (group-hope) trial in cancer survivors: physical fitness and quality of life outcomes. Psycho-Oncology 2003;12:357-74.

\section{Courneya 2007a \{published data only\}}

Courneya KS, Friedenrich CM, Reid RD, Gelmon K, Mackey JR, Ladha AB, et al. Predictors of follow-up exercise behavior 6 months after a randomized trial of exercise training during breast cancer chemotherapy. Breast Cancer Research and Treatment 2009;114:179-87.

Courneya KS, McKenzie DC, Reid RD, Mackey JR, Gelmon K, Friedenrich CM, et al. Barriers to supervised exercise training in a randomized controlled trial of breast cancer patients receiving chemotherapy. Annals of Behavioral Medicine 2008;35:116-22.

Courneya KS, Segal RJ, Gelmon K, Reid RD, Mackey JR, Friedenrich CM, et al. Six-month follow-up of patient-rated outcomes in a randomized controlled trial of exercise training during breast cancer chemotherapy. Cancer Epidemiology Biomarkers and Prevention 2007;16(12):2572-8.

* Courneya KS, Segal RJ, Mackey JR, Gelmon K, Reid RD, Friedenreich CM, et al. Effects of aerobic and resistance exercise in breast cancer patients receiving adjuvant chemotherapy: a multicenter randomised controlled trial. Journal of Clinical Oncology 2007;25(28):4396-404.

\section{Courneya 2007b \{published data only\}}

Courneya KS, Friedenrich CM, Reid RD, Gelmon K, Mackey JR, Ladha AB, et al. Predictors of follow-up exercise behavior 6 months after a randomized trial of exercise training during breast cancer chemotherapy. Breast Cancer Research and Treatment 2009;114:179-87.

Courneya KS, McKenzie DC, Reid RD, Mackey JR, Gelmon K, Friedenrich CM, et al. Barriers to supervised exercise training in a randomized controlled trial of breast cancer patients receiving chemotherapy. Annals of Behavioral Medicine 2008;35:116-22. 
Courneya KS, Segal RJ, Gelmon K, Reid RD, Mackey JR, Friedenrich CM, et al. Six-month follow-up of patient-rated outcomes in a randomized controlled trial of exercise training during breast cancer chemotherapy. Cancer Epidemiology Biomarkers and Prevention 2007;16(12):2572-8.

* Courneya KS, Segal RJ, Mackey JR, Gelmon K, Reid RD, Friedenreich CM, et al. Effects of aerobic and resistance exercise in breast cancer patients receiving adjuvant chemotherapy: a multicenter randomised controlled trial. Journal of Clinical Oncology 2007;25:4396-404.

\section{Courneya 2008 \{published data only\}}

Courneya KS, Jones LW, Peddle CJ, Sellar CM, Reiman T, Joy AA, et al. Effects of aerobic exercise training in anemic cancer patients receiving darbepoetin alfa: a randomized controlled trial. The Oncologist 2008;13:1012-20.

\section{Courneya 2009 \{published data only\}}

Courneya KS, Sellar CM, Stevinson C, McNeely ML, Peddle CJ, Friedenreich CM, et al. Randomized controlled trial of the effects of aerobic exercise on physical functioning and quality of life in lymphoma patients. Journal of Clinical Oncology 2009;27(27):4605-12.

\section{Culos-Reed 2006 \{published data only\}}

Culos-Reed SN, Carlson LE, Daroux LM, Hately-Aldous S. A pilot study of yoga for breast cancer survivors: physical and psychological benefits. Psycho-Oncology 2006;15:891-7.

\section{Culos-Reed 2010 \{published data only\}}

Culos-Reed SN, Robinson JW, Lau H, Stephenson L, Keats M, Norris $\mathrm{S}$, et al. Physical activity for men receiving androgen deprivation therapy for prostate cancer: benefits from a 16week intervention. Supportive Care in Cancer 2010;18:591-9.

Daley 2007 \{published and unpublished data\}

Daley AJ, Crank H, Mutrie N, Saxton JM, Coleman R. Determinants of adherence to exercise in women treated for breast cancer. European Journal of Oncology Nursing 2007;11:392-9.

* Daley AJ, Crank H, Saxton JM, Mutrie N, Coleman R, Roalfe A. Randomized trial of exercise therapy in women treated for breast cancer. Journal of Clinical Oncology 2007;25(13):1713-21.

\section{Danhauer 2009 \{published data only\}}

Danhauer SC, Mihalko SL, Russell GB, Campbell CR, Felder L, Daley K, et al. Restorative yoga for women with breast cancer: findings from a randomized pilot study. Psycho-Oncology 2009;18:360-8.

\section{Dimeo 1999 \{published and unpublished data\}}

Dimeo FC, Stieglitz R-D, Novelli-Fischer U, Fetscher S, Keul J. Effects of physical activity on the fatigue and psychologic status of cancer patients during chemotherapy. Cancer 1999;85:2273-7.

\section{Dimeo 2004 \{published and unpublished data\}}

Dimeo FC, Thomas F, Raabe-Menssen C, Pröpper F, Mathias M. Effect of aerobic exercise and relaxation training on fatigue and physical performance of cancer patients after surgery.
A randomised controlled trial. Supportive Care in Cancer 2004;12:774-9.

Dodd 2010a \{published data only\}

Dodd MJ, Cho MH, Miaskowski C, Painter PL, Paul SM, Cooper BA, et al. A randomized controlled trial of home-based exercise for cancer-related fatigue in women during and after chemotherapy with or without radiation therapy. Cancer Nursing 2010;33(4):245-57.

Dodd 2010b \{published data only\}

Dodd MJ, Cho MH, Miaskowski C, Painter PL, Paul SM, Cooper BA, et al. A randomized controlled trial of home-based exercise for cancer-related fatigue in women during and after chemotherapy with or without radiation therapy. Cancer Nursing 2010;33(4):245-57.

\section{Drouin 2005 \{published data only\}}

Drouin JS, Armstrong H, Krause S, Orr J, Birk TJ, Hryniuk WM, et al. Effects of aerobic exercise training on peak aerobic capacity, fatigue, and psychological factors during radiation for breast cancer. Rehabilitation Oncology 2005;23(1):11-7.

Galantino 2003 \{published data only\}

Galantino ML, Capito L, Kane RJ, Ottey N, Switzer S, Packel L. The effects of Tai Chi and walking on fatigue and body mass index in women living with breast cancer: a pilot study. Rehabilitation Oncology 2003;21(1):17-22.

Galvão 2010 \{published data only\}

Galvão DA, Taaffe DR, Spry N, Joseph D, Newton RU. Combined resistance and aerobic exercise program reverses muscle loss in men undergoing androgen suppression therapy for prostate cancer without bone metastases: a randomized controlled trial. Journal of Clinical Oncology 2010;28(2):340-7.

\section{Headley 2004 \{published data only\}}

Headley JA, Ownby KK, John LD. The effect of seated exercise on fatigue and quality of life in women with advanced breast cancer. Oncology Nursing Forum 2004;31(5):977-83.

\section{Heim 2007 \{published data only\}}

Heim ME, vdMalsburg M-LE, Niklas A. Randomized controlled trial of a structured training program in breast cancer patients with tumor-related chronic fatigue. Onkologie 2007;30:429-34.

\section{Hwang 2008 \{published data only\}}

Hwang JH, Chang HJ, Shim YH, Park WH, Huh SJ, Yang J-H. Effects of supervised exercise therapy in patients receiving radiotherapy for breast cancer. Yonsei Medical Journal 2008;49(3):443-50.

\section{Lee 2010 \{published data only\}}

Lee SA, Kang J-Y, Kim YD, An AR, Kim S-W, Kim Y-S, et al. Effects of a scapula-oriented shoulder exercise programme on upper limb dysfunction in breast cancer survivors: a randomized controlled pilot trial. Clinical Rehabilitation 2010;24:600-13. 
McKenzie 2003 \{published data only\}

McKenzie D, Kalda AL. Effect of upper extremity exercise on secondary lymphedema in breast cancer patients: a pilot study. Journal of Clinical Oncology 2003;21(3):463-6.

\section{McNeely 2008 \{published data only\}}

McNeely ML, Parliament MB, Seikaly H, Jha N, Magee DJ, Haykowsky MJ, et al. Effect of exercise on upper extremity pain and dysfunction in head and neck cancer survivors: a randomized controlled trial. Cancer 2008;113:214-22.

\section{Milne 2008 \{published data only\}}

Milne HM, Wallman KE, Gordon S, Courneya KS. Effects of a combined aerobic and resistance exercise program in breast cancer survivors: a randomized controlled trial. Breast Cancer Research and Treatment 2008;108:279-88.

\section{Moadel 2007 \{published data only\}}

Moadel AB, Shah C, Wylie-Rosett J, Harris MS, Patel SR, Hall CB, et al. Randomized controlled trial of yoga among a multiethnic sample of breast cancer patients: effects on quality of life. Journal of Clinical Oncology 2007;25(28):4387-95.

\section{Mock 1994 \{published data only\}}

Mock V, Burke MB, Sheehan P, Creaton EM, Winningham ML, McKenney-Tedder S, et al. A nursing rehabilitation program for women with breast cancer receiving adjuvant chemotherapy. Oncology Nursing Forum 1994;21(5):899-907.

\section{Mock 1997 \{published data only\}}

Mock V, Dow KH, Meares CJ, Grimm PM, Dienemann JA, Haisfield-Wolfe ME, et al. Effects of exercise on fatigue, physical functioning, and emotional distress during radiation therapy for breast cancer. Oncology Nursing Forum 1997;24(6):991-1000.

\section{Mock 2005 \{published data only\}}

Mock V, Frangakis C, Davidson NE, Ropka ME, Pickett M, Poniatowski B, et al. Exercise manages fatigue during breast cancer treatment: a randomised controlled trial. PsychoOncology 2005;14:464-77.

\section{Monga 2007 \{published data only\}}

Monga U, Garber SL, Thornby J, Vallbona C, Kerrigan AJ, Monga TN, et al. Exercise prevents fatigue and improves quality of life in prostate cancer patients undergoing radiotherapy. Archives of Physical Medicine and Rehabilitation 2007;88:1416-22.

\section{Mustian 2009 \{published data only\}}

Mustian KM, Peppone L, Darling TV, Palesh O, Heckler CE, Morrow GR. A 4-week home-based aerobic and resistance exercise program during radiation therapy: a pilot randomized clinical trial. Journal of Supportive Oncology 2009;7(5):158-67.

\section{Mutrie 2007 \{published data only\}}

Mutrie N, Campbell AM, Whyte F, McConnachie A, Emslie C, Lee $L$, et al. Benefits of supervised group exercise programme for women being treated for early stage breast cancer: pragmatic randomised controlled trial. BMJ 2007;334:517-24.

\section{Oh 2008 \{published data only\}}

Oh B, Butow P, Mullan B. Medical Qigong for cancer patients: pilot study of impact on quality of life, side effects of treatment and inflammation. American Journal of Chinese Medicine 2008;36(3):459-72.

\section{Oh 2010 \{published data only\}}

Oh B, Butow P, Mullan B, Clarke S, Beale P, Pavlakis N, et al. Impact of medical Qigong on quality of life, fatigue, mood and inflammation in cancer patients: a randomized controlled trial. Annals of Oncology 2010;21(3):608-14.

Payne 2008 \{published data only\}

Payne JK, Held J, Thorpe J, Shaw H. Effect of exercise on biomarkers, fatigue, sleep disturbances, and depressive symptoms in older women with breast cancer receiving hormonal treatment. Oncology Nursing Forum 2008;35(4):635-42.

\section{Pinto 2003 \{published data only\}}

Pinton BM, Clark MM, Maruyama NC, Feder SI. Psychological and fitness changes associated with exercise participation among women with breast cancer. Psycho-Oncology 2003;12:118-26.

\section{Pinto 2005 \{published data only\}}

* Pinto BM, Frierson GM, Rabin C, Trunzo JJ, Marcus BH. Homebased physical activity intervention for breast cancer patients. Journal of Clinical Oncology 2005;23(15):3577-87.

Pinto BM, Rabin C, Papandonatos GD, Frierson GM, Trunzo JJ, Marcus BH. Maintenance of effects of a home-based physical activity program among breast cancer survivors. Supportive Care in Cancer 2008;16:1279-89.

Rabin C, Pinto, BM, Frierson, GM. Mediators of a randomized controlled physical activity intervention for breast cancer survivors. Journal of Sport and Exercise Psychology 2006;28:269-84.

\section{Rogers 2009 \{published and unpublished data\}}

Rogers LQ, Hopkins-Price P, Vicari S, Markwell S, Pamenter R, Courneya KS, et al. Physical activity and health outcomes three months after completing a physical activity behavior change intervention: persistent and delayed effects. Cancer Epidemiology Biomarkers and Prevention 2009;18(5):1410-8.

* Rogers LQ, Hopkins-Price P, Vicari S, Pamenter R, Courneya S, Markwell S, et al. A randomized trial to increase physical activity in breast cancer survivors. Medicine and Science in Sports and Exercise 2009;41:935-46.

\section{Santa Mina 2012 \{unpublished data only\}}

Santa Mina DS, Ritvo P, Matthew AG, Rampersad A, Stein H, Cheung AM, et al. A pilot randomized trial of group exercise versus personal training for prostate cancer patients receiving androgen deprivation therapy. Unpublished.

Segal 2001a \{published data only\}

Segal R, Evans W, Johnson D, Smith J, Colletta S, Gayton J, et al. Structured exercise improves physical functioning in women 
with stages I and II breast cancer: results of a randomised controlled trial. Journal of Clinical Oncology 2001;19(3):657-65.

\section{Segal 2001b \{published data only\}}

Segal R, Evans W, Johnson D, Smith J, Colletta S, Gayton J, et al. Structured exercise improves physical functioning in women with stages I and II breast cancer: results of a randomised controlled trial. Journal of Clinical Oncology 2001;19(3):657-65.

\section{Segal 2003 \{published data only\}}

Segal RJ, Reid RD, Courneya KS, Malone SC, Parliament MB, Scott CG, et al. Resistance exercise in men receiving androgen deprivation therapy for prostate cancer. Journal of Clinical Oncology 2003;21(9):1653-9.

\section{Segal 2009a \{published data only\}}

Segal RJ, Reid RD, Courneya KS, Sigal RJ, Kenny GP, Prud'Homme DG, et al. Randomized controlled trial of resistance or aerobic exercise in men receiving radiation therapy for prostate cancer. Journal of Clinical Oncology 2009;27(3):344-51.

\section{Segal 2009b \{published data only\}}

Segal RJ, Reid RD, Courneya KS, Sigal RJ, Kenny GP, Prud'Homme DG, et al. Randomized controlled trial of resistance or aerobic exercise in men receiving radiation therapy for prostate cancer. Journal of Clinical Oncology 2009;27(3):344-51.

\section{Sequeira 2012 \{unpublished data only\}}

Sequeira MM, Gomes da Silva M. Exercise program for promotion of physical activity after breast cancer surgery: a randomized and controlled pilot trial. Unpublished.

\section{Shelton 2009 \{published data only\}}

Shleton ML, Lee JQ, Morris S, Massey PR, Kendall DG, Munsell MF, et al. A randomized control trial of a supervised versus a self-directed exercise program for allogenic stem cell transplant patients. Psycho-Oncology 2009;18:353-9.

\section{Thorsen 2005 \{published data only\}}

Thorsen L, Skovlund E, Strømme SB, Hornslien K, Dahl AA, Fosså SD. Effectiveness of physical activity on cardiorespiratory fitness and health-related quality of life in young and middleaged cancer patients shortly after chemotherapy. Journal of Clinical Oncology 2005;23(10):2378-88.

\section{van Weert 2010 \{published data only\}}

van Weert E, May AM, Korstjens I, Post WJ, van der Schans CP, van den Borne B, et al. Cancer-related fatigue and rehabilitation: a randomized controlled multicenter trial comparing physical training combined with cognitivebehavioural therapy with physical training only and with no intervention. Physical Therapy 2010;90(10):1413-25.

\section{Windsor 2004 \{published data only\}}

Windsor PM, Nicol KF, Potter J. A randomized, controlled trial of aerobic exercise for treatment-related fatigue in men receiving radical external beam radiotherapy for localized prostate carcinoma. Cancer 2004;101:550-7.

\section{Yuen 2007a \{published data only\}}

Yuen HK, Sword D. Home-based exercise to alleviate fatigue and improve functional capacity among breast cancer survivors. Journal of Allied Health 2007;36(4):e257-75.

\section{Yuen 2007b \{published data only\}}

Yuen HK, Sword D. Home-based exercise to alleviate fatigue and improve functional capacity among breast cancer survivors. Journal of Allied Health 2007;36(4):e257-75.

\section{References to studies excluded from this review}

Aghili 2007 \{published data only\}

Aghili M, Farhan F, Rade M. A pilot study of the effects of programmed aerobic exercise on the severity of fatigue in cancer patients during external radiotherapy. European Journal of Oncology Nursing 2007;11:179-82.

\section{Barinow-Wojewódzki 2008 \{published data only\}}

Barinow-Wojewódzki A, Laurentowska M, Domaszewska K, Lesiński F, Kaliszewska-Szczepaniak A, Rychlewski T. Effects of rehabilitation on physical efficiency in patients with lung cancer evaluated by means of the 6-minute walking test [Wpływ rehabilitacji ruchowej na wydolność fizyczną pacjentów z rakiem płuc mierzoną 6-minutowym testem marszowym]. Fizjoterapia 2008;16(3):36-47.

\section{Barsevick 2004 \{published data only\}}

Barsevick AM, Dudley W, Beck S, Sweeney C, Whitmer K, Nail L. A randomized clinical trial of energy conservation for patients with cancer-related fatigue. Cancer 2004;100:1302-10.

\section{Battaglini 2007 \{published data only\}}

Battaglini C, Bottaro M, Dennehy C, Rae L, Shields E, Kirk D, et al. The effects of an individualized exercise intervention on body composition in breast cancer patients undergoing treatment. Sao Paulo Medical Journal 2007;125(1):22-8.

\section{Berglund 1994 \{published data only\}}

Berglund G, Bolund C, Gustaffson U-L, Sjödén P-O. A randomized study of a rehabilitation program for cancer patients: the 'starting again' group. Psycho-Oncology 1994;3:109-20.

\section{Buss 2010 \{published data only\}}

Buss T, de Walden-Galuszko K, Modlińska A, Osowicka M, Lichodziejewska-Niemierko M, Janiszewska J. Kinesitherapy alleviates fatigue in terminal hospice cancer patients - an experimental, controlled study. Supportive Care in Cancer 2010;18(6):743-9.

\section{Cella 2004 \{published data only\}}

Cella D, Kallich J, McDemott A, Xu X. The longitudinal relationship of hemoglobin, fatigue and quality of life in anemic cancer patients: results from five randomized clinical trials. Annals of Oncology 2004;15:979-86. 


\section{Coleman 2003b \{published data only\}}

Coleman EA, Hall-Barrow J, Coon S, Stewart CB. Facilitating exercise adherence for patients with multiple myeloma. Clinical Journal of Oncology Nursing 2003;7(5):529-34, 540.

\section{Coleman 2008 \{published data only\}}

Coleman EA, Coon SK, Kennedy RL, Lockhart KD, Stewart CB, Anaissie EJ, et al. Effects of exercise in combination with epoetin alfa during high-dose chemotherapy and autologous peripheral blood stem cell transplantation for multiple myeloma. Oncology Nursing Forum 2008;35(3):E53-61.

\section{Culos-Reed 2007 \{published data only\}}

Culos-Reed SN, Robinson JL, Lau H, O'Connor K, Keats MR. Benefits of a physical activity intervention for men with prostate cancer. Journal of Sport and Exercise Psychology 2007;29(1):118-27.

\section{Decker 1989 \{published data only\}}

Decker WA, Turner-McGlade J, Fehir KM. Psychosocial aspects and the physiological effects of a cardiopulmonary exercise program in patients undergoing bone marrow transplantation (BMT) for acute leukemia (AL). Transplantation Proceedings 1989;21(1):3068-9.

\section{Dimeo 1996 \{published data only\}}

Dimeo F, Bertz H, Finke J, Fetscher S, Mertelsmann R, Keul J. An aerobic exercise program for patients with haematological malignancies after bone marrow transplantation. Bone Marrow Transplantation 1996;18:1157-60.

\section{Dimeo 1997a \{published data only\}}

Dimeo FC, Tilmann MHM, Bertz H, Kanz L, Mertelsmann R, Keul J. Aerobic exercise in the rehabilitation of cancer patients after high dose chemotherapy and autologous peripheral stem cell transplantation. Cancer 1997;79:1717-22.

\section{Dimeo 1997b \{published data only\}}

Dimeo F, Fetscher S, Lange W, Mertelsmann R, Keul J. Effects of aerobic exercise on the physical performance and incidence of treatment-related complications after high dose chemotherapy. Blood 1997;90(9):3390-4.

\section{Dimeo 2008 \{published data only\}}

Dimeo F, Schwartz S, Wessel N, Voigt A, Thiel E. Effects of an endurance and resistance exercise program on persistent cancer-related fatigue after treatment. Annals of Oncology 2008;19(8):1495-9.

\section{Fillion 2008 \{published data only\}}

Fillion L, Gagnon P, Lebland F, Gélinas C, Savard J, Dupuis R, et al. A brief intervention for fatigue management in breast cancer survivors. Cancer Nursing 2008;31(2):145-59.

\section{Goedendorp 2010 \{published data only\}}

Goedendorp MM, Peters MEWJ, Gielissen MFM, Witjes JA, Leer JW, Verhagen CAHHVM, et al. Is increasing physical activity necessary to diminish fatigue during cancer treatment? Comparing cognitive behavior therapy and a brief nursing intervention with usual care in a multicenter randomized controlled trial. The Oncologist 2010;15:1122-32.

\section{Hansen 2009 \{published data only\}}

Hansen PA, Dechet CB, Porucznik CA, LaStayo PC. Comparing eccentric resistance exercise in prostate cancer survivors on and off hormone therapy: a pilot study. Physical Medicine and Rehabilitation 2009;1(11):1019-24.

\section{Hartvig 2006 \{published data only\}}

Hartvig P, Aulin J, Wallenberg S, Wagenius G. Physical exercise for cytotoxic drug induced fatigue. Journal of Oncology Pharmacy Practice 2006;12:183-91.

\section{Hayes 2004 \{published data only\}}

Hayes S, Davies PSW, Parker T, Bashford J, Newman B. Quality of life changes following peripheral blood stem cell transplantation and participation in a mixed-type, moderateintensity, exercise program. Bone Marrow Transplantation 2004;33:553-8.

\section{Hsieh 2008 \{published data only\}}

Hsieh CC, Sprod LK, Hydock DS, Carter SD, Hayward R, Schneider CM. Effects of a supervised exercise intervention on recovery from treatment regimens in breast cancer survivors. Oncology Nursing Forum 2008;35(6):909-15.

Jarden 2009 \{published data only\}

* Jarden M, Baadsgaard MT, Hovgaard DJ, Boesen E, Adamsen $\mathrm{L}$. A randomized trial on the effect of a multimodal intervention on physical capacity, functional performance and quality of life in adult patients undergoing allogenic SCT. Bone Marrow Transplantation 2009;43:725-37.

Jarden M, Nelausen K, Hovgaard D, Boesen E, Adamsen L. The effect of a multimodal intervention on treatment-related symptoms in patients undergoing hematopoietic stem cell transplantation: a randomized controlled trial. Journal of Pain and Symptom Management 2009;38(2):174-90.

Kim 2005 \{published data only\}

Kim SD, Kim HS. Effects of a relaxation breathing exercise on fatigue in haemopoietic stem cell transplantation patients. Journal of Clinical Nursing 2005;14:51-5.

\section{Kim 2009 \{published data only\}}

Kim DJ, Mayo NE, Carli F, Montgomery DL, Zavorsky GS. Responsive measures to prehabilitation in patients undergoing bowel resection surgery. Tohoku Journal of Experimental Medicine 2009;217(2):109-15.

Köhler 2008 \{published data only\}

Köhler N, Damm F, Bauer K, Klee C, Rach S, Lintz D, et al. Supportive effects of moderate physical exercise during cytotoxic/endocrine treatment of breast cancer patients results of a pilot study [Supportive effekte eines moderaten ausdauertrainings während der zytotoxischen/endokrinen therapie von mammakarzinompatientinnen-ergebnisse einer pilotstudie]. Geburtshilfe und Frauenheilkunde 2008;68(8):805-13. 
MacVicar 1989 \{published data only\}

Macvicar MG, Winningham ML, Nickel JL. Effects of aerobic interval training on cancer patients' functional capacity. Nursing Research 1989;38(6):348-51.

\section{Mock 2001 \{published data only\}}

Mock V, Pickett M, Ropka ME, Lin EM, Stewart KJ, Rhodes VA, et al. Fatigue and quality of life outcomes of exercise during cancer treatment. Cancer Practice 2001;9(3):119-27.

\section{Oldervoll 2003 \{published data only\}}

Oldervoll LM, Kaasa S, Knobel H, Loge JH. Exercise reduces fatigue in chronic fatigued Hodgkins disease survivors-results from a pilot study. European Journal of Cancer 2003;39:57-63.

Ozalevli 2010 \{published data only\}

Ozalevli S, Ilgin D, Karaali HK, Bulac S, Akkoclu A. The effect of in-patient chest physiotherapy in lung cancer patients. Supportive Care in Cancer 2010;18(3):351-8.

\section{Pickett 2002 \{published data only\}}

Pickett M, Mock V, Ropka ME, Cameron L, Coleman M, Podewils L. Adherence to moderate-intensity exercise during breast cancer therapy. Cancer Practice 2002;10(6):284-92.

\section{Poorkiani 2010 \{published data only\}}

Poorkiani M, Abbaszadeh A, Hazrati M, Jafari P, Sadeghi M, Mohammadianpanah $M$. The effect of rehabilitation on quality of life in female breast cancer survivors in Iran. Indian Journal of Medical and Paediatric Oncology 2010;31(4):105-9.

\section{Riesenberg 2010 \{published data only\}}

Riesenberg H, Lübbe AS. In-patient rehabilitation of lung cancer patients - a prospective study. Supportive Care in Cancer 2010;18(7):877-82.

\section{Rummans 2006 \{published data only\}}

Cheville AL, Girardi J, Clark MM, Rummans TA, Pittelkow T, Brown $\mathrm{P}$, et al. Therapeutic exercise during outpatient radiation therapy for advanced cancer. American Journal of Physical Medicine and Rehabilitation 2010;89(8):611-9.

* Rummans TA, Clark MM, Sloan JA, Frost MH, Bostwick JM, Atherton PJ, et al. Impacting quality of life for patients with advanced cancer with a structured multidisciplinary intervention: a randomized controlled trial. Journal of Clinical Oncology 2006;24(4):635-42.

\section{Schneider 2007a \{published data only\}}

Schneider CM, Hsieh CC, Sprod LK, Carter SD, Hayward R. Exercise training manages cardiopulmonary function and fatigue during and following cancer treatment in male cancer survivors. Integrative Cancer Therapies 2007;6(3):235-41.

\section{Schneider 2007b \{published data only\}}

Schneider CM, Hsieh CC, Sprod LK, Carter SD, Hayward R. Effects of supervised exercise training on cardiopulmonary function and fatigue in breast cancer survivors during and after treatment. Cancer 2007;110(4):918-25.

\section{Schneider 2007c \{published data only\}}

Schneider CM, Hsieh CC, Sprod LK, Carter SD, Hayward R. Cancer treatment-induced alterations in muscular fitness and quality of life: the role of exercise training. Annals of Oncology 2007;18(12):1957-62.

\section{Schwartz 1999 \{published data only\}}

Schwartz AL. Fatigue mediates the effects of exercise on quality of life. Quality of Life Research 1999;8:529-38.

Schwartz 2000a \{published data only\}

Schwartz AL. Exercise and weight gain in breast cancer patients receiving chemotherapy. Cancer Practice 2000;8(5):231-7.

\section{Schwartz 2000b \{published data only\}}

Schwartz AL. Daily fatigue patterns and effect of exercise in women with breast cancer. Cancer Practice 2000;8(1):16-24.

\section{Schwartz 2001 \{published data only\}}

Schwartz AL, Mori M, Gao R, Nail LM, King ME. Exercise reduces daily fatigue in women with breast cancer receiving chemotherapy. Medicine and Science in Sports and Exercise 2001;33(5):718-23.

\section{Schwartz 2002 \{published data only\}}

Schwartz AL, Thompson JA, Masood N. Interferon-induced fatigue in patients with melanoma: a pilot study of exercise and methylphenidate. Oncology Nursing Forum 2002;29(7):E85-E90.

\section{Sprod 2010 \{published data only\}}

Sprod LK, Hsieh CC, Hayward R, Schneider CM. Three versus six months of exercise training in breast cancer survivors. Breast Cancer Research and Treatment 2010;121(2):413-9.

\section{Turner 2004 \{published data only\}}

Turner J, Hayes S, Reul-Hirche H. Improving the physical status and quality of life of women treated for breast cancer: a pilot study of a structured exercise intervention. Journal of Surgical Oncology 2004;86:141-6.

\section{Vadiraja 2009 \{published data only\}}

Vadiraja HS, Raghavendra RM, Nagarathna R, Nagendra HR, Rekha M, Vanitha N, et al. Effects of a yoga program on cortisol rhythm and mood states in early breast cancer patients undergoing adjuvant radiotherapy: a randomized controlled trial. Integrative Cancer Therapies 2009;8(1):37-46.

Watson 2004 \{published data only\}

Watson T, Mock V. Exercise as an intervention for cancer-related fatigue. Physical Therapy 2004;84(8):736-43.

\section{Wilson 2005 \{published data only\}}

Wilson RW, Jacobsen PB, Fields KK. Pilot study of a home-based aerobic exercise program for sedentary cancer survivors treated with hematopoietic stem cell transplantation. Bone Marrow Transplantation 2005;35:721-7. 


\section{References to ongoing studies}

\section{Fisher-Schlombs 2010 \{published data only\}}

Fisher-Schlombs K, Culos-Reed N, Brandwein J, Minden MD, Tomlinson GA, Alibhai SM. A pilot study of a home-based exercise intervention for adult patients with AML. In: Journal of Clinical Oncology. Vol. 28(15s). 2010:e19570.

\section{Santa Mina 2010 \{published data only\}}

Santa Mina D, Alibhai S, Pirbaglou M, Matthew A, Trachtenberg J, Fleshner N, et al. Aerobic versus resistance exercise training for prostate cancer patients on ADT. In: PsychoOncology. Vol. 19 (Suppl 2). 2010:S196.

\section{Additional references}

\section{Ahlberg 2003}

Ahlberg K, Ekman T, Gaston-Johansson F, Mock V. Assessment and management of cancer-related fatigue in adults. The Lancet 2003;362:640-50.

\section{Al-Majid 2009}

Al-Majid S, Gray DP. A biobehavioral model for the study of exercise interventions in cancer-related fatigue. Biological Research for Nursing 2009;10(4):381-91.

\section{Cella 2002}

Cella D, Eton DT, Lai J-S, Peterman AH, Merkel DE. Combining anchor and distribution-based methods to derive minimal clinically important differences on the functional assessment of cancer therapy (FACT) anemia and fatigue scales. Journal of Pain and Symptom Management 2002;24(6):547-61.

\section{Chodzko-Zajko 2009}

Chodzko-Zajko WJ, Proctor D, Fiatarone Singh M, Minson CT, Nigg CR, Salem GJ, et al. Exercise and physical activity for older adults. Medicine and Science in Sports and Exercise 2009;41(7):1510-30.

\section{Cochrane Pregnancy and Childbirth Group 2012}

Cochrane Pregnancy and Childbirth Group. Author resources for new reviews [updated 24 August 2012]. Available from: http:// pregnancy.cochrane.org/author-resources-new-reviews.

\section{Curt 2000}

Curt GA, Breibart W, Cella D, Groopman JE, Horning SJ, Itri LM, et al. Impact of cancer-related fatigue on the lives of patients: new findings from the fatigue coalition. The Oncologist 2000;5:353-60

\section{Dimeo 2001}

Dimeo FC. Effects of exercise on cancer-related fatigue. Cancer 2001;92:1689-93.

\section{Dimeo 2002}

Dimeo F. Radiotherapy-related fatigue and exercise for cancer patients: a review of the literature and suggestions for future research. Frontiers of Radiation Therapy and Oncology 2002;37:49-56

\section{Fletchner 2002}

Fletchner H, Bottomley A. Fatigue assessment in cancer clinical trials. Experts Reviews in Pharmacoeconomics Outcomes Research 2002;2:67-76.

\section{Garber 2011}

Garber CE, Blissmer B, Deschenes MR, Franklin B, Lamonte MJ, Lee I-M, et al. Quantity and quality of exercise for developing and maintaining cardiorespiratory, musculoskeletal, and neuromuscular fitness in apparently healthy adults: guidance for prescribing exercise. Medicine and Science in Sports and Exercise 2011;43(7):1334-59.

\section{Goedendorp 2009}

Goedendorp MM, Gielissen MFM, Verhagen CAHHVM, Bleijenberg G. Psychosocial interventions for reducing fatigue during cancer treatment in adults. Cochrane Database of Systematic Reviews 2009, Issue 1. Art. No: CD006953. [DOI: 10.1002/14651858.CD006953.pub2]

\section{Higgins 2003}

Higgins J, Thompson S, Deeks J, Altman D. Measuring inconsistency in meta-analysis. British Medical Journal 2003;327:557-60.

\section{Higgins 2011}

Higgins JPT, Green S (editors). Cochrane Handbook for Systematic Reviews of Interventions Version 5.1.0 [updated March 2011]. The Cochrane Collaboration, 2011. Available from www.cochrane-handbook.org.

\section{Jacobsen 2007}

Jacobsen PB, Donovan KA, Vandaparampil ST, Small BJ. Systematic review and meta-analysis of psychological and activity-based interventions for cancer-related fatigue. Health Psychology 2007;26:660-7.

\section{Jadad 1996}

Jadad A, Moore A, Carroll D, Jenkinson C, Reynolds D, Gavaghan D, et al. Assessing the quality of reports of randomized clinical trials: Is blinding necessary. Controlled Clinical Trials 1996;17:1-12.

\section{Lucia 2003}

Lucia A, Earnest C, Perez M. Cancer-related fatigue: can exercise physiology assist oncologists? The Lancet Oncology 2003;4:616-25.

\section{Minton 2010}

Minton O, Richardson A, Sharpe M, Hotopf M, Stone P. Drug therapy for the management of cancer-related fatigue. Cochrane Database of Systematic Reviews 2010, Issue 7. Art. No: CD006704. [DOI: 10.1002/14651858.CD006704.pub3]

\section{Mock 2001b}

Mock V. Fatigue management: evidence and guidelines for practice. Cancer 2001;92:1699-707. 


\section{Montoye 1996}

Montoye HJ, Kemper HCG, Saris WHM, Washburn RA. Measuring Physical Activity and Energy Expenditure. Champaign, Illinois: Human Kinetics, 1996.

\section{Morrow 2001}

Morrow GR, Andrews PLR, Hickok JT, Roscoe JA, Matheson S. Fatigue associated with cancer and its treatment. Supportive Care in Cancer 2001;10:389-98.

\section{Mustian 2007}

Mustian KM, Morrow GR, Carroll JK, Figueroa-Moseley CD, Jean-Pierre P, Williams GC. Integrative non-pharmacological behavioral interventions for the management of cancer-related fatigue. The Oncologist 2007;12(Suppl 1):52-67.

\section{NCCN 2012}

National Comprehensive Cancer Network. Clinical Practice Guidelines in Oncology. Cancer-related fatigue version 1.2012. www.nccn.org (accessed 30 January 2012).

\section{Oldervoll 2004}

Oldervoll LM, Kaasa S, Hjermstad MJ, Lund JA, Loge JH. Physical exercise results in the improved subjective well-being of a few or is effective rehabilitation for all cancer patients? European Journal of Cancer 2004;40:951-62.

\section{Ryan 2007}

Ryan JL, Carroll JK, Ryan EP, Mustian KM, Fiscella K, Morrow GR. Mechanisms of cancer-related fatigue. The Oncologist 2007;12(Suppl 1):22-34

\section{CHARACTERISTICSOFSTUDIES}

Characteristics of included studies [ordered by study ID]

\section{Schmitz 2010}

Schmitz KH, Courneya KS, Matthews C, Demark-Wahnefried W, Galvão DA, Pinto BM, et al. American College of Sports Medicine roundtable on exercise guidelines for cancer. Medicine and Science in Sports and Exercise 2010;42(7):1409-26.

\section{Vallance 2007}

Vallance JKH, Courneya KS, Plotnikoff RC, Yasui Y, Mackey JR. Randomized controlled trial of the effects of print materials and step pedometers on physical activity and quality of life in breast cancer survivors. Journal of Clinical Oncology 2007;25(17):2352-9.

\section{Wagner 2004}

Wagner L, Cella D. Fatigue and cancer: causes, prevalence and treatment approaches. British Journal of Cancer 2004;91(5):822-8.

\section{Winningham 1992}

Winningham ML. How exercise mitigates fatigue: implications for people receiving cancer therapy. In: Johnson RM, editors(s). The Biotherapy of Cancer V. Pittsburgh: Oncology Nursing Press, 1992:16-20.

\section{References to other published versions of this review Cramp 2008}

Cramp F, Daniel J. Exercise for the management of cancer-related fatigue in adults. Cochrane Database of Systematic Reviews 2008, Issue 2. Art. No: CD006145. [DOI: 10.1002/14651858.CD006145.pub2]

* Indicates the major publication for the study

Adamsen 2009

\section{Study characteristics}

\begin{tabular}{ll}
\hline Methods & RCT; 2 group parallel design \\
\hline Participants & $\begin{array}{l}235 \text { participants with } 21 \text { different cancer diagnoses, median of } 84 \text { days since diagnosis, were receiving } \\
\text { chemotherapy }\end{array}$ \\
\hline Interventions & $\begin{array}{l}\text { Multimodal supervised groups; aerobic, resistance and relaxation/body awareness. } 6 \text { weeks with } 4 \text { ses- } \\
\text { sions/week (24 total), } 9 \text { hours/week. } \\
\text { Control: usual care }\end{array}$ \\
\hline Outcomes & Fatigue \\
& QoL \\
Side effects \\
Aerobic capacity \\
Muscle strength
\end{tabular}


Adamsen 2009 (Continued)

Leisure time physical activity

Notes Methodological quality score: 3

Main purpose of exercise: fatigue was the primary outcome

\section{Risk of bias}

\begin{tabular}{lll}
\hline Bias & Authors' judgement & Support for judgement \\
\hline $\begin{array}{l}\text { Random sequence genera- } \\
\text { tion (selection bias) }\end{array}$ & Low risk & "Randomisation was done by computer" \\
\hline $\begin{array}{l}\text { Allocation concealment } \\
\text { (selection bias) }\end{array}$ & Low risk & $\begin{array}{l}\text { "The allocation sequence was executed by the clinical research unit and con- } \\
\text { cealed from the project team." }\end{array}$ \\
\hline $\begin{array}{l}\text { Blinding of outcome as- } \\
\text { sessment (detection bias) } \\
\text { All outcomes }\end{array}$ & High risk & Blinding not done \\
\hline $\begin{array}{l}\text { Incomplete outcome data } \\
\text { (attrition bias) } \\
\text { All outcomes }\end{array}$ & Low risk & All patients were accounted for \\
\hline $\begin{array}{l}\text { Selective reporting (re- } \\
\text { porting bias) }\end{array}$ & Low risk & Fatigue outcome reported \\
\hline
\end{tabular}

Battaglini 2008

\section{Study characteristics}

\begin{tabular}{ll}
\hline Methods & RCT; 2-group parallel design \\
\hline Participants & 20 breast cancer patients due to receive adjuvant therapy \\
\hline Interventions & $\begin{array}{l}\text { Aerobic and resistance training at } 40 \% \text { to } 60 \% \text { maximum exercise capacity and stretching; twice per } \\
\text { week for } 15 \text { weeks, up to } 60 \text { minutes per session } \\
\text { Control: usual care }\end{array}$ \\
\hline Outcomes & Fatigue \\
& Total caloric intake \\
& Cardiovascular endurance \\
& Dynamic muscular endurance \\
Body composition \\
\hline Risk of bias & Methodological quality score: 1 \\
\hline Main purpose of exercise: total calorie intake & \\
\hline
\end{tabular}


Battaglini 2008 (Continued)

Random sequence genera- Unclear risk Stated to be randomised
tion (selection bias)

Allocation concealment $\quad$ Unclear risk $\quad$ Not stated
(selection bias)

(selection bias)

$\begin{array}{lll}\text { Blinding of outcome as- } & \text { High risk } & \text { Blinding not done } \\ \text { sessment (detection bias) } & & \end{array}$

All outcomes

Incomplete outcome data Unclear risk Not clear if all participants completed the study
(attrition bias)
All outcomes

Selective reporting (re- Low risk $\quad$ Fatigue outcome reported
porting bias)

Brown 2006

\section{Study characteristics}

\begin{tabular}{ll}
\hline Methods & $\begin{array}{l}\text { RCT; } 2 \text { groups, stratification by tumour type, age, gender and Eastern Co-operative Oncology Group } \\
\text { Score }\end{array}$ \\
\hline Participants & 103 cancer patients diagnosed within past 12 months and due to receive radiotherapy \\
\hline Interventions & $\begin{array}{l}\text { Structured multidisciplinary sessions incorporating self paced exercise. } 8 \text { sessions over } 4 \text { weeks with } 20 \\
\text { mins of exercise per session. Control: usual care }\end{array}$ \\
\hline Outcomes & $\begin{array}{l}\text { Fatigue } \\
\text { Mood } \\
\text { Anxiety }\end{array}$
\end{tabular}

\begin{tabular}{ll}
\hline Notes & Methodological quality score: 1 \\
& Main purpose of exercise: to improve quality of life
\end{tabular}

\section{Risk of bias}

\begin{tabular}{lll}
\hline Bias & Authors' judgement & Support for judgement \\
\hline $\begin{array}{l}\text { Random sequence genera- } \\
\text { tion (selection bias) }\end{array}$ & Unclear risk & "randomly assigned" but methods not described \\
\hline $\begin{array}{l}\text { Allocation concealment } \\
\text { (selection bias) }\end{array}$ & Unclear risk & Not stated \\
\hline $\begin{array}{l}\text { Blinding of outcome as- } \\
\text { sessment (detection bias) } \\
\text { All outcomes }\end{array}$ & High risk & Blinding not done \\
\hline $\begin{array}{l}\text { Incomplete outcome data } \\
\text { (attrition bias) } \\
\text { All outcomes }\end{array}$ & High risk & $\begin{array}{l}\text { Drop-outs not accounted for and unclear whether an intention-to-treat analy- } \\
\text { sis was undertaken }\end{array}$ \\
\hline
\end{tabular}


Brown 2006 (Continued)
Selective reporting (re-
Low risk
Fatigue outcome reported porting bias)

Burnham 2002

\section{Study characteristics}

\begin{tabular}{ll}
\hline Methods & RCT; 3 groups, stratification by aerobic capacity and quality of life \\
\hline Participants & 21 breast or prostate cancer survivors minimum 2 months post-treatment \\
\hline Interventions & Moderate-intensity exercise: $40 \%$ to $50 \%$ HR reserve rising to $60 \%$ by week 10 \\
& Low-intensity exercise: $25 \%$ to $35 \%$ HR rising to $40 \%$ by week 10 \\
& Both groups supervised exercise 3 times/week for 10 weeks. Sessions initially 14 minutes increasing to \\
& 32 by week 10. Treadmill, stationary bicycle and stair climbing. \\
& Control: no exercise prescribed \\
\hline Outcomes & Aerobic capacity \\
& Body composition \\
& Flexibility \\
Quality of life & Fatigue \\
Anxiety \\
Confusion \\
Depression \\
Energy \\
Anger \\
\end{tabular}

$\begin{array}{ll}\text { Notes } & \text { Methodological quality score: } 2 \\ & \text { Main purpose of exercise: to improve physiological and psychological function }\end{array}$

\section{Risk of bias}

\begin{tabular}{lll}
\hline Bias & Authors' judgement & Support for judgement \\
\hline $\begin{array}{l}\text { Random sequence genera- } \\
\text { tion (selection bias) }\end{array}$ & Unclear risk & "randomly assigned" but no method described \\
\hline $\begin{array}{l}\text { Allocation concealment } \\
\text { (selection bias) }\end{array}$ & Unclear risk & Not stated \\
\hline $\begin{array}{l}\text { Blinding of outcome as- } \\
\text { sessment (detection bias) } \\
\text { All outcomes }\end{array}$ & High risk & Blinding not done \\
\hline $\begin{array}{l}\text { Incomplete outcome data } \\
\text { (attrition bias) } \\
\text { All outcomes }\end{array}$ & High risk & Intention-to-treat not applied as one participant from the control arm was ex- \\
\hline $\begin{array}{l}\text { Selective reporting (re- } \\
\text { porting bias) }\end{array}$ & Low risk & Fluded as they took part in exercise training. \\
\hline
\end{tabular}


Campbell 2005

\section{Study characteristics}

\begin{tabular}{|c|c|c|}
\hline Methods & \multicolumn{2}{|c|}{ RCT; 2 groups, stratification by type of adjuvant cancer therapy } \\
\hline Participants & \multicolumn{2}{|c|}{$\begin{array}{l}22 \text { breast cancer patients post-surgery, receiving therapy. Not exercising vigorously } 3 \text { times/week for } 20 \\
\text { mins or more }\end{array}$} \\
\hline Interventions & \multicolumn{2}{|c|}{$\begin{array}{l}\text { Exercise: supervised, } 2 \text { times/week for } 12 \text { weeks. Warm up, } 10 \text { to } 20 \text { mins of various exercises, cool } \\
\text { down. Approximate } 60 \% \text { to } 75 \% \text { age-adjusted HRmax. } \\
\text { Control: no intervention until week } 12\end{array}$} \\
\hline Outcomes & \multicolumn{2}{|l|}{$\begin{array}{l}\text { Quality of life } \\
\text { Fatigue } \\
\text { Physical activity levels }\end{array}$} \\
\hline Notes & \multicolumn{2}{|c|}{$\begin{array}{l}\text { Methodological quality score: } 3 \\
\text { Main purpose of exercise: to improve quality of life }\end{array}$} \\
\hline \multicolumn{3}{|l|}{ Risk of bias } \\
\hline Bias & Authors' judgement & Support for judgement \\
\hline $\begin{array}{l}\text { Random sequence genera- } \\
\text { tion (selection bias) }\end{array}$ & Low risk & "randomly allocated by computer-generated numbers" \\
\hline $\begin{array}{l}\text { Allocation concealment } \\
\text { (selection bias) }\end{array}$ & Unclear risk & Not stated \\
\hline $\begin{array}{l}\text { Blinding of outcome as- } \\
\text { sessment (detection bias) } \\
\text { All outcomes }\end{array}$ & High risk & Blinding not done \\
\hline $\begin{array}{l}\text { Incomplete outcome data } \\
\text { (attrition bias) } \\
\text { All outcomes }\end{array}$ & Low risk & All participants were accounted for \\
\hline $\begin{array}{l}\text { Selective reporting (re- } \\
\text { porting bias) }\end{array}$ & Low risk & Fatigue outcome reported \\
\hline
\end{tabular}

\section{Carson 2009}

\section{Study characteristics}

\begin{tabular}{ll}
\hline Methods & RCT; 2 groups, wait list control \\
\hline Participants & $\begin{array}{l}37 \text { breast cancer patients, diagnosed at least } 2 \text { years previously. Had received a variety of adjuvant } \\
\text { treatments. }\end{array}$ \\
\hline Interventions & $\begin{array}{l}\text { Exercise: yoga; supervised in groups (5 to } 10 \text { per group) for } 120 \text { minutes once/week for } 8 \text { weeks, and en- } \\
\text { couraged to practise daily with CD and illustrated handbook }\end{array}$ \\
& Control: wait list, received usual care \\
\hline Outcomes & Fatigue \\
& Hot flashes \\
\hline
\end{tabular}


Carson 2009 (Continued)

$$
\begin{aligned}
& \text { Joint pain } \\
& \text { Mood }
\end{aligned}
$$

Sleep disturbance

Bother

\begin{tabular}{ll}
\hline Notes & Methodological quality score: 3 \\
Main purpose of exercise: to reduce hot flashes
\end{tabular}

\section{Risk of bias}

\section{Bias}

Authors' judgement Support for judgement

Random sequence genera- Low risk "Randomization...random number table"

tion (selection bias)

\begin{tabular}{|c|c|c|}
\hline $\begin{array}{l}\text { Blinding of outcome as- } \\
\text { sessment (detection bias) }\end{array}$ & Unclear risk & $\begin{array}{l}\text { "The research assistant collecting assessment data was kept blind with regard } \\
\text { to patient condition assignments". Fatigue was self report. }\end{array}$ \\
\hline
\end{tabular}

\begin{tabular}{ll}
\hline $\begin{array}{l}\text { Allocation concealment } \\
\text { (selection bias) }\end{array}$ & Low risk \\
& tients had completed their baseline assessment."
\end{tabular}

All outcomes to patient condition assignments". Fatigue was self report.

Incomplete outcome data Low risk All patients were accounted for
(attrition bias)

All outcomes

Selective reporting (re- Low risk $\quad$ Fatigue outcome reported
porting bias)
porting bias)

Chandwani 2010

\section{Study characteristics}

\begin{tabular}{ll}
\hline Methods & RCT; 2 groups, wait list control \\
\hline Participants & 58 breast cancer patients, due to receive radiotherapy \\
\hline Interventions & $\begin{array}{l}\text { Exercise: yoga; } 2 \times 60 \text { min classes/week for } 6 \text { weeks, supervised, mainly on a one to one basis. Encour- } \\
\text { aged to practice daily. } \\
\text { Control: wait list, received usual care }\end{array}$ \\
\hline Outcomes & Quality of life (SF36 provided vitality data) \\
& Depression \\
& Anxiety \\
& Sleep disturbance \\
& Tendency to ruminate \\
& Finding meaning in cancer \\
\hline Notes & Methodological quality score: 2 \\
\hline
\end{tabular}


Chandwani 2010 (Continued)

Main purpose of exercise: to improve quality of life

\section{Risk of bias}

\begin{tabular}{|c|c|c|}
\hline Bias & Authors' judgement & Support for judgement \\
\hline $\begin{array}{l}\text { Random sequence genera- } \\
\text { tion (selection bias) }\end{array}$ & Unclear risk & "randomly assigned" but process not clear \\
\hline $\begin{array}{l}\text { Allocation concealment } \\
\text { (selection bias) }\end{array}$ & Unclear risk & Not stated \\
\hline $\begin{array}{l}\text { Blinding of outcome as- } \\
\text { sessment (detection bias) } \\
\text { All outcomes }\end{array}$ & High risk & Blinding not done \\
\hline $\begin{array}{l}\text { Incomplete outcome data } \\
\text { (attrition bias) } \\
\text { All outcomes }\end{array}$ & Low risk & All participants were accounted for \\
\hline $\begin{array}{l}\text { Selective reporting (re- } \\
\text { porting bias) }\end{array}$ & Low risk & Fatigue outcome reported \\
\hline
\end{tabular}

\section{Chang 2008}

\section{Study characteristics}

\begin{tabular}{ll}
\hline Methods & RCT; 2 groups, parallel design \\
\hline Participants & 22 patients with acute myelogenous leukaemia, due to commence chemotherapy \\
\hline Interventions & $\begin{array}{l}\text { Exercise: walking exercise programme during inpatient CT, } 12 \text { minutes of supervised walking on } 5 \text { days/ } \\
\text { week for } 3 \text { weeks. Aimed to reach a target intensity of resting heart rate plus } 30 . \\
\text { Control: attention control, no additional intervention specific to fatigue }\end{array}$ \\
\hline
\end{tabular}

\begin{tabular}{ll}
\hline Outcomes & Fatigue \\
& Walk distance \\
& Symptom distress \\
& Mood (including anxiety and depression) \\
\hline Notes & Methodological quality score: 2 \\
& Main purpose of exercise: to reduce fatigue \\
\hline
\end{tabular}

\section{Risk of bias}

\begin{tabular}{lll}
\hline Bias & Authors' judgement & Support for judgement \\
\hline $\begin{array}{l}\text { Random sequence genera- } \\
\text { tion (selection bias) }\end{array}$ & Unclear risk & "randomized" but method not stated \\
\hline $\begin{array}{l}\text { Allocation concealment } \\
\text { (selection bias) }\end{array}$ & Unclear risk & Allocation not stated \\
\hline
\end{tabular}


Chang 2008 (Continued)

$\begin{array}{lll}\text { Blinding of outcome as- } & \text { High risk } & \text { Blinding not done } \\ \text { sessment (detection bias) } & \end{array}$

All outcomes

\begin{tabular}{lll}
\hline $\begin{array}{l}\text { Incomplete outcome data } \\
\text { (attrition bias) }\end{array}$ & Low risk & All participants were accounted for \\
All outcomes & \\
\hline $\begin{array}{l}\text { Selective reporting (re- } \\
\text { porting bias) }\end{array}$ & Low risk & Fatigue outcome reported \\
\hline
\end{tabular}

\section{Cohen 2004}

\section{Study characteristics}

\begin{tabular}{ll}
\hline Methods & CCT; 2 groups \\
\hline Participants & 39 lymphoma patients either during treatment or up to 12 months post-treatment \\
\hline Interventions & Exercise: yoga class once per week for 7 weeks. \\
& Control: wait list \\
\hline Outcomes & Distress \\
& Anxiety \\
& Depression \\
& Fatigue \\
& Sleep disturbance \\
\hline Notes & Methodological quality score: 0 \\
& Main purpose of exercise: to reduce stress \\
\hline
\end{tabular}

\section{Risk of bias}

Bias Authors' judgement Support for judgement

Random sequence genera- High risk "Group assignment was conducted sequentially using minimization" tion (selection bias)

\begin{tabular}{lll}
\hline $\begin{array}{l}\text { Allocation concealment } \\
\text { (selection bias) }\end{array}$ & Low risk & $\begin{array}{l}\text { "The allocation process was concealed from all investigators because all the } \\
\text { relevant information was entered into a computer program and group assign- } \\
\text { ment was determined by the program." }\end{array}$ \\
\hline $\begin{array}{l}\text { Blinding of outcome as- } \\
\text { sessment (detection bias) } \\
\begin{array}{l}\text { All outcomes } \\
\text { Incomplete outcome data }\end{array}\end{array}$ & High risk & Blinding not done \\
$\begin{array}{l}\text { (attrition bias) } \\
\text { All outcomes }\end{array}$ & Low risk & $\begin{array}{l}\text { 1 participant dropped out of the study, no data were available for the individ- } \\
\text { ual antention-to-treat analysis was not undertaken }\end{array}$ \\
\hline $\begin{array}{l}\text { Selective reporting (re- } \\
\text { porting bias) }\end{array}$ & Fatigue outcome reported \\
\hline
\end{tabular}


Coleman 2003a

\section{Study characteristics}

\begin{tabular}{ll}
\hline Methods & RCT; 2 groups \\
\hline Participants & $\begin{array}{l}24 \text { multiple myeloma patients receiving high-dose chemotherapy and tandem peripheral blood stem } \\
\text { cell transplantation }\end{array}$ \\
\hline Interventions & $\begin{array}{l}\text { Exercise: individualised home-based programme of strength and aerobic training } \\
\text { Control: no individual programme, advised to remain active and walk for } 20 \text { mins at least } 3 \text { times/week }\end{array}$ \\
\hline Outcomes & $\begin{array}{l}\text { Fatigue } \\
\text { Mood disturbance } \\
\text { Sleep variables } \\
\text { Body composition } \\
\text { Strength } \\
\text { Aerobic capacity }\end{array}$ \\
\end{tabular}

$\begin{array}{ll}\text { Notes } & \text { Methodological quality score: } 2 \\ & \text { Main purpose of exercise: to improve fatigue and sleep }\end{array}$

\section{Risk of bias}

\begin{tabular}{lll}
\hline Bias & Authors' judgement & Support for judgement \\
\hline $\begin{array}{l}\text { Random sequence genera- } \\
\text { tion (selection bias) }\end{array}$ & Unclear risk & "randomly assigned" but method of sequence generation not described \\
\hline $\begin{array}{l}\text { Allocation concealment } \\
\text { (selection bias) }\end{array}$ & Unclear risk & $\begin{array}{l}\text { "having a research assistant draw a sealed envelope containing group assign- } \\
\text { ment", envelope not described as 'opaque' }\end{array}$ \\
\hline $\begin{array}{l}\text { Blinding of outcome as- } \\
\text { sessment (detection bias) } \\
\text { All outcomes }\end{array}$ & High risk & Blinding not done \\
\hline $\begin{array}{l}\text { Incomplete outcome data } \\
\begin{array}{l}\text { (attrition bias) } \\
\text { All outcomes }\end{array}\end{array}$ & Unclear risk & $\begin{array}{l}\text { Not all participants accounted for and not clear whether intention-to-treat } \\
\text { analysis was undertaken }\end{array}$ \\
\hline $\begin{array}{l}\text { Selective reporting (re- } \\
\text { porting bias) }\end{array}$ & Low risk & Fatigue outcome reported \\
\hline
\end{tabular}

Courneya 2003a

\section{Study characteristics}

\begin{tabular}{ll}
\hline Methods & RCT (wait list control); 2 groups \\
\hline Participants & 102 colorectal cancer survivors following surgery within past 3 months \\
\hline Interventions & $\begin{array}{l}\text { Exercise: personalised home-based cardiovascular and flexibility programme lasting } 16 \text { weeks. Re- } \\
\text { ceived a weekly phone call. } \\
\text { Control: no intervention, requested not to commence a structured exercise programme }\end{array}$ \\
\hline Outcomes & $\begin{array}{l}\text { Quality of life } \\
\text { Fatigue } \\
\text { Depression }\end{array}$ \\
\hline
\end{tabular}


Courneya 2003a (Continued)

\section{Anxiety}

Cardiovascular fitness

Body composition

Flexibility

$\begin{array}{ll}\text { Notes } & \text { Methodological quality score: } 3 \\ & \text { Main purpose of exercise: to improve quality of life }\end{array}$

\section{Risk of bias}

Bias

Authors' judgement Support for judgement

Random sequence genera- Low risk tion (selection bias)

"participants were randomly assigned to an exercise group or wait-list control group using a random-numbers table"

\begin{tabular}{l}
$\begin{array}{l}\text { Allocation concealment } \\
\text { (selection bias) }\end{array} \quad$ Unclear risk $\quad$ Allocation not stated \\
\hline
\end{tabular}

Blinding of outcome as- High risk Blinding not done

sessment (detection bias)

All outcomes

Incomplete outcome data Low risk $\quad$ All participants were accounted for
(attrition bias)

All outcomes

\begin{tabular}{l}
$\begin{array}{l}\text { Selective reporting (re- } \\
\text { porting bias) }\end{array}$ Low risk $\quad$ Fatigue outcome reported \\
\hline
\end{tabular}

\section{Courneya 2003b}

\section{Study characteristics}

\begin{tabular}{ll}
\hline Methods & RCT; 2 groups, stratification by type of adjuvant cancer therapy \\
\hline Participants & 53 breast cancer patients post anti-cancer treatment \\
\hline Interventions & Exercise: supervised cardiovascular programme using cycle ergometers. 3 sessions/week for 15 weeks. \\
& $\begin{array}{l}\text { Intensity - } 70 \% \text { to } 75 \% \text { max oxygen consumption. Time increased from } 15 \text { mins to } 35 \text { mins with } 5 \text { mins } \\
\text { warm up and cool down. } \\
\text { Control: no intervention }\end{array}$ \\
\hline Outcomes & Peak oxygen consumption and secondary cardiopulmonary outcomes \\
& Quality of life \\
& Happiness \\
Self esteem & Fatigue \\
Body composition
\end{tabular}

$\begin{array}{ll}\text { Notes } & \text { Methodological quality score: } 3 \\ & \text { Main purpose of exercise: to improve cardiopulmonary function and quality of life }\end{array}$

\section{Risk of bias}




\section{Courneya 2003b (Continued)}

Random sequence genera- Low risk "randomly assigned to the exercise or control group using a random-numbers tion (selection bias) table"

\begin{tabular}{|c|c|c|}
\hline $\begin{array}{l}\text { Allocation concealment } \\
\text { (selection bias) }\end{array}$ & Unclear risk & $\begin{array}{l}\text { "allocation sequence and group assignments were generated by a research as- } \\
\text { sistant and then enclosed in sequentially numbered and sealed envelopes" - } \\
\text { unclear as not stated as 'opaque' }\end{array}$ \\
\hline
\end{tabular}

Blinding of outcome as- Unclear risk Outcome assessors were blind to group allocation but fatigue was self report sessment (detection bias)

All outcomes

\section{Incomplete outcome data Low risk} (attrition bias)

All outcomes

Selective reporting (re- Low risk $\quad$ Fatigue outcome reported
porting bias)

\section{Courneya 2003c}

\section{Study characteristics}

\begin{tabular}{ll}
\hline Methods & RCT; 2 groups, groups stratified for content \\
\hline Participants & 108 cancer survivors with various diagnoses \\
\hline Interventions & Exercise: group psychotherapy plus individualised home-based cardiovascular and flexibility exercises. \\
& 3 to 5 times/week for 20 to 30 mins at 65 to $75 \%$ HRmax. \\
& Control: group psychotherapy only \\
& Both groups 10 weeks \\
\hline Outcomes & Quality of life \\
& Satisfaction with life \\
& Depression \\
& Anxiety \\
& Fatigue \\
Cardiovascular fitness \\
Body composition \\
Flexibility \\
Physical activity levels
\end{tabular}

$\begin{array}{ll}\text { Notes } & \text { Methodological quality score: } 3 \\ & \text { Main purpose of exercise: to improve quality of life }\end{array}$

\section{Risk of bias}

\begin{tabular}{lll}
\hline Bias & Authors' judgement & Support for judgement \\
\hline $\begin{array}{l}\text { Random sequence genera- } \\
\text { tion (selection bias) }\end{array}$ & Low risk & $\begin{array}{l}\text { "classes were randomized to experimental conditions using a random num- } \\
\text { bers table" }\end{array}$ \\
\hline $\begin{array}{l}\text { Allocation concealment } \\
\text { (selection bias) }\end{array}$ & Unclear risk & Not stated \\
\hline $\begin{array}{l}\text { Blinding of outcome as- } \\
\text { sessment (detection bias) }\end{array}$ & High risk & Blinding not done \\
\hline
\end{tabular}


Courneya 2003c (Continued)

All outcomes

$\begin{array}{ll}\text { Incomplete outcome data } & \text { Unclear risk } \\ \text { (attrition bias) } & \begin{array}{l}12 \text { participants did not complete the study or provide post-test data and were } \\ \text { not included in intention-to-treat analysis }\end{array}\end{array}$

All outcomes

not included in intention-to-treat analysis

Selective reporting (re- Low risk $\quad$ Fatigue outcome reported
porting bias)

\section{Courneya 2007a}

\section{Study characteristics}

\begin{tabular}{ll}
\hline Methods & RCT; 3 groups, stratified by treatment centre and chemotherapy protocol \\
\hline Participants & 242 women with breast cancer initiating chemotherapy \\
\hline Interventions & Aerobic exercise: supervised 3 times/week during chemotherapy. Resistance exercise: supervised 3 \\
& times/week during chemotherapy. Control: usual care \\
\hline Outcomes & Quality of life \\
& Fatigue \\
Anxiety & Depression \\
Self esteem & Physical fitness \\
Body composition \\
Chemotherapy completion rate \\
Lymphoedema
\end{tabular}

Notes

Methodological quality score: 2

Main purpose of exercise: to improve quality of life

\section{Risk of bias}

\begin{tabular}{|c|c|c|}
\hline Bias & Authors' judgement & Support for judgement \\
\hline $\begin{array}{l}\text { Random sequence genera- } \\
\text { tion (selection bias) }\end{array}$ & Low risk & "randomly assigned...using a computer generated program" \\
\hline $\begin{array}{l}\text { Allocation concealment } \\
\text { (selection bias) }\end{array}$ & Low risk & $\begin{array}{l}\text { "The allocation sequence was...concealed from the project directors at each } \\
\text { site who assigned participants to groups" }\end{array}$ \\
\hline $\begin{array}{l}\text { Blinding of outcome as- } \\
\text { sessment (detection bias) } \\
\text { All outcomes }\end{array}$ & High risk & Blinding not done \\
\hline $\begin{array}{l}\text { Incomplete outcome data } \\
\text { (attrition bias) } \\
\text { All outcomes }\end{array}$ & Low risk & All participants were accounted for \\
\hline $\begin{array}{l}\text { Selective reporting (re- } \\
\text { porting bias) }\end{array}$ & Low risk & Fatigue outcome reported \\
\hline
\end{tabular}


Courneya 2007b

\section{Study characteristics}

\begin{tabular}{lc}
\hline Methods & see Courneya 2007a \\
\hline Participants & see Courneya 2007a \\
\hline Interventions & see Courneya 2007a \\
\hline Outcomes & see Courneya 2007a \\
\hline Notes & see Courneya 2007a
\end{tabular}

\section{Risk of bias}

Bias Authors' judgement Support for judgement

Random sequence genera- Low risk "randomly assigned...using a computer generated program" tion (selection bias)

\begin{tabular}{ll}
\hline $\begin{array}{l}\text { Allocation concealment } \quad \text { Low risk } \\
\text { (selection bias) }\end{array}$ & "The allocation sequence was...concealed from the project directors at each \\
site who assigned participants to groups"
\end{tabular}

Blinding of outcome as- High risk Blinding not done

sessment (detection bias)

All outcomes

\begin{tabular}{lll}
\hline $\begin{array}{l}\text { Incomplete outcome data } \\
\text { (attrition bias) }\end{array}$ & Low risk & \\
$\begin{array}{l}\text { All outcomes } \\
\text { Selective reporting (re- }\end{array}$ & Low risk & Fatigue outcome reported \\
\hline \begin{tabular}{l} 
porting bias) \\
\hline
\end{tabular}
\end{tabular}

\section{Courneya 2008}

\section{Study characteristics}

\begin{tabular}{ll}
\hline Methods & RCT; 2 groups, parallel design \\
\hline Participants & 55 patients with non-myeloid cancer, receiving darbepoetin alfa therapy for anaemia \\
\hline Interventions & $\begin{array}{l}\text { Exercise: darbepoetin alfa plus individually tailored exercise programme to improve cardiorespiratory } \\
\text { fitness. } 3 \text { supervised cycle ergometry sessions/week for } 12 \text { weeks. Intensity } 60 \% \text { to } 100 \% \text { baseline peak } \\
\text { power output. }\end{array}$ \\
& $\begin{array}{l}\text { Control: darbepoetin alfa as per exercise group. Requested not to commence exercise programme dur- } \\
\text { ing intervention period. }\end{array}$ \\
\hline Outcomes & Fatigue \\
Quality of life & Aerobic capacity \\
Haemoglobin
\end{tabular}


Courneya 2008 (Continued)
Notes
Methodological quality score: 2
Main purpose of exercise: to improve cardiorespiratory fitness

\section{Risk of bias}

\begin{tabular}{|c|c|c|}
\hline Bias & Authors' judgement & Support for judgement \\
\hline $\begin{array}{l}\text { Random sequence genera- } \\
\text { tion (selection bias) }\end{array}$ & Low risk & $\begin{array}{l}\text { "randomly assigned to either DAL or DEX in a 1:1 ratio using a computer gener- } \\
\text { ated program." }\end{array}$ \\
\hline $\begin{array}{l}\text { Allocation concealment } \\
\text { (selection bias) }\end{array}$ & Low risk & $\begin{array}{l}\text { "The allocation sequence was concealed from the project director who as- } \\
\text { signed participants to groups." }\end{array}$ \\
\hline $\begin{array}{l}\text { Blinding of outcome as- } \\
\text { sessment (detection bias) } \\
\text { All outcomes }\end{array}$ & Unclear risk & "Oncologists to group assignments" but self reported fatigue \\
\hline $\begin{array}{l}\text { Incomplete outcome data } \\
\text { (attrition bias) } \\
\text { All outcomes }\end{array}$ & Low risk & All participants were accounted for \\
\hline $\begin{array}{l}\text { Selective reporting (re- } \\
\text { porting bias) }\end{array}$ & Low risk & Fatigue outcome reported \\
\hline
\end{tabular}

Courneya 2009

\section{Study characteristics}

\begin{tabular}{ll}
\hline Methods & RCT; 2 groups, parallel design \\
\hline Participants & $\begin{array}{l}122 \text { patients with Hodgkin's or non-Hodgkin's lymphoma, 44\% receiving adjuvant therapy, 56\% post- } \\
\text { adjuvant therapy }\end{array}$ \\
\hline
\end{tabular}

Interventions Exercise: aerobic on a cycle ergometer; supervised, 3 times/week for 12 weeks. 15 to 20 mins for first 4 weeks then increased by 5 mins/week to 40 to 45 mins in week 9 . In week 7 interval training above ventilatory threshold was introduced. Week $9 \mathrm{VO}_{2}$ peak training introduced. Intensity: commenced at $60 \%$ of peak power output, increased by $5 \%$ each week to a maximum of $75 \%$ by week 4 .

Control: usual care, asked not to exercise above baseline

\begin{tabular}{ll}
\hline Outcomes & Fatigue \\
& Physical function \\
& Quality of life \\
Happiness & Depression \\
Anxiety & Lymphoma symptoms \\
Cardiovascular fitness \\
Body composition
\end{tabular}


Treatment response

Adverse events

\begin{tabular}{ll}
\hline Notes & Methodological quality score: 3 \\
& Main purpose of exercise: to improve cardiorespiratory fitness
\end{tabular}

\section{Risk of bias}

\begin{tabular}{|c|c|c|}
\hline Bias & Authors' judgement & Support for judgement \\
\hline $\begin{array}{l}\text { Random sequence genera- } \\
\text { tion (selection bias) }\end{array}$ & Low risk & "randomly assigned to AET or UC by using a computer-generated program" \\
\hline $\begin{array}{l}\text { Allocation concealment } \\
\text { (selection bias) }\end{array}$ & Low risk & $\begin{array}{l}\text { "The allocation sequence was generated independently and concealed in } \\
\text { opaque envelopes" }\end{array}$ \\
\hline $\begin{array}{l}\text { Blinding of outcome as- } \\
\text { sessment (detection bias) } \\
\text { All outcomes }\end{array}$ & High risk & "Outcome assessors were not always blinded to group assignment" \\
\hline $\begin{array}{l}\text { Incomplete outcome data } \\
\text { (attrition bias) } \\
\text { All outcomes }\end{array}$ & Low risk & All participants were accounted for \\
\hline $\begin{array}{l}\text { Selective reporting (re- } \\
\text { porting bias) }\end{array}$ & Low risk & Fatigue outcome reported \\
\hline
\end{tabular}

\section{Culos-Reed 2006}

\section{Study characteristics}

\begin{tabular}{ll}
\hline Methods & RCT; 2 groups \\
\hline Participants & 38 cancer survivors, minimum of 3 months post-treatment \\
\hline Interventions & $\begin{array}{l}\text { Exercise: yoga } \\
\text { Control: wait list }\end{array}$ \\
\hline Outcomes & Fatigue \\
& Mood \\
& Symptom stress \\
& Phality of life \\
& Physical fitness \\
& Methodologity \\
Notes & Main purpose of exercise: to improve physical and psychological health \\
\hline
\end{tabular}

\section{Risk of bias}

Bias Authors' judgement Support for judgement


Culos-Reed 2006 (Continued)
Random sequence genera-
Unclear risk
"randomly assigned" but method not reported tion (selection bias)

\begin{tabular}{lll}
\hline $\begin{array}{l}\text { Allocation concealment } \\
\text { (selection bias) }\end{array}$ & Unclear risk & Not stated
\end{tabular}

\begin{tabular}{|c|c|c|}
\hline $\begin{array}{l}\text { Blinding of outcome as- } \\
\text { sessment (detection bias) } \\
\text { All outcomes }\end{array}$ & High risk & Blinding not done \\
\hline $\begin{array}{l}\text { Incomplete outcome data } \\
\text { (attrition bias) } \\
\text { All outcomes }\end{array}$ & Low risk & All participants were accounted for \\
\hline $\begin{array}{l}\text { Selective reporting (re- } \\
\text { porting bias) }\end{array}$ & High risk & Fatigue outcomes not reported and authors focused upon significant results \\
\hline
\end{tabular}

\section{Culos-Reed 2010}

\section{Study characteristics}

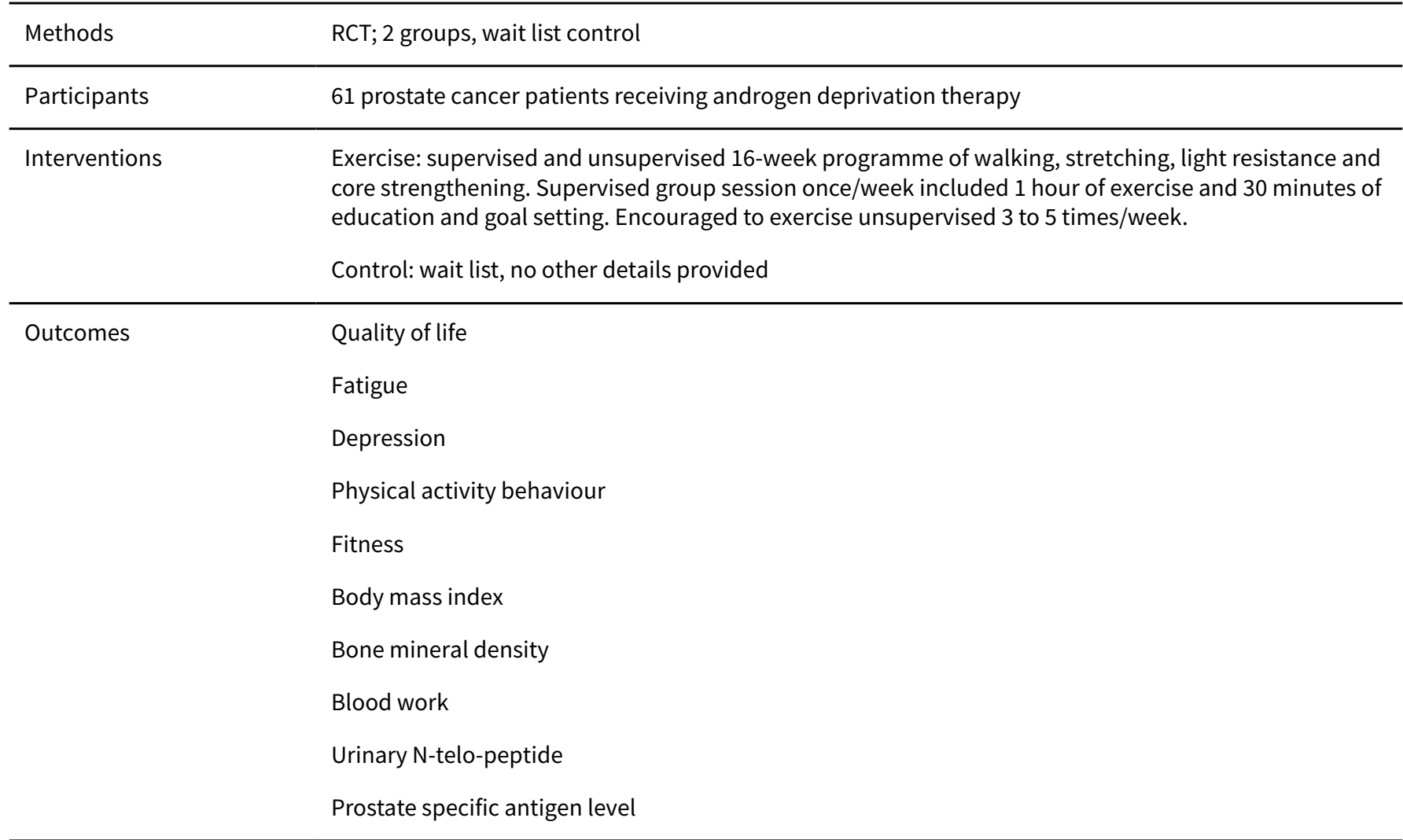

Notes Methodological quality score: 2

Main purpose of exercise: to increase physical activity levels, enhance quality of life, improve fitness and physiological variables

\section{Risk of bias}


Culos-Reed 2010 (Continued)

\begin{tabular}{|c|c|c|}
\hline Bias & Authors' judgement & Support for judgement \\
\hline $\begin{array}{l}\text { Random sequence genera- } \\
\text { tion (selection bias) }\end{array}$ & Unclear risk & "randomized" but method not described \\
\hline $\begin{array}{l}\text { Allocation concealment } \\
\text { (selection bias) }\end{array}$ & Unclear risk & Not stated \\
\hline $\begin{array}{l}\text { Blinding of outcome as- } \\
\text { sessment (detection bias) } \\
\text { All outcomes }\end{array}$ & High risk & Blinding not done \\
\hline $\begin{array}{l}\text { Incomplete outcome data } \\
\text { (attrition bias) } \\
\text { All outcomes }\end{array}$ & Low risk & All participants were accounted for \\
\hline $\begin{array}{l}\text { Selective reporting (re- } \\
\text { porting bias) }\end{array}$ & Low risk & Fatigue outcome reported \\
\hline
\end{tabular}

Daley 2007

\section{Study characteristics}

\begin{tabular}{ll}
\hline Methods & RCT; 3 groups, stratification by chemotherapy and tamoxifen \\
\hline Participants & 108 women 12 to 36 months post-treatment for breast cancer \\
\hline Interventions & Exercise: supervised aerobic exercise 3 times per week for 8 weeks \\
& Placebo exercise: light intensity body conditioning/stretching \\
& Control: usual care \\
\hline Outcomes & Quality of life \\
& Fatigue \\
& Depression \\
& Self perception \\
& Physical activity \\
& Aerobic fitness \\
& Body composition
\end{tabular}

\begin{tabular}{ll}
\hline Notes & Methodological quality score: 3 \\
& Main purpose of exercise: to improve quality of life
\end{tabular}

\section{Risk of bias}

\begin{tabular}{lll}
\hline Bias & Authors' judgement & Support for judgement \\
\hline $\begin{array}{l}\text { Random sequence genera- } \\
\text { tion (selection bias) }\end{array}$ & Low risk & $\begin{array}{l}\text { "A telephone randomization service was provided by an independent trials } \\
\text { unit. Randomization to the three treatment arms was on a 1:1:1 ratio and was } \\
\text { performed using stratified random permutated blocks" }\end{array}$ \\
\hline $\begin{array}{l}\text { Allocation concealment } \\
\text { (selection bias) }\end{array}$ & Low risk & $\begin{array}{l}\text { "A telephone randomization service was provided by an independent trials } \\
\text { unit. Randomization to the three treatment arms was on a 1:1:1 ratio and was } \\
\text { performed using stratified random permutated blocks" }\end{array}$ \\
\hline $\begin{array}{l}\text { Blinding of outcome as- } \\
\text { sessment (detection bias) }\end{array}$ & High risk & Blinding not done \\
\hline
\end{tabular}


Daley 2007 (Continued)

All outcomes

Incomplete outcome data Low risk $\quad$ All participants were accounted for
(attrition bias)

All outcomes

Selective reporting (re- Low risk $\quad$ Fatigue outcome reported
porting bias)

porting bias)

Danhauer 2009

\section{Study characteristics}

\begin{tabular}{ll}
\hline Methods & RCT; 2 groups, wait list control \\
\hline Participants & 27 patients with breat cancer at various different stages of treatment \\
\hline Interventions & $\begin{array}{l}\text { Exercise: yoga, 75-minute supervised group class once/week for } 10 \text { weeks. Average of 6.6 women/ses- } \\
\text { sion. No home practice required. } \\
\text { Control: usual care, wait list }\end{array}$ \\
\hline Outcomes & Physical health status \\
& Quality of life \\
& Fatigue \\
& Spiritual well-being \\
& Depression \\
& Sleep quality \\
Mood
\end{tabular}

$\begin{array}{ll}\text { Notes } & \text { Methodological quality score: } 2 \\ & \text { Main purpose of exercise: to reduce fatigue and psychological distress, and improve sleep and quality } \\ & \text { of life }\end{array}$

of life

\section{Risk of bias}

\begin{tabular}{lll}
\hline Bias & Authors' judgement & Support for judgement \\
\hline $\begin{array}{l}\text { Random sequence genera- } \\
\text { tion (selection bias) }\end{array}$ & Unclear risk & "randomized" but method not described \\
\hline $\begin{array}{l}\text { Allocation concealment } \\
\text { (selection bias) }\end{array}$ & Unclear risk & Not stated \\
\hline $\begin{array}{l}\text { Blinding of outcome as- } \\
\text { sessment (detection bias) } \\
\text { All outcomes }\end{array}$ & High risk & Blinding not done \\
\hline $\begin{array}{l}\text { Incomplete outcome data } \\
\text { (attrition bias) } \\
\text { All outcomes }\end{array}$ & Low risk & All participants were accounted for \\
\hline
\end{tabular}


Danhauer 2009 (Continued)
Selective reporting (re-
Low risk
Fatigue outcome reported porting bias)

Dimeo 1999

\section{Study characteristics}

\begin{tabular}{|c|c|c|}
\hline Methods & \multicolumn{2}{|l|}{$\mathrm{RCT} ; 2$ groups } \\
\hline Participants & \multicolumn{2}{|c|}{$\begin{array}{l}62 \text { cancer patients with various diagnoses due to receive high does chemotherapy followed by autolo- } \\
\text { gous peripheral blood stem cell transplantation }\end{array}$} \\
\hline Interventions & \multicolumn{2}{|c|}{$\begin{array}{l}\text { Exercise: supervised daily biking with a bed ergometer. } 15 \text { x 1-min at 50\% cardiac reserve with 1-min } \\
\text { rest between. } \\
\text { Control: no intervention }\end{array}$} \\
\hline Outcomes & \multicolumn{2}{|c|}{$\begin{array}{l}\text { Mood (including depression, fatigue, anger and vigour) } \\
\text { Symptoms }\end{array}$} \\
\hline Notes & \multicolumn{2}{|c|}{$\begin{array}{l}\text { Methodological quality score: } 1 \\
\text { Main purpose of exercise: to reduce fatigue }\end{array}$} \\
\hline \multicolumn{3}{|l|}{ Risk of bias } \\
\hline Bias & Authors' judgement & Support for judgement \\
\hline $\begin{array}{l}\text { Random sequence genera- } \\
\text { tion (selection bias) }\end{array}$ & High risk & $\begin{array}{l}\text { "patients recruited in odd weeks were included in the training group and pa- } \\
\text { tients recruited in the even weeks were included in the control group" }\end{array}$ \\
\hline $\begin{array}{l}\text { Allocation concealment } \\
\text { (selection bias) }\end{array}$ & Unclear risk & Not stated \\
\hline $\begin{array}{l}\text { Blinding of outcome as- } \\
\text { sessment (detection bias) } \\
\text { All outcomes }\end{array}$ & High risk & Blinding not done \\
\hline $\begin{array}{l}\text { Incomplete outcome data } \\
\text { (attrition bias) } \\
\text { All outcomes }\end{array}$ & Low risk & All participants were accounted for \\
\hline $\begin{array}{l}\text { Selective reporting (re- } \\
\text { porting bias) }\end{array}$ & Low risk & Fatigue outcome reported \\
\hline
\end{tabular}

Dimeo 2004

\section{Study characteristics}

\begin{tabular}{ll}
\hline Methods & RCT; 2 groups, stratified for tumour location \\
\hline Participants & 72 various cancer diagnoses, post anti-cancer treatment \\
\hline Interventions & $\begin{array}{l}\text { Exercise: supervised stationary bike, } 30 \text { mins/per session, } 5 \text { days/week. } 80 \% \text { HRmax or } 13 \text { to } 14 \text { on Borg } \\
\text { scale. }\end{array}$
\end{tabular}


Dimeo 2004 (Continued)

Control: relaxation training 45 mins, 3 times/week

Both groups lasted 3 weeks

\begin{tabular}{|c|c|c|}
\hline Outcomes & \multicolumn{2}{|c|}{$\begin{array}{l}\text { HRQOL (including fatigue) } \\
\text { Physical performance }\end{array}$} \\
\hline Notes & \multicolumn{2}{|c|}{$\begin{array}{l}\text { Methodological quality score: } 3 \\
\text { Main purpose of exercise: to reduce fatigue severity }\end{array}$} \\
\hline \multicolumn{3}{|l|}{ Risk of bias } \\
\hline Bias & Authors' judgement & Support for judgement \\
\hline $\begin{array}{l}\text { Random sequence genera- } \\
\text { tion (selection bias) }\end{array}$ & Low risk & $\begin{array}{l}\text { "Randomisation was carried out using a computer-generated random number } \\
\text { list" }\end{array}$ \\
\hline $\begin{array}{l}\text { Allocation concealment } \\
\text { (selection bias) }\end{array}$ & Low risk & "randomisation sequence was concealed until assignment of interventions" \\
\hline $\begin{array}{l}\text { Blinding of outcome as- } \\
\text { sessment (detection bias) } \\
\text { All outcomes }\end{array}$ & High risk & Blinding not done \\
\hline $\begin{array}{l}\text { Incomplete outcome data } \\
\text { (attrition bias) } \\
\text { All outcomes }\end{array}$ & Unclear risk & $\begin{array}{l}3 \text { participants dropped out of the study; unclear if intention-to-treat analysis } \\
\text { was performed }\end{array}$ \\
\hline $\begin{array}{l}\text { Selective reporting (re- } \\
\text { porting bias) }\end{array}$ & Low risk & Fatigue outcome reported \\
\hline
\end{tabular}

Dodd 2010a

\section{Study characteristics}

\begin{tabular}{ll}
\hline Methods & RCT; 3 groups \\
\hline Participants & $\begin{array}{l}106 \text { patients, majority with breast cancer but patients with ovarian and colorectal cancer also included. } \\
\text { All patients were due to commence chemotherapy }\end{array}$ \\
\hline Interventions & $\begin{array}{l}\text { Exercise during chemotherapy: home-based for } 1 \text { year, } 3 \text { to } 5 \text { times/week, } 20 \text { to } 30 \text {-minute/session } \\
\text { at } 60 \% \text { to } 80 \% \mathrm{VO}_{2} \text { peak or } 12 \text { to } 14 \text { on Borg scale (somewhat hard). Weekly follow-up calls to assess } \\
\text { progress and adjust intensity. }\end{array}$ \\
& $\begin{array}{l}\text { Exercise post-chemotherapy: home-based for } 6 \text { to } 8 \text { months, } 3 \text { to } 5 \text { times/week, } 20 \text { to } 30 \text {-minute/ses- } \\
\text { sion at } 60 \text { to } 80 \% \text { VO }{ }_{2} \text { peak or } 12 \text { to } 14 \text { on Borg scale (somewhat hard). Weekly follow-up calls to assess } \\
\text { progress and adjust intensity. }\end{array}$ \\
& $\begin{array}{l}\text { Control: usual care, no exercise prescription. Telephoned weekly to enquire about health and general } \\
\text { response to cancer treatment. }\end{array}$ \\
& $\begin{array}{l}\text { Fatigue } \\
\text { Outcomes }\end{array}$ \\
& Deepression disturbance \\
& Pain
\end{tabular}


Dodd 2010a (Continued)

Physical ability

Quality of life (not included in the analysis)

$\begin{array}{ll}\text { Notes } & \text { Methodological quality score: } 2 \\ & \text { Main purpose of exercise: to reduce fatigue }\end{array}$

\section{Risk of bias}

Bias

Authors' judgement Support for judgement

Random sequence genera- Unclear risk "randomized" but method not stated

tion (selection bias)

\begin{tabular}{lll}
\hline $\begin{array}{l}\text { Allocation concealment } \\
\text { (selection bias) }\end{array}$ & Unclear risk & Not stated
\end{tabular}

Blinding of outcome as- High risk Blinding not done

sessment (detection bias)

All outcomes

\begin{tabular}{lll}
\hline $\begin{array}{l}\text { Incomplete outcome data } \\
\text { (attrition bias) } \\
\text { All outcomes }\end{array}$ & Low risk & All participants were accounted for \\
\hline $\begin{array}{l}\text { Selective reporting (re- } \\
\text { porting bias) }\end{array}$ & Low risk & Fatigue outcome reported \\
\hline
\end{tabular}

\section{Dodd 2010b}

\section{Study characteristics}

\begin{tabular}{|c|c|c|}
\hline Methods & See Dodd 2010a & \\
\hline Participants & See Dodd 2010a & \\
\hline Interventions & See Dodd 2010a & \\
\hline Outcomes & See Dodd 2010a & \\
\hline Notes & See Dodd 2010a & \\
\hline \multicolumn{3}{|l|}{ Risk of bias } \\
\hline Bias & Authors' judgement & Support for judgement \\
\hline $\begin{array}{l}\text { Random sequence genera- } \\
\text { tion (selection bias) }\end{array}$ & Unclear risk & "randomized" but method not stated \\
\hline $\begin{array}{l}\text { Allocation concealment } \\
\text { (selection bias) }\end{array}$ & Unclear risk & Not stated \\
\hline $\begin{array}{l}\text { Blinding of outcome as- } \\
\text { sessment (detection bias) } \\
\text { All outcomes }\end{array}$ & High risk & Blinding not done \\
\hline
\end{tabular}


Dodd 2010b (Continued)
Incomplete outcome data
Low risk
All participants were accounted for
(attrition bias)

All outcomes

Selective reporting (re- Low risk $\quad$ Fatigue outcome reported
porting bias)

Drouin 2005

\section{Study characteristics}

\begin{tabular}{|c|c|c|}
\hline Methods & \multicolumn{2}{|l|}{$\mathrm{RCT} ; 2$ groups } \\
\hline Participants & \multicolumn{2}{|c|}{23 stage 0 -III breast cancer patients prior to radiotherapy, sedentary } \\
\hline Interventions & \multicolumn{2}{|c|}{$\begin{array}{l}\text { Exercise: home-based individualised walking programme. } 20 \text { to } 45 \text { mins of walking } 3 \text { to } 5 \text { times/week at } \\
50 \% \text { to } 70 \% \text { max HR. } \\
\text { Control: stretching } 3 \text { to } 5 \text { times/week }\end{array}$} \\
\hline Outcomes & \multicolumn{2}{|l|}{$\begin{array}{l}\text { Aerobic capacity } \\
\text { Fatigue } \\
\text { Mood }\end{array}$} \\
\hline Notes & \multicolumn{2}{|c|}{$\begin{array}{l}\text { Methodological quality score: } 3 \\
\text { Main purpose of exercise: to improve cardiorespiratory fitness, fatigue and psychological factors }\end{array}$} \\
\hline \multicolumn{3}{|l|}{ Risk of bias } \\
\hline Bias & Authors' judgement & Support for judgement \\
\hline $\begin{array}{l}\text { Random sequence genera- } \\
\text { tion (selection bias) }\end{array}$ & Low risk & "randomly assigned...using a random number table" \\
\hline $\begin{array}{l}\text { Allocation concealment } \\
\text { (selection bias) }\end{array}$ & Unclear risk & Not stated \\
\hline $\begin{array}{l}\text { Blinding of outcome as- } \\
\text { sessment (detection bias) } \\
\text { All outcomes }\end{array}$ & High risk & Blinding not done \\
\hline $\begin{array}{l}\text { Incomplete outcome data } \\
\text { (attrition bias) } \\
\text { All outcomes }\end{array}$ & Low risk & All participants were accounted for \\
\hline $\begin{array}{l}\text { Selective reporting (re- } \\
\text { porting bias) }\end{array}$ & Low risk & Fatigue outcome reported \\
\hline
\end{tabular}

Galantino 2003

\section{Study characteristics}

Methods RCT; 2 groups


Galantino 2003 (Continued)

Participants

11 stage II-IV breast cancer patients reporting cancer-related fatigue and having received adjuvant therapy within past year

Interventions

Exercise: Tai Chi, initial instruction and supporting video, then home-based 3 times/week for 6 weeks.

Weekly phone calls.

Control: walking booklet, advised to walk 3 times/week for 6 weeks. Weekly phone calls.

\begin{tabular}{ll}
\hline Outcomes & Fatigue \\
& Body composition \\
& 6 -minute walk test \\
& Physical well-being \\
& Emotional well-being \\
& Social/family well-being \\
\hline Notes & Methodological quality score: 2 \\
& Main purpose of exercise: to improve fatigue and body mass index
\end{tabular}

\section{Risk of bias}

\begin{tabular}{|c|c|c|}
\hline Bias & Authors' judgement & Support for judgement \\
\hline $\begin{array}{l}\text { Random sequence genera- } \\
\text { tion (selection bias) }\end{array}$ & Low risk & "randomized...by the use of a table of random numbers" \\
\hline $\begin{array}{l}\text { Allocation concealment } \\
\text { (selection bias) }\end{array}$ & Unclear risk & Not stated \\
\hline $\begin{array}{l}\text { Blinding of outcome as- } \\
\text { sessment (detection bias) } \\
\text { All outcomes }\end{array}$ & High risk & Blinding not done \\
\hline $\begin{array}{l}\text { Incomplete outcome data } \\
\text { (attrition bias) } \\
\text { All outcomes }\end{array}$ & High risk & Number of participants varies with no explanation \\
\hline $\begin{array}{l}\text { Selective reporting (re- } \\
\text { porting bias) }\end{array}$ & Low risk & Fatigue outcome reported \\
\hline
\end{tabular}

Galvão 2010

\section{Study characteristics}

\begin{tabular}{ll}
\hline Methods & RCT; 2 groups parallel design \\
\hline Participants & 57 patients with prostate cancer, some were receiving radiotherapy \\
\hline Interventions & $\begin{array}{l}\text { Exercise: combined progressive resistance and aerobic training twice/week for } 12 \text { weeks, supervised in } \\
\text { small groups }(n=1 \text { to } 5) \text {. Resistance progressed from } 12 \text { to } 6 \text { repetition maximum with } 2 \text { to } 4 \text { sets/exer- } \\
\text { cise. Aerobic training: } 15 \text { to } 20 \text { minutes of cycling, walking or jogging at } 65 \% \text { to } 80 \% \text { Hmax, perceived } \\
\text { exertion } 11 \text { to } 13 \text { on Borg scale. } \\
\text { Control: usual care }\end{array}$ \\
\hline Outcomes & Fatigue \\
Quality of life
\end{tabular}


Galvão 2010 (Continued)

\author{
Aerobic capacity \\ Balance and falls self efficacy \\ Functional performance \\ Muscle strength \\ Muscle endurance \\ Body composition \\ Blood profile
}

\begin{tabular}{ll}
\hline Notes & Methodological quality score: 3 \\
& Main purpose of exercise: to increase muscle mass and strength, physical function, cardiorespiratory \\
capacity and health status.
\end{tabular}

\title{
Risk of bias
}

\begin{tabular}{|c|c|c|}
\hline Bias & Authors' judgement & Support for judgement \\
\hline $\begin{array}{l}\text { Random sequence genera- } \\
\text { tion (selection bias) }\end{array}$ & Low risk & $\begin{array}{l}\text { "participants were randomly assigned...1:1 using a computer random assign- } \\
\text { ment program" }\end{array}$ \\
\hline $\begin{array}{l}\text { Allocation concealment } \\
\text { (selection bias) }\end{array}$ & Low risk & $\begin{array}{l}\text { "The allocation sequence was concealed from the project coordinator and ex- } \\
\text { ercise physiologist" }\end{array}$ \\
\hline $\begin{array}{l}\text { Blinding of outcome as- } \\
\text { sessment (detection bias) } \\
\text { All outcomes }\end{array}$ & High risk & Blinding not done \\
\hline $\begin{array}{l}\text { Incomplete outcome data } \\
\text { (attrition bias) } \\
\text { All outcomes }\end{array}$ & Unclear risk & Some missing data \\
\hline $\begin{array}{l}\text { Selective reporting (re- } \\
\text { porting bias) }\end{array}$ & Low risk & Fatigue outcome reported \\
\hline
\end{tabular}

Headley 2004

\section{Study characteristics}

\begin{tabular}{ll}
\hline Methods & RCT; 2 groups \\
\hline Participants & 38 stage IV breast cancer patients due to initiate chemotherapy \\
\hline Interventions & $\begin{array}{l}\text { Exercise: } 30 \text {-min seated exercises, } 3 \text { times/week with at least } 1 \text { day between each session. Consisted of } \\
\text { 5-min warm-up, 20-min moderate intensity repetitive motion exercises, 5-min cool down. } \\
\text { Control: no intervention }\end{array}$ \\
\hline Outcomes & $\begin{array}{l}\text { Quality of life } \\
\text { Fatigue }\end{array}$ \\
\hline Notes & Methodological quality score: 2 \\
& Main purpose of exercise: to improve quality of life and reduce fatigue
\end{tabular}


Headley 2004 (Continued)

Risk of bias

\begin{tabular}{|c|c|c|}
\hline Bias & Authors' judgement & Support for judgement \\
\hline $\begin{array}{l}\text { Random sequence genera- } \\
\text { tion (selection bias) }\end{array}$ & Low risk & $\begin{array}{l}\text { "Participants were assigned randomly to either the control or intervention } \\
\text { group by computer" }\end{array}$ \\
\hline $\begin{array}{l}\text { Allocation concealment } \\
\text { (selection bias) }\end{array}$ & Unclear risk & Not stated \\
\hline $\begin{array}{l}\text { Blinding of outcome as- } \\
\text { sessment (detection bias) } \\
\text { All outcomes }\end{array}$ & High risk & Blinding not done \\
\hline $\begin{array}{l}\text { Incomplete outcome data } \\
\text { (attrition bias) } \\
\text { All outcomes }\end{array}$ & Low risk & All participants were accounted for \\
\hline $\begin{array}{l}\text { Selective reporting (re- } \\
\text { porting bias) }\end{array}$ & Low risk & Fatigue outcome reported \\
\hline
\end{tabular}

Heim 2007

\section{Study characteristics}

\begin{tabular}{ll}
\hline Methods & RCT; 2 groups \\
\hline Participants & 63 breast cancer patients at least 6 weeks post-surgery and chemotherapy \\
\hline Interventions & $\begin{array}{l}\text { Exercise: combined resistance exercises, stretching and aerobic walking in combination with a com- } \\
\text { plex rehabilitation programme. Unsupervised, strengthening and stretching } 3 \text { times/week, aerobic } \\
\text { walking } 30 \text { minutes, twice/week. }\end{array}$ \\
& Control: complex rehabilitation programme only \\
\hline Outcomes & Fatigue \\
& Quality of life \\
& Aerobic capacity \\
& Anxiety \\
& Depression \\
& Physical activity \\
& Physical activity motivation \\
Muscle strength
\end{tabular}

Notes Methodological quality score: 0

Main purpose of exercise: to reduce fatigue

\section{Risk of bias}


Heim 2007 (Continued)

$\begin{array}{ll}\begin{array}{l}\text { Random sequence genera- High risk } \\ \text { tion (selection bias) }\end{array} & \begin{array}{l}\text { "randomized according to their admission to hospital: depending on the alter- } \\ \text { nating weeks" }\end{array}\end{array}$

tion (selection bias)

Allocation concealment High risk $\quad$ Not done
(selection bias)

$\begin{array}{lll}\text { Blinding of outcome as- } & \text { High risk } & \text { Blinding not done } \\ \text { sessment (detection bias) } & \end{array}$

All outcomes

\begin{tabular}{lll}
\hline $\begin{array}{l}\text { Incomplete outcome data } \\
\text { (attrition bias) }\end{array}$ & Unclear risk & No description of drop-outs \\
All outcomes & \\
\hline $\begin{array}{l}\text { Selective reporting (re- } \\
\text { porting bias) }\end{array}$ & Low risk & Fatigue outcome reported \\
\hline
\end{tabular}

Hwang 2008

\section{Study characteristics}

\begin{tabular}{ll}
\hline Methods & RCT; 2 groups \\
\hline Participants & 37 patients with breast cancer, post-surgery and due to receive radiotherapy \\
\hline Interventions & $\begin{array}{l}\text { Exercise: supervised aerobic (treadmill walking and bicycling), some stretching (shoulder) and } \\
\text { strengthening exercises, } 50 \text { minutes, } 3 \text { times/week for } 5 \text { weeks during radiation therapy. Target heart } \\
\text { rate } 50 \% \text { to } 70 \% \text { HRmax. }\end{array}$ \\
Control: shoulder range of movement exercises, encouraged to continue normal activities
\end{tabular}

\begin{tabular}{|c|c|c|}
\hline \multirow[t]{4}{*}{ Outcomes } & \multicolumn{2}{|l|}{ Fatigue } \\
\hline & \multicolumn{2}{|l|}{ Quality of life } \\
\hline & \multicolumn{2}{|c|}{ Shoulder range of movement } \\
\hline & \multicolumn{2}{|l|}{ Pain } \\
\hline Notes & \multicolumn{2}{|c|}{$\begin{array}{l}\text { Methodological quality score: } 2 \\
\text { Main purpose of exercise: to improve quality of life and shoulder mobility and reduce fatigue and pair }\end{array}$} \\
\hline \multicolumn{3}{|l|}{ Risk of bias } \\
\hline Bias & Authors' judgement & Support for judgement \\
\hline $\begin{array}{l}\text { Random sequence genera- } \\
\text { tion (selection bias) }\end{array}$ & Unclear risk & "randomly assigned" but method not reported \\
\hline $\begin{array}{l}\text { Allocation concealment } \\
\text { (selection bias) }\end{array}$ & Unclear risk & Not stated \\
\hline $\begin{array}{l}\text { Blinding of outcome as- } \\
\text { sessment (detection bias) } \\
\text { All outcomes }\end{array}$ & High risk & Blinding not done \\
\hline
\end{tabular}


Hwang 2008 (Continued)
Incomplete outcome data
Low risk
All participants were accounted for
(attrition bias)

All outcomes

Selective reporting (re- Low risk $\quad$ Fatigue outcome reported
porting bias)

\section{Lee 2010}

\section{Study characteristics}

\begin{tabular}{ll}
\hline Methods & RCT; 3 groups; intervention groups stratified by operation type, historical control \\
\hline Participants & 39 patients with breast cancer post-treatment (includes 18 drawn from a historical control cohort) \\
\hline Interventions & $\begin{array}{l}\text { Scapula exercise: supervised shoulder stretching and strengthening for } 40 \text { minutes once/week for } 8 \\
\text { weeks } \\
\text { General exercise: supervised range of motion and body conditioning for } 40 \text { minutes once/week for } 8 \\
\text { weeks } \\
\text { Control: historical group }\end{array}$ \\
\hline
\end{tabular}

\begin{tabular}{ll}
\hline Outcomes & Fatigue \\
& Quality of life \\
Depression \\
Shoulder disability, function and range of movement \\
Pain
\end{tabular}

$\begin{array}{ll}\text { Notes } & \text { Methodological quality score: } 1 \\ & \text { Main purpose of exercise: to reduce upper limb dysfunction }\end{array}$

\section{Risk of bias}

\begin{tabular}{lll}
\hline Bias & Authors' judgement & Support for judgement \\
\hline $\begin{array}{l}\text { Random sequence genera- } \\
\text { tion (selection bias) }\end{array}$ & Low risk & "Randomization to the two treatment arms was achieved on a 1:1 ratio" \\
\hline $\begin{array}{l}\text { Allocation concealment } \\
\text { (selection bias) }\end{array}$ & Unclear risk & Not stated \\
\hline $\begin{array}{l}\text { Blinding of outcome as- } \\
\text { sessment (detection bias) } \\
\text { All outcomes }\end{array}$ & High risk & Blinding not done \\
\hline $\begin{array}{l}\text { Incomplete outcome data } \\
\text { (attrition bias) } \\
\text { All outcomes }\end{array}$ & Low risk & All participants were accounted for \\
\hline $\begin{array}{l}\text { Selective reporting (re- } \\
\text { porting bias) }\end{array}$ & Low risk & \\
\hline
\end{tabular}


McKenzie 2003

\section{Study characteristics}

\begin{tabular}{|c|c|c|}
\hline Methods & \multicolumn{2}{|l|}{ RCT; 2 groups } \\
\hline Participants & \multicolumn{2}{|c|}{14 stage I-II breast cancer patient at least 6 months post-treatment with unilateral lymphoedema } \\
\hline Interventions & \multicolumn{2}{|c|}{$\begin{array}{l}\text { Exercise: } 3 \text { times per week supervised resistance training, strengthening, aerobic arm ergometry. } \\
\text { Warm-up, } 5 \text { minutes stretching, strength exercises then cool down. Strength exercise } 2 \times 10 \text { reps week } \\
\text { one the } 3 \times 10 \text { reps. Week } 3 \text { arm ergometry added. }\end{array}$} \\
\hline Outcomes & \multicolumn{2}{|l|}{$\begin{array}{l}\text { Fatigue } \\
\text { Arm volume } \\
\text { Quality of life }\end{array}$} \\
\hline Notes & \multicolumn{2}{|c|}{$\begin{array}{l}\text { Methodological quality score: } 1 \\
\text { Main purpose of exercise: to reduce lymphoedema }\end{array}$} \\
\hline \multicolumn{3}{|l|}{ Risk of bias } \\
\hline Bias & Authors' judgement & Support for judgement \\
\hline $\begin{array}{l}\text { Random sequence genera- } \\
\text { tion (selection bias) }\end{array}$ & Unclear risk & "randomly assigned" but method not described \\
\hline $\begin{array}{l}\text { Allocation concealment } \\
\text { (selection bias) }\end{array}$ & Unclear risk & Not stated \\
\hline $\begin{array}{l}\text { Blinding of outcome as- } \\
\text { sessment (detection bias) } \\
\text { All outcomes }\end{array}$ & High risk & Blinding not done \\
\hline $\begin{array}{l}\text { Incomplete outcome data } \\
\text { (attrition bias) } \\
\text { All outcomes }\end{array}$ & Low risk & All participants were accounted for \\
\hline $\begin{array}{l}\text { Selective reporting (re- } \\
\text { porting bias) }\end{array}$ & Low risk & Fatigue outcome reported \\
\hline
\end{tabular}

McNeely 2008

\section{Study characteristics}

\begin{tabular}{ll}
\hline Methods & RCT; 2 groups parallel design \\
\hline Participants & 52 patients following treatment for head and neck cancer \\
\hline Interventions & $\begin{array}{l}\text { Exercise: progressive resistance exercise training; } 2 \text { supervised sessions/week with an optional } 3 \text { rd ses- } \\
\text { sion either at home or in the centre for } 12 \text { weeks. Initially } 2 \text { sets of } 10 \text { to } 15 \text { reps of } 5 \text { to } 8 \text { exercises at } \\
25 \% \text { to } 30 \% 1 \text { RM and slowly progressing to } 60 \% \text { to } 70 \% 1 \text { RM by week } 12 . \\
\text { Control: standardised therapeutic protocol with light weights and stretching }\end{array}$ \\
\hline
\end{tabular}

Outcomes

Fatigue 
McNeely 2008 (Continued)

Quality of life

Shoulder pain, disability and range of movement

Upper limb strength and muscle endurance

$\begin{array}{ll}\text { Notes } & \text { Methodological quality score: } 3 \\ \text { Main purpose of exercise: to reduce upper extremity pain and dysfunction }\end{array}$

\section{Risk of bias}

\begin{tabular}{|c|c|c|}
\hline Bias & Authors' judgement & Support for judgement \\
\hline $\begin{array}{l}\text { Random sequence genera- } \\
\text { tion (selection bias) }\end{array}$ & Low risk & "Participants were assigned randomly...using a computer generated code" \\
\hline $\begin{array}{l}\text { Allocation concealment } \\
\text { (selection bias) }\end{array}$ & Low risk & $\begin{array}{l}\text { "allocation sequence...sequentially numbered and sealed (opaque) en- } \\
\text { velopes." }\end{array}$ \\
\hline $\begin{array}{l}\text { Blinding of outcome as- } \\
\text { sessment (detection bias) } \\
\text { All outcomes }\end{array}$ & Unclear risk & $\begin{array}{l}\text { "Independent assessors who were blinded to group" but fatigue was self re- } \\
\text { port }\end{array}$ \\
\hline $\begin{array}{l}\text { Incomplete outcome data } \\
\text { (attrition bias) } \\
\text { All outcomes }\end{array}$ & Low risk & All participants were accounted for \\
\hline $\begin{array}{l}\text { Selective reporting (re- } \\
\text { porting bias) }\end{array}$ & Low risk & Fatigue outcome reported \\
\hline
\end{tabular}

Milne 2008

\section{Study characteristics}

\begin{tabular}{ll}
\hline Methods & RCT; 2 group cross-over design \\
\hline Participants & 58 breast cancer patients within 2 years of completing adjuvant therapy \\
\hline Interventions & $\begin{array}{l}\text { Exercise: } 2 \text { times per week supervised group programme including aerobic and resistance training for } \\
12 \text { weeks } \\
\text { Control: usual care and phone call every } 3 \text { weeks }\end{array}$ \\
\hline Outcomes & Quality of life \\
& Fatigue \\
& Anxiety \\
\hline Notes & Methodological quality score: 3. \\
& Main purpose of exercise: to improve quality of life \\
\hline
\end{tabular}

\section{Risk of bias}

Bias Authors' judgement Support for judgement


Milne 2008 (Continued)

\begin{tabular}{|c|c|c|}
\hline $\begin{array}{l}\text { Random sequence genera- } \\
\text { tion (selection bias) }\end{array}$ & Low risk & "Participants were randomly assigned...using a computer-generated program" \\
\hline $\begin{array}{l}\text { Allocation concealment } \\
\text { (selection bias) }\end{array}$ & Low risk & $\begin{array}{l}\text { "Group assignments were concealed from the project director who recruited } \\
\text { participants to the trial" }\end{array}$ \\
\hline $\begin{array}{l}\text { Blinding of outcome as- } \\
\text { sessment (detection bias) } \\
\text { All outcomes }\end{array}$ & High risk & Blinding not done \\
\hline $\begin{array}{l}\text { Incomplete outcome data } \\
\text { (attrition bias) } \\
\text { All outcomes }\end{array}$ & Low risk & All participants were accounted for \\
\hline $\begin{array}{l}\text { Selective reporting (re- } \\
\text { porting bias) }\end{array}$ & Low risk & Fatigue outcome reported \\
\hline
\end{tabular}

Moadel 2007

\section{Study characteristics}

\begin{tabular}{|c|c|}
\hline Methods & RCT; 2 groups, wait-list control, stratification by cancer treatment \\
\hline Participants & $\begin{array}{l}128 \text { breast cancer patients diagnosed between } 2 \text { weeks and } 5 \text { years previously; } 48 \% \text { received adjuvant } \\
\text { therapy during the study }\end{array}$ \\
\hline \multirow[t]{2}{*}{ Interventions } & $\begin{array}{l}\text { Exercise: yoga, } 12 \text { weeks of one } 1.5 \text { hour group class/week, asked to practice at home daily. Were also } \\
\text { permitted to attend additional classes. }\end{array}$ \\
\hline & Control: wait list \\
\hline \multirow[t]{4}{*}{ Outcomes } & Fatigue \\
\hline & Quality of life \\
\hline & Distress including anxiety \\
\hline & Spiritual well-being \\
\hline
\end{tabular}

\begin{tabular}{ll}
\hline Notes & Methodological quality score: 2 \\
Main purpose of exercise: to improve quality of life \\
\hline
\end{tabular}

\section{Risk of bias}

\begin{tabular}{lll}
\hline Bias & Authors' judgement & Support for judgement \\
\hline $\begin{array}{l}\text { Random sequence genera- } \\
\text { tion (selection bias) }\end{array}$ & Unclear risk & "Randomly assigned" but method not stated \\
\hline $\begin{array}{l}\text { Allocation concealment } \\
\text { (selection bias) }\end{array}$ & Unclear risk & Not stated \\
\hline $\begin{array}{l}\text { Blinding of outcome as- } \\
\text { sessment (detection bias) } \\
\text { All outcomes }\end{array}$ & High risk & Blinding not done \\
\hline
\end{tabular}


Moadel 2007 (Continued)
Incomplete outcome data
Low risk
All participants were accounted for
(attrition bias)

All outcomes

Selective reporting (re- Low risk $\quad$ Fatigue outcome reported
porting bias)

\section{Mock 1994}

\section{Study characteristics}

\begin{tabular}{|c|c|}
\hline Methods & RCT; 2 groups \\
\hline Participants & 18 stage I or II breast cancer post-surgery, prior to adjuvant chemotherapy \\
\hline Interventions & $\begin{array}{l}\text { Exercise: home-based walking and support group. Walking: brisk incremental walk } 10 \text { to } 45 \text { mins with } \\
5 \text { min cool down, } 4 \text { to } 5 \text { times/week. Support group: } 90 \text { mins every } 2 \text { weeks. Continued throughout } \\
\text { chemotherapy treatment. } \\
\text { Control: no intervention }\end{array}$ \\
\hline Outcomes & $\begin{array}{l}\text { Physical function } \\
\text { Psychosocial adjustment } \\
\text { Self concept } \\
\text { Body image } \\
\text { Symptom intensity (nausea, vomiting, fatigue, hair loss, difficulty sleeping, anxiety, depression, mouth } \\
\text { sores, irritability, diarrhoea and pain) }\end{array}$ \\
\hline Notes & $\begin{array}{l}\text { Methodological quality score: } 1 \\
\text { Main purpose of exercise: to improve physical and psychological adaptation }\end{array}$ \\
\hline
\end{tabular}

\section{Risk of bias}

\begin{tabular}{|c|c|c|}
\hline Bias & Authors' judgement & Support for judgement \\
\hline $\begin{array}{l}\text { Random sequence genera- } \\
\text { tion (selection bias) }\end{array}$ & Unclear risk & "randomly assigned" but method not described \\
\hline $\begin{array}{l}\text { Allocation concealment } \\
\text { (selection bias) }\end{array}$ & Unclear risk & Not stated \\
\hline $\begin{array}{l}\text { Blinding of outcome as- } \\
\text { sessment (detection bias) } \\
\text { All outcomes }\end{array}$ & High risk & Blinding not done \\
\hline $\begin{array}{l}\text { Incomplete outcome data } \\
\text { (attrition bias) } \\
\text { All outcomes }\end{array}$ & High risk & Not all participants were accounted for \\
\hline $\begin{array}{l}\text { Selective reporting (re- } \\
\text { porting bias) }\end{array}$ & Low risk & Fatigue outcome reported \\
\hline
\end{tabular}


Mock 1997

\section{Study characteristics}

\begin{tabular}{|c|c|c|}
\hline Methods & \multicolumn{2}{|l|}{ CCT, 2 groups } \\
\hline Participants & \multicolumn{2}{|c|}{46 stage I and II breast cancer patients, post-surgery, receiving radiotherapy } \\
\hline Interventions & \multicolumn{2}{|c|}{$\begin{array}{l}\text { Exercise: individualised brisk } 20 \text { to } 30 \text {-min incremental walk followed by } 5 \text {-min cool down } 4 \text { to } 5 \text { times/ } \\
\text { week in own setting } \\
\text { Control: no intervention }\end{array}$} \\
\hline Outcomes & \multicolumn{2}{|c|}{$\begin{array}{l}\text { Physical function (12-min walk test) } \\
\text { Symptoms } \\
\text { Fatigue }\end{array}$} \\
\hline Notes & $\begin{array}{l}\text { Methodological qualit } \\
\text { Main purpose of exerc }\end{array}$ & $\begin{array}{l}\text { score: } 2 \\
\text { e: to increase physical function and reduce symptom intensity }\end{array}$ \\
\hline \multicolumn{3}{|l|}{ Risk of bias } \\
\hline Bias & Authors' judgement & Support for judgement \\
\hline $\begin{array}{l}\text { Random sequence genera- } \\
\text { tion (selection bias) }\end{array}$ & High risk & $\begin{array}{l}\text { "Following random assignment of the first subject, subsequent subjects were } \\
\text { alternately assigned" }\end{array}$ \\
\hline $\begin{array}{l}\text { Allocation concealment } \\
\text { (selection bias) }\end{array}$ & Unclear risk & Not stated \\
\hline $\begin{array}{l}\text { Blinding of outcome as- } \\
\text { sessment (detection bias) } \\
\text { All outcomes }\end{array}$ & High risk & Blinding not done \\
\hline $\begin{array}{l}\text { Incomplete outcome data } \\
\text { (attrition bias) } \\
\text { All outcomes }\end{array}$ & Unclear risk & $\begin{array}{l}4 \text { participants withdrew or dropped out of the study and were not included in } \\
\text { the analysis }\end{array}$ \\
\hline $\begin{array}{l}\text { Selective reporting (re- } \\
\text { porting bias) }\end{array}$ & Low risk & Fatigue outcome reported \\
\hline
\end{tabular}

Mock 2005

\section{Study characteristics}

\begin{tabular}{ll}
\hline Methods & RCT; 2 groups, stratification by type of adjuvant cancer therapy \\
\hline Participants & $\begin{array}{l}119 \text { breast cancer patients post-surgery prior to any other adjuvant therapy. Exercising less than } 45 \\
\text { mins per week }\end{array}$ \\
\hline Interventions & $\begin{array}{l}\text { Exercise: home-based walking programme during treatment. } 5 \text { to } 6 \text { times/week at } ~ 50 \% \text { to } 70 \% \\
\text { HRmax. } 15 \text { mins per session initially increasing to } 30 \text { mins. Booklet and video provided. Contacted fort- } \\
\text { nightly. } \\
\text { Control: no intervention }\end{array}$ \\
\hline Outcomes & $\begin{array}{l}\text { Fatigue } \\
\text { Physical function } \\
12-\text { min walk }\end{array}$ \\
\hline
\end{tabular}


Mock 2005 (Continued)

$$
\text { Activity levels }
$$

Notes Methodological quality score: 3

Main purpose of exercise: to reduce fatigue

\section{Risk of bias}

\begin{tabular}{|c|c|c|}
\hline Bias & Authors' judgement & Support for judgement \\
\hline $\begin{array}{l}\text { Random sequence genera- } \\
\text { tion (selection bias) }\end{array}$ & Low risk & "computer-generated randomization assignments" \\
\hline $\begin{array}{l}\text { Allocation concealment } \\
\text { (selection bias) }\end{array}$ & Low risk & $\begin{array}{l}\text { "Consecutively numbered sealed opaque envelopes...were prepared at the co- } \\
\text { ordinating centre and opened at the site following baseline testing for each } \\
\text { participant." }\end{array}$ \\
\hline $\begin{array}{l}\text { Blinding of outcome as- } \\
\text { sessment (detection bias) } \\
\text { All outcomes }\end{array}$ & High risk & Blinding not done \\
\hline $\begin{array}{l}\text { Incomplete outcome data } \\
\text { (attrition bias) } \\
\text { All outcomes }\end{array}$ & Low risk & All participants were accounted for \\
\hline $\begin{array}{l}\text { Selective reporting (re- } \\
\text { porting bias) }\end{array}$ & Low risk & Fatigue outcome reported \\
\hline
\end{tabular}

Monga 2007

\section{Study characteristics}

\begin{tabular}{ll}
\hline Methods & RCT; 2 groups, stratified by activity level \\
\hline Participants & 21 patients with prostate cancer due to receive radiotherapy \\
\hline Interventions & $\begin{array}{l}\text { Exercise: supervised aerobic exercise (walking on a treadmill), } 3 \text { times/week for } 8 \text { weeks. 10-min warm- } \\
\text { up, } 30 \text { aerobic, } 5 \text { to } 10 \text {-min cool down. Target HR }=(0.65)(H R m a x)+\text { resting HR }\end{array}$ \\
& Control: usual care \\
\hline Outcomes & Fatigue \\
& Aerobic fitness \\
& Quality of life \\
& Depression \\
& Flexibility \\
& Strength \\
\hline
\end{tabular}

\begin{tabular}{ll}
\hline Notes & Methodological quality score: 2 \\
& Main purpose of exercise: to prevent fatigue and improve quality of life
\end{tabular}

\section{Risk of bias}


Monga 2007 (Continued)

\begin{tabular}{|c|c|c|}
\hline Bias & Authors' judgement & Support for judgement \\
\hline $\begin{array}{l}\text { Random sequence genera- } \\
\text { tion (selection bias) }\end{array}$ & Unclear risk & "randomly assigned" but method not described \\
\hline $\begin{array}{l}\text { Allocation concealment } \\
\text { (selection bias) }\end{array}$ & Unclear risk & Not stated \\
\hline $\begin{array}{l}\text { Blinding of outcome as- } \\
\text { sessment (detection bias) } \\
\text { All outcomes }\end{array}$ & High risk & Blinding not done \\
\hline $\begin{array}{l}\text { Incomplete outcome data } \\
\text { (attrition bias) } \\
\text { All outcomes }\end{array}$ & Low risk & All participants were accounted for \\
\hline $\begin{array}{l}\text { Selective reporting (re- } \\
\text { porting bias) }\end{array}$ & Low risk & Fatigue outcome reported \\
\hline
\end{tabular}

Mustian 2009

\section{Study characteristics}

\begin{tabular}{ll}
\hline Methods & RCT; 2 group, stratified by diagnosis \\
\hline Participants & 38 patients with breast or prostate cancer receiving radiotherapy \\
\hline Interventions & Exercise: home-based aerobic and resistance training every day for 4 weeks. Target was to increase \\
steps by $5 \%$ to $20 \%$ each day up to 10,000 steps at a moderate intensity ( $60 \%$ to $70 \%$ HR reserve). Plus \\
11 resistance exercises, increasing repetitions up to 4 sets of 15 with moderate resistance. \\
Control: usual care, requested not to commence formal exercise programme
\end{tabular}

\begin{tabular}{ll}
\hline Outcomes & Fatigue \\
& Quality of life \\
& Aerobic capacity \\
& Strength \\
& Body composition \\
& Adherence \\
\hline Notes & Methodological quality score: 2 \\
& $\begin{array}{l}\text { Main purpose of exercise: to increase aerobic capacity, strength, muscle mass, fatigue and quality of } \\
\text { life }\end{array}$ \\
\hline Risk of bias & Authors' judgement Support for judgement \\
\hline Bias & Unclear risk "randomized, using a randomization scheme with blocks of four", not other \\
\hline $\begin{array}{l}\text { Random sequence genera- } \\
\text { tion (selection bias) }\end{array}$ \\
\hline
\end{tabular}


Mustian 2009 (Continued)

$\begin{aligned} & \text { Allocation concealment } \\ & \text { (selection bias) }\end{aligned}$
Unclear risk Not stated

Blinding of outcome as- High risk Blinding not done

sessment (detection bias)

All outcomes

\begin{tabular}{l}
\hline $\begin{array}{l}\text { Incomplete outcome data } \\
\text { (attrition bias) }\end{array}$ \\
All outcomes risk
\end{tabular}

Selective reporting (re- Low risk $\quad$ Fatigue outcome reported
porting bias)

\begin{tabular}{l}
$\begin{array}{l}\text { Selective reporting (re- } \quad \text { Low risk } \\
\text { porting bias) }\end{array}$ \\
\hline
\end{tabular}

Mutrie 2007

\section{Study characteristics}

\begin{tabular}{ll}
\hline Methods & RCT; 2 groups, stratification for hospital and treatment \\
\hline Participants & 203 breast cancer patients during treatment \\
\hline Interventions & $\begin{array}{l}\text { Exercise: supervised 12-week group exercise } 2 \text { times/week, } 45 \text { mins/session at moderate intensity. Par- } \\
\text { ticipants encouraged to exercise once/week at home. } \\
\text { Control: usual care }\end{array}$ \\
\hline Outcomes & Quality of life \\
& Fatigue \\
& Depression \\
Mood \\
Body composition \\
Physical activity \\
12-minute walk
\end{tabular}

Notes

Methodological quality score: 3.

Main purpose of exercise: to improve quality of life

\section{Risk of bias}

\begin{tabular}{lll}
\hline Bias & Authors' judgement & Support for judgement \\
\hline $\begin{array}{l}\text { Random sequence genera- } \\
\text { tion (selection bias) }\end{array}$ & Low risk & $\begin{array}{l}\text { "Randomisation was done by telephone to an interactive voice response sys- } \\
\text { tem" }\end{array}$ \\
\hline $\begin{array}{l}\text { Allocation concealment } \\
\text { (selection bias) }\end{array}$ & Low risk & $\begin{array}{l}\text { "Randomisation was done by telephone to an interactive voice response sys- } \\
\text { tem" }\end{array}$ \\
\hline $\begin{array}{l}\text { Blinding of outcome as- } \\
\text { sessment (detection bias) } \\
\text { All outcomes }\end{array}$ & High risk & Blinding not done \\
\hline $\begin{array}{l}\text { Incomplete outcome data } \\
\text { (attrition bias) } \\
\text { All outcomes }\end{array}$ & Low risk & All participants were accounted for \\
\hline \hline
\end{tabular}

Exercise for the management of cancer-related fatigue in adults (Review) 
Mutrie 2007 (Continued)

Selective reporting (re- Low risk $\quad$ Fatigue outcome reported
porting bias)

Oh 2008

\section{Study characteristics}

\begin{tabular}{ll}
\hline Methods & RCT; 2 group; stratified by treatment (ongoing or complete) \\
\hline Participants & 18 cancer patients with various diagnoses and at various stages of treatment \\
\hline Interventions & $\begin{array}{l}\text { Exercise: Qigong, supervised groups, } 1 \text { to } 2 \text { sessions/week for } 8 \text { weeks, } 90 \text { mins/session and practice at } \\
\text { home for } 1 \text { hour/day }\end{array}$ \\
& Control: usual care, asked to refrain from joining a Qigong class \\
\hline Outcomes & Quality of life (including a fatigue sub scale) \\
& Symptom experience \\
Inflammation
\end{tabular}

Notes Methodological quality score: 2

Main purpose of exercise: to improve quality of life, reduce treatment symptoms and inflammation

\section{Risk of bias}

\begin{tabular}{|c|c|c|}
\hline Bias & Authors' judgement & Support for judgement \\
\hline $\begin{array}{l}\text { Random sequence genera- } \\
\text { tion (selection bias) }\end{array}$ & Low risk & "Randomization was done by a computer program" \\
\hline $\begin{array}{l}\text { Allocation concealment } \\
\text { (selection bias) }\end{array}$ & High risk & Not done \\
\hline $\begin{array}{l}\text { Blinding of outcome as- } \\
\text { sessment (detection bias) } \\
\text { All outcomes }\end{array}$ & High risk & Blinding not done \\
\hline $\begin{array}{l}\text { Incomplete outcome data } \\
\text { (attrition bias) } \\
\text { All outcomes }\end{array}$ & Low risk & All participants were accounted for \\
\hline $\begin{array}{l}\text { Selective reporting (re- } \\
\text { porting bias) }\end{array}$ & Low risk & Fatigue outcome reported \\
\hline
\end{tabular}

Oh 2010

\section{Study characteristics}

\begin{tabular}{lc}
\hline Methods & RCT; 2 group; stratified by treatment (ongoing or complete) \\
\hline Participants & 108 cancer patients with various diagnoses and at various stages of treatment \\
\hline \hline Exercise for the management of cancer-related fatigue in adults (Review) \\
Copyright $\odot 2012$ The Cochrane Collaboration. Published by John Wiley \& Sons, Ltd.
\end{tabular}

Copyright $\odot 2012$ The Cochrane Collaboration. Published by John Wiley \& Sons, Ltd. 
Oh 2010 (Continued)

Exercise: Qigong, supervised groups, 2 sessions/week for 10 weeks, 90 mins/session and practice at home for 30 minutes/day

Control: usual care, asked to refrain from joining a Qigong class

\begin{tabular}{ll}
\hline Outcomes & Fatigue \\
& Quality of life \\
Mood \\
Inflammation \\
\hline
\end{tabular}

Notes $\quad$ Methodological quality score: 2

Main purpose of exercise: to improve quality of life

\section{Risk of bias}

\begin{tabular}{|c|c|c|}
\hline Bias & Authors' judgement & Support for judgement \\
\hline $\begin{array}{l}\text { Random sequence genera- } \\
\text { tion (selection bias) }\end{array}$ & Low risk & "Randomization, by computer, was stratified by treatment at baseline" \\
\hline $\begin{array}{l}\text { Allocation concealment } \\
\text { (selection bias) }\end{array}$ & High risk & Not done \\
\hline $\begin{array}{l}\text { Blinding of outcome as- } \\
\text { sessment (detection bias) } \\
\text { All outcomes }\end{array}$ & High risk & Blinding not done \\
\hline $\begin{array}{l}\text { Incomplete outcome data } \\
\text { (attrition bias) } \\
\text { All outcomes }\end{array}$ & Low risk & All participants were accounted for \\
\hline
\end{tabular}

Selective reporting (re- Low risk $\quad$ Fatigue outcome reported

porting bias)

\section{Payne 2008}

\section{Study characteristics}

\begin{tabular}{|c|c|}
\hline Methods & $\mathrm{RCT} ; 2$ groups \\
\hline Participants & 18 patients with breast cancer \\
\hline Interventions & $\begin{array}{l}\text { Exercise: aerobic, unsupervised, home-based walking at a moderate intensity for } 20 \text { minutes, } 4 \text { times/ } \\
\text { week for } 12 \text { weeks } \\
\text { Control: usual care }\end{array}$ \\
\hline Outcomes & $\begin{array}{l}\text { Fatigue } \\
\text { Depression } \\
\text { Sleep disturbance } \\
\text { Biomarkers }\end{array}$ \\
\hline
\end{tabular}


Payne 2008 (Continued)

Exercise

Notes Methodological quality score: 2

Main purpose of exercise: to reduce fatigue, sleep disturbances and depressive symptoms

\section{Risk of bias}

\begin{tabular}{lll}
\hline Bias & Authors' judgement & Support for judgement \\
\hline $\begin{array}{l}\text { Random sequence genera- } \\
\text { tion (selection bias) }\end{array}$ & Unclear risk & "randomized" but method not described \\
\hline $\begin{array}{l}\text { Allocation concealment } \\
\text { (selection bias) }\end{array}$ & Unclear risk & Not stated \\
\hline $\begin{array}{l}\text { Blinding of outcome as- } \\
\text { sessment (detection bias) } \\
\text { All outcomes }\end{array}$ & High risk & Blinding not done \\
\hline $\begin{array}{l}\text { Incomplete outcome data } \\
\text { (attrition bias) } \\
\text { All outcomes }\end{array}$ & Unclear risk & Unclear \\
\hline $\begin{array}{l}\text { Selective reporting (re- } \\
\text { porting bias) }\end{array}$ & Low risk & \\
\hline
\end{tabular}

\section{Pinto 2003}

\section{Study characteristics}

\begin{tabular}{|c|c|c|}
\hline Methods & \multicolumn{2}{|l|}{ RCT; 2 groups } \\
\hline Participants & \multicolumn{2}{|c|}{24 stage 0 to II sedentary breast cancer patients post-treatment } \\
\hline Interventions & \multicolumn{2}{|c|}{$\begin{array}{l}\text { Exercise: } 60 \% \text { to } 70 \% \text { HRmax, supervised, } 3 \text { times/week for } 12 \text { weeks, increased up to } 10 \text {-min warm-up, } \\
\text { to } 30 \text {-min cardiovascular activity and } 10-\text { min cool down. Various activities included. } \\
\text { Control: wait-list, no intervention }\end{array}$} \\
\hline Outcomes & \multicolumn{2}{|c|}{$\begin{array}{l}\text { Mood (including anger, tension, depression, vigour, fatigue and confusion) } \\
\text { Positive and negative affect } \\
\text { Body esteem }\end{array}$} \\
\hline Notes & \multicolumn{2}{|c|}{$\begin{array}{l}\text { Methodological quality score: } 2 \\
\text { Main purpose of exercise: to reduce distress and improve body image and fitness }\end{array}$} \\
\hline \multicolumn{3}{|l|}{ Risk of bias } \\
\hline Bias & Authors' judgement & Support for judgement \\
\hline $\begin{array}{l}\text { Random sequence genera- } \\
\text { tion (selection bias) }\end{array}$ & Unclear risk & "randomized" but method not stated \\
\hline $\begin{array}{l}\text { Allocation concealment } \\
\text { (selection bias) }\end{array}$ & Unclear risk & Not stated \\
\hline
\end{tabular}


Pinto 2003 (Continued)

$\begin{array}{lll}\text { Blinding of outcome as- } & \text { High risk } \quad \text { Blinding not done } \\ \text { sessment (detection bias) } & \end{array}$

All outcomes

\begin{tabular}{lll}
\hline $\begin{array}{l}\text { Incomplete outcome data } \\
\text { (attrition bias) }\end{array}$ & Low risk & All participants were accounted for \\
All outcomes & \\
\hline $\begin{array}{l}\text { Selective reporting (re- } \\
\text { porting bias) }\end{array}$ & Low risk & Fatigue outcome reported \\
\hline
\end{tabular}

Pinto 2005

\section{Study characteristics}

\begin{tabular}{|c|c|}
\hline Methods & $\mathrm{RCT} ; 2$ groups, stratification for age, cancer stage and adjuvant therapy received \\
\hline Participants & 86 stage 0 to II sedentary breast cancer patients post-treatment \\
\hline Interventions & $\begin{array}{l}\text { Exercise: moderate-intensity home-based activities, } 55 \% \text { to } 65 \% \text { HRmax. } 10 \text { mins twice/week increas- } \\
\text { ing to } 30 \text { mins at least } 5 \text { days/week over } 12 \text { weeks. Weekly phone calls during exercise. } \\
\text { Control: weekly phone call to monitor symptoms }\end{array}$ \\
\hline Outcomes & $\begin{array}{l}\text { Body composition } \\
\text { Activity levels } \\
\text { 1-mile walk } \\
\text { Motivational readiness for exercise } \\
\text { Mood } \\
\text { Fatigue } \\
\text { Body esteem }\end{array}$ \\
\hline Notes & $\begin{array}{l}\text { Methodological quality score: } 2 \\
\text { Main purpose of exercise: to increase physical activity, fitness; improve mood, physical symptoms and } \\
\text { body esteem }\end{array}$ \\
\hline
\end{tabular}

\section{Risk of bias}

\begin{tabular}{|c|c|c|}
\hline Bias & Authors' judgement & Support for judgement \\
\hline $\begin{array}{l}\text { Random sequence genera- } \\
\text { tion (selection bias) }\end{array}$ & Unclear risk & "randomized" but method not stated \\
\hline $\begin{array}{l}\text { Allocation concealment } \\
\text { (selection bias) }\end{array}$ & Unclear risk & Not stated \\
\hline $\begin{array}{l}\text { Blinding of outcome as- } \\
\text { sessment (detection bias) } \\
\text { All outcomes }\end{array}$ & High risk & Blinding not done \\
\hline $\begin{array}{l}\text { Incomplete outcome data } \\
\text { (attrition bias) } \\
\text { All outcomes }\end{array}$ & Low risk & All participants were accounted for \\
\hline $\begin{array}{l}\text { Selective reporting (re- } \\
\text { porting bias) }\end{array}$ & Low risk & Fatigue outcome reported \\
\hline
\end{tabular}


Rogers 2009

\section{Study characteristics}

\begin{tabular}{ll}
\hline Methods & RCT; 2 groups \\
\hline Participants & 37 patients with breast cancer receiving hormone therapy, all other adjuvant therapy complete \\
\hline Interventions & $\begin{array}{l}\text { Exercise: aerobic walking, supervised session once/week for } 12 \text { weeks in an individual basis in addition } \\
\text { to home-based walking. Supervised sessions also included behaviour change counselling. Participants } \\
\text { aimed to achieve } 150 \text { minutes of walking/week. }\end{array}$ \\
Control: usual care plus received written material relating to physical activity
\end{tabular}

$\begin{array}{ll}\text { Outcomes } & \text { Fatigue } \\ \text { Aerobic fitness } & \text { Strength } \\ \text { Body composition } & \text { Physical activity } \\ \text { Diet } & \text { Endocrine symptoms } \\ \text { Cognitive function } \\ \text { Sleep dysfunction } \\ \text { Pain } \\ \text { Lower extremity function }\end{array}$

$\begin{array}{ll}\text { Notes } & \text { Methodological quality score: } 3 \\ & \text { Main purpose of exercise: to increase physical activity }\end{array}$

\section{Risk of bias}

\section{Bias}

Authors' judgement Support for judgement

Random sequence genera- Low risk "Randomization was computer generated"

tion (selection bias)

\begin{tabular}{lll}
\hline $\begin{array}{l}\text { Allocation concealment } \\
\text { (selection bias) }\end{array}$ & Unclear risk & $\begin{array}{l}\text { "...and kept in sealed envelopes until randomization" - not clear as envelopes } \\
\text { not stated as "opaque" }\end{array}$ \\
\hline $\begin{array}{l}\text { Blinding of outcome as- } \\
\text { sessment (detection bias) } \\
\text { All outcomes }\end{array}$ & High risk & Blinding not done \\
\hline
\end{tabular}

Incomplete outcome data Low risk $\quad$ All participants were accounted for
(attrition bias)

All outcomes

\begin{tabular}{l}
$\begin{array}{l}\text { Selective reporting (re- } \quad \text { Low risk } \\
\text { porting bias) }\end{array}$ \\
\hline
\end{tabular}


Santa Mina 2012

\section{Study characteristics}

\begin{tabular}{ll}
\hline Methods & RCT; 2 groups \\
\hline Participants & 10 patients with prostate cancer either during or post-androgen deprivation therapy \\
\hline Interventions & $\begin{array}{l}\text { Exercise (group): combined aerobic and resistance training in a supervised group for } 60 \text { minutes/ses- } \\
\text { sion, } 3 \text { times/week for } 8 \text { weeks. Aerobic intensity: } 70 \% \text { to } 85 \% \text { HRmax, resistance: } 6 \text { to } 12 \text { RM }\end{array}$ \\
& $\begin{array}{l}\text { Exercise (individual): combined aerobic and resistance training with a personal trainer for } 60 \text { min- } \\
\text { utes/session, } 3 \text { times/week for } 8 \text { weeks. Aerobic intensity: } 70 \% \text { to } 85 \% \text { HRmax, resistance: } 6 \text { to } 12 \text { RM }\end{array}$ \\
\hline Outcomes & Fatigue \\
& Quality of life \\
& Aerobic fitness \\
& Strength \\
& Balance \\
Body composition & Blood pressure \\
Patient satisfaction
\end{tabular}

Notes

Methodological quality score: 3

Main purpose of exercise: to reduce fatigue and improve quality of life

\section{Risk of bias}

\begin{tabular}{|c|c|c|}
\hline Bias & Authors' judgement & Support for judgement \\
\hline $\begin{array}{l}\text { Random sequence genera- } \\
\text { tion (selection bias) }\end{array}$ & Unclear risk & "randomized" but method not described \\
\hline $\begin{array}{l}\text { Allocation concealment } \\
\text { (selection bias) }\end{array}$ & Low risk & "Concealed...sequentially numbered opaque envelopes" \\
\hline $\begin{array}{l}\text { Blinding of outcome as- } \\
\text { sessment (detection bias) } \\
\text { All outcomes }\end{array}$ & High risk & Blinding not done \\
\hline $\begin{array}{l}\text { Incomplete outcome data } \\
\text { (attrition bias) } \\
\text { All outcomes }\end{array}$ & Low risk & All participants were accounted for \\
\hline $\begin{array}{l}\text { Selective reporting (re- } \\
\text { porting bias) }\end{array}$ & Low risk & Fatigue outcome reported \\
\hline
\end{tabular}

\section{Segal 2001a}

\section{Study characteristics}


Segal 2001a (Continued)

\begin{tabular}{ll} 
Methods & RCT; 3 group, stratified for adjuvant treatment, random numbers table \\
\hline Participants & 123 stage I to II breast cancer, within 2 weeks of commencing adjuvant therapy
\end{tabular}

Interventions Supervised exercise: 3 times per week progressive walking, further 2 times unsupervised. Unsupervised exercise: 5 times per week progressive walking at $50 \%$ to $60 \%$ maximal predicted oxygen uptake.

Control: usual care

\begin{tabular}{ll}
\hline Outcomes & HRQOL \\
& Fatigue \\
& Aerobic capacity \\
& Body composition
\end{tabular}

Notes Methodological quality score: 3

Main purpose of exercise: to improve physical function and HRQOL

\section{Risk of bias}

\begin{tabular}{lll}
\hline Bias & Authors' judgement & Support for judgement \\
\hline $\begin{array}{l}\text { Random sequence genera- } \\
\text { tion (selection bias) }\end{array}$ & Low risk & $\begin{array}{l}\text { "randomly assigned participants to one of three groups using a random num- } \\
\text { bers table" }\end{array}$ \\
\hline $\begin{array}{l}\text { Allocation concealment } \\
\text { (selection bias) }\end{array}$ & High risk & "A study coordinator revealed group assignment after baseline testing" \\
\hline $\begin{array}{l}\text { Blinding of outcome as- } \\
\text { sessment (detection bias) } \\
\text { All outcomes }\end{array}$ & High risk & Blinding not done \\
\hline $\begin{array}{l}\text { Incomplete outcome data } \\
\text { (attrition bias) } \\
\text { All outcomes }\end{array}$ & Low risk & All participants were accounted for \\
\hline $\begin{array}{l}\text { Selective reporting (re- } \\
\text { porting bias) }\end{array}$ & Low risk & Fatigue outcome reported \\
\hline
\end{tabular}

\section{Segal 2001b}

\section{Study characteristics}

\begin{tabular}{ll}
\hline Methods & See Segal 2001a \\
\hline Participants & See Segal 2001a \\
\hline Interventions & See Segal 2001a \\
\hline Outcomes & See Segal 2001a \\
\hline Notes & See Segal 2001a \\
\hline
\end{tabular}

\section{Risk of bias}


Segal 2001b (Continued)
Random sequence genera- Low risk
"randomly assigned participants to one of three groups using a random num- tion (selection bias)
bers table"

Allocation concealment High risk

(selection bias)

"A study coordinator revealed group assignment after baseline testing"

\begin{tabular}{lll}
\hline $\begin{array}{l}\text { Blinding of outcome as- } \\
\text { sessment (detection bias) } \\
\text { All outcomes }\end{array}$ & High risk & Blinding not done \\
\hline $\begin{array}{l}\text { Incomplete outcome data } \\
\begin{array}{l}\text { (attrition bias) } \\
\text { All outcomes }\end{array}\end{array}$ & Low risk & All participants were accounted for \\
\hline $\begin{array}{l}\text { Selective reporting (re- } \\
\text { porting bias) }\end{array}$ & Low risk & Fatigue outcome reported \\
\hline
\end{tabular}

\section{Segal 2003}

\section{Study characteristics}

\begin{tabular}{ll}
\hline Methods & RCT; 2 groups, random numbers table, stratification for centre and intent of treatment \\
\hline Participants & 155 prostate cancer patients, due to receive androgen deprivation therapy \\
\hline Interventions & $\begin{array}{l}\text { Exercise: individualised resistance training. } 9 \text { exercises at } 60 \% \text { to } 70 \% 1 \text { RM, } 3 \text { times/week for } 12 \text { weeks. } \\
\text { Control: wait list }\end{array}$ \\
\hline Outcomes & $\begin{array}{l}\text { Fatigue } \\
\text { HRQOL } \\
\text { Muscular fitness } \\
\text { Body composition }\end{array}$
\end{tabular}

$\begin{array}{ll}\text { Notes } & \text { Methodological quality score: } 2 \\ & \text { Main purpose of exercise: to improve quality of life and reduce fatigue }\end{array}$

\section{Risk of bias}

\begin{tabular}{lll}
\hline Bias & Authors' judgement & Support for judgement \\
\hline $\begin{array}{l}\text { Random sequence genera- } \\
\text { tion (selection bias) }\end{array}$ & Low risk & "Randomization, performed using a table of random numbers" \\
\hline $\begin{array}{l}\text { Allocation concealment } \\
\text { (selection bias) }\end{array}$ & Low risk & $\begin{array}{l}\text { "The treatment allocation was concealed from the study coordinator until } \\
\text { completion of baseline testing and stratification" }\end{array}$ \\
\hline $\begin{array}{l}\text { Blinding of outcome as- } \\
\text { sessment (detection bias) } \\
\text { All outcomes }\end{array}$ & High risk & Blinding not done \\
\hline $\begin{array}{l}\text { Incomplete outcome data } \\
\text { (attrition bias) } \\
\text { All outcomes }\end{array}$ & High risk & $\begin{array}{l}\text { Reasons for drop-out not provided and data not included within an inten- } \\
\text { tion-to-treat analysis. }\end{array}$ \\
\hline
\end{tabular}


Segal 2003 (Continued)
Selective reporting (re-
Low risk
Fatigue outcome reported porting bias)

Segal 2009a

\section{Study characteristics}

\begin{tabular}{|c|c|}
\hline Methods & $\mathrm{RCT} ; 3$ groups; stratified by intended duration of androgen deprivation therapy \\
\hline Participants & 212 patients with prostate cancer receiving radiotherapy \\
\hline \multirow[t]{3}{*}{ Interventions } & $\begin{array}{l}\text { Exercise (resistance): supervised, } 3 \text { times/week for } 24 \text { weeks. } 2 \text { times } 8 \text { to } 12 \text { reps of } 10 \text { exercises at } 60 \% \\
\text { to } 70 \% \text { estimated } 1 \text { RM, increased by } 5 \mathrm{lb} \text { when }>12 \text { reps completed. }\end{array}$ \\
\hline & $\begin{array}{l}\text { Exercise (aerobic): supervised, } 3 \text { times/week for } 24 \text { weeks. Cycle ergometer, treadmill or elliptical train- } \\
\text { er, } 15 \text { minutes/session initially, increased by } 5 \text { minutes every } 3 \text { weeks up to } 45 \text { minutes; started at } 50 \% \\
\text { to } 60 \% \text { of } \mathrm{VO}_{2} \text { peak for } 4 \text { weeks then } 70 \% \text { to } 75 \% \text { for weeks } 5 \text { to } 24 \text {. }\end{array}$ \\
\hline & Control: usual care, asked not to initiate exercise and offered a post-study intervention \\
\hline
\end{tabular}

\begin{tabular}{ll}
\hline Outcomes & Fatigue \\
& Quality of life \\
Aerobic fitness & Strength \\
Body composition & Blood profile \\
& Prostate specific antigen and testosterone
\end{tabular}

$\begin{array}{ll}\text { Notes } & \text { Methodological quality score: } 3 \\ & \text { Main purpose of exercise: to reduce fatigue, improve cancer-specific quality of life, physical fitness, } \\ & \text { body composition, prostate specific antigen, testosterone and serum lipid levels }\end{array}$

\section{Risk of bias}

\begin{tabular}{lll}
\hline Bias & Authors' judgement & Support for judgement \\
\hline $\begin{array}{l}\text { Random sequence genera- } \\
\text { tion (selection bias) }\end{array}$ & Low risk & "randomly assigned...using computer-generated numbers" \\
\hline $\begin{array}{l}\text { Allocation concealment } \\
\text { (selection bias) }\end{array}$ & Low risk & $\begin{array}{l}\text { Central random assignment was used, with allocation concealment before as- } \\
\text { signment. To ensure blinding of the research co-ordinator, an exercise special- } \\
\text { ist handled the random assignments" }\end{array}$ \\
\hline
\end{tabular}

Blinding of outcome as- High risk Blinding not done

sessment (detection bias)

All outcomes

Incomplete outcome data Low risk All participants were accounted for
(attrition bias)
All outcomes


Segal 2009a (Continued)
Selective reporting (re-
Fatigue outcome reported porting bias)

Segal 2009b

\section{Study characteristics}

\begin{tabular}{ll}
\hline Methods & See Segal 2009a \\
\hline Participants & See Segal 2009a \\
\hline Interventions & See Segal 2009a \\
\hline Outcomes & See Segal 2009a \\
\hline Notes & See Segal 2009a
\end{tabular}

\section{Risk of bias}

\begin{tabular}{lll}
\hline Bias & Authors' judgement & Support for judgement \\
\hline $\begin{array}{l}\text { Random sequence genera- } \\
\text { tion (selection bias) }\end{array}$ & Low risk & "randomly assigned...using computer-generated numbers" \\
\hline $\begin{array}{l}\text { Allocation concealment } \\
\text { (selection bias) }\end{array}$ & Low risk & $\begin{array}{l}\text { Central random assignment was used, with allocation concealment before as- } \\
\text { signment. To ensure blinding of the research co-ordinator, an exercise special- } \\
\text { ist handled the random assignments" }\end{array}$ \\
\hline
\end{tabular}

\begin{tabular}{lll}
\hline Blinding of outcome as- & High risk $\quad$ Blinding not done
\end{tabular}

sessment (detection bias)

All outcomes

Incomplete outcome data Low risk All participants were accounted for
(attrition bias)

Selective reporting (re- Low risk $\quad$ Fatigue outcome reported
porting bias)

\section{Sequeira 2012}

\section{Study characteristics}

\begin{tabular}{ll}
\hline Methods & RCT; 2 groups \\
\hline Participants & 20 patients with breast cancer post-treatment \\
\hline Interventions & $\begin{array}{l}\text { Exercise: exercise programme in addition to physiotherapy, twice per week supervised in the hospital } \\
\text { and once/week at home } \\
\text { Control: usual physiotherapy }\end{array}$ \\
\hline Outcomes & Quality of life (including fatigue)
\end{tabular}


Sequeira 2012 (Continued)

Physical activity level

Body mass index

Side effects of cancer therapy

$\begin{array}{ll}\text { Notes } & \text { Methodological quality score: } 2 \\ & \text { Main purpose of exercise: to increase physical activity level }\end{array}$

\section{Risk of bias}

\section{Bias}

Authors' judgement Support for judgement

Random sequence genera- Unclear risk "randomized" but method not described tion (selection bias)

\begin{tabular}{ll}
\hline $\begin{array}{l}\text { Allocation concealment } \\
\text { (selection bias) }\end{array}$ & Unclear risk
\end{tabular}

Blinding of outcome as- Unclear risk Blinding unclear
sessment (detection bias)

All outcomes

\begin{tabular}{lll}
$\begin{array}{l}\text { Incomplete outcome data } \\
\text { (attrition bias) } \\
\text { All outcomes }\end{array}$ & Unclear risk & Unclear \\
\hline $\begin{array}{l}\text { Selective reporting (re- } \\
\text { porting bias) }\end{array}$ & Low risk & Fatigue outcome reported
\end{tabular}

Shelton 2009

\section{Study characteristics}

\begin{tabular}{ll}
\hline Methods & RCT; 2 groups \\
\hline Participants & 53 patients with leukaemia within 6 months of allogenic stem cell transplant \\
\hline Interventions & $\begin{array}{l}\text { Exercise (supervised): combined aerobic and resistance training } 3 \text { times/week for } 4 \text { weeks. Individu- } \\
\text { alised, aerobic exercise included upper and lower extremity ergometry and treadmill for at least } 20 \\
\text { minutes at } 60 \% \text { to } 75 \% \text { age predicted HRmax. Various resistance exercises, } 1 \text { to } 3 \text { sets of } 10 \text { reps with in- } \\
\text { tensity determined by fatigue. Intensity of aerobic and resistance training increased every third session } \\
\text { unless extreme fatigue was reported. } \\
\text { Exercise (unsupervised): combined aerobic (walking) and resistance training for } 4 \text { weeks. Walking time } \\
\text { increased to } 30 \text { mins over the } 4 \text { weeks. Various resistance exercises } 1 \text { to } 3 \text { sets of } 10 \text { to } 15 \text { reps. Intensity } \\
\text { of the exercise was not reported. }\end{array}$ \\
\hline Futcomes & $\begin{array}{l}\text { Fatigue } \\
\text { Perobic capacity }\end{array}$ \\
\hline
\end{tabular}

Main purpose of exercise: to improve functional outcome 
Shelton 2009 (Continued)

Risk of bias

\begin{tabular}{lll}
\hline Bias & Authors' judgement & Support for judgement \\
\hline $\begin{array}{l}\text { Random sequence genera- } \\
\text { tion (selection bias) }\end{array}$ & Unclear risk & "randomly assigned" but method not described \\
\hline $\begin{array}{l}\text { Allocation concealment } \\
\text { (selection bias) }\end{array}$ & Unclear risk & Not stated \\
\hline $\begin{array}{l}\text { Blinding of outcome as- } \\
\text { sessment (detection bias) } \\
\text { All outcomes }\end{array}$ & High risk & Blinding not done \\
\hline $\begin{array}{l}\text { Incomplete outcome data } \\
\text { (attrition bias) } \\
\text { All outcomes }\end{array}$ & Unclear risk & Unclear \\
\hline $\begin{array}{l}\text { Selective reporting (re- } \\
\text { porting bias) }\end{array}$ & Low risk & \\
\hline
\end{tabular}

Thorsen 2005

\section{Study characteristics}

\begin{tabular}{ll}
\hline Methods & RCT; 2 groups, stratification for gender and diagnosis, randomised by computer \\
\hline Participants & 111 various cancer diagnoses, 1 month following chemotherapy at baseline \\
\hline Interventions & $\begin{array}{l}\text { Exercise: personalised home-based training programme. Patient selected mode of exercise. } 14 \text { weeks, } \\
\text { twice/week for at least } 30 \text { minutes per session. Intensity: } 13 \text { to } 15 \text { on Borg scale or } 60 \% \text { to } 70 \% \text { HRmax } \\
\text { based on patient choice. Contacted fortnightly. } \\
\text { Control: no intervention }\end{array}$ \\
\hline
\end{tabular}

\begin{tabular}{|c|c|c|}
\hline Outcomes & \multicolumn{2}{|c|}{$\begin{array}{l}\text { Physical function } \\
\text { HRQOL (including physical and emotional function and fatigue) } \\
\text { Anxiety } \\
\text { Depression } \\
\text { Activity level }\end{array}$} \\
\hline Notes & \multicolumn{2}{|c|}{$\begin{array}{l}\text { Methodological quality score: } 2 \\
\text { Main purpose of exercise: to improve cardiorespiratory fitness, mental distress and HRQOL }\end{array}$} \\
\hline \multicolumn{3}{|l|}{ Risk of bias } \\
\hline Bias & Authors' judgement & Support for judgement \\
\hline $\begin{array}{l}\text { Random sequence genera- } \\
\text { tion (selection bias) }\end{array}$ & Low risk & $\begin{array}{l}\text { "randomly assigned...The... Hospital was responsible for the computerized ran- } \\
\text { dom assignment" }\end{array}$ \\
\hline $\begin{array}{l}\text { Allocation concealment } \\
\text { (selection bias) }\end{array}$ & Unclear risk & Not stated \\
\hline $\begin{array}{l}\text { Blinding of outcome as- } \\
\text { sessment (detection bias) }\end{array}$ & High risk & Blinding not done \\
\hline
\end{tabular}


Thorsen 2005 (Continued)

All outcomes

\begin{tabular}{|c|c|c|}
\hline $\begin{array}{l}\text { Incomplete outcome data } \\
\text { (attrition bias) }\end{array}$ & High risk & $\begin{array}{l}\text { Drop-outs were not accounted for and unclear how intention-to-treat was } \\
\text { analysis was undertaken }\end{array}$ \\
\hline
\end{tabular}

All outcomes

analysis was undertaken

Selective reporting (re- Low risk $\quad$ Fatigue outcome reported
porting bias)

porting bias)

van Weert 2010

\section{Study characteristics}

\begin{tabular}{ll}
\hline Methods & RCT; 3 groups, wait list control recruited outside the randomisation process \\
\hline Participants & $\begin{array}{l}136 \text { cancer patients at least } 3 \text { months following final treatment for cancer. In addition data from } 60 \text { pa- } \\
\text { tients were incorporated to provide a historical control (not reported here). }\end{array}$
\end{tabular}

Interventions Exercise: combined aerobic and strength training delivered through 12 1-hour individually supervised and 12 1-hour group sports sessions over 12 weeks. Individual aerobic training target was $40 \%$ to $50 \%$ HRmax for 4 weeks, increased to $50 \%$ to $80 \%$ HRmax during the remaining 8 weeks. Resistance training started at $30 \%$ of $1-\mathrm{RM}$ and increased to $60 \%$ by week 12 .

Comparison: exercise as above in combination with 12 hours of cognitive behavioural therapy

\begin{tabular}{|c|c|c|}
\hline Outcomes & $\begin{array}{l}\text { Fatigue } \\
\text { Quality of life }\end{array}$ & Quality of life \\
\hline Notes & \multicolumn{2}{|c|}{$\begin{array}{l}\text { Methodological quality score: } 3 \\
\text { Main purpose of exercise: to reduce fatigue, improve quality of life and physical function }\end{array}$} \\
\hline \multicolumn{3}{|l|}{ Risk of bias } \\
\hline Bias & Authors' judgement & Support for judgement \\
\hline $\begin{array}{l}\text { Random sequence genera- } \\
\text { tion (selection bias) }\end{array}$ & Unclear risk & $\begin{array}{l}\text { "Randomization was conducted at the group level by an independent re- } \\
\text { searcher using a randomization list" }\end{array}$ \\
\hline $\begin{array}{l}\text { Allocation concealment } \\
\text { (selection bias) }\end{array}$ & Unclear risk & Not stated \\
\hline $\begin{array}{l}\text { Blinding of outcome as- } \\
\text { sessment (detection bias) } \\
\text { All outcomes }\end{array}$ & High risk & Blinding not done \\
\hline $\begin{array}{l}\text { Incomplete outcome data } \\
\text { (attrition bias) } \\
\text { All outcomes }\end{array}$ & Low risk & All participants were accounted for \\
\hline $\begin{array}{l}\text { Selective reporting (re- } \\
\text { porting bias) }\end{array}$ & Low risk & Fatigue outcome reported \\
\hline
\end{tabular}


Windsor 2004

\section{Study characteristics}

\begin{tabular}{ll}
\hline Methods & RCT; 2 groups, independent telephone randomisation service \\
\hline Participants & 66 men with localised prostate carcinoma on waiting list for radical conformed radiotherapy \\
\hline Interventions & $\begin{array}{l}\text { Exercise: home-based walking } 60 \% \text { to } 70 \% \text { HRmax, } 30 \text { mins/session at least } 3 \text { times/week during radio- } \\
\text { therapy } \\
\text { Control: no intervention } \\
\text { Both groups contacted weekly }\end{array}$ \\
\hline Outcomes & $\begin{array}{l}\text { Fatigue } \\
\text { Physical function } \\
\text { Exercise adherence }\end{array}$ \\
\hline
\end{tabular}

$\begin{array}{ll}\text { Notes } & \text { Methodological quality score: } 3 \\ \text { Main purpose of exercise: to reduce fatigue and prevent deterioration of physical function }\end{array}$

\section{Risk of bias}

\begin{tabular}{lll}
\hline Bias & Authors' judgement & Support for judgement \\
\hline $\begin{array}{l}\text { Random sequence genera- } \\
\text { tion (selection bias) }\end{array}$ & Low risk & $\begin{array}{l}\text { "Patients were randomized to trial group by telephone call to the Scottish } \\
\text { Cancer Therapy Network randomization line before baseline tests were per- } \\
\text { formed" }\end{array}$ \\
\hline $\begin{array}{l}\text { Allocation concealment } \\
\text { (selection bias) }\end{array}$ & Low risk & $\begin{array}{l}\text { "Patients were randomized to trial group by telephone call to the Scottish } \\
\text { Cancer Therapy Network randomization line before baseline tests were per- } \\
\text { formed" }\end{array}$ \\
\hline $\begin{array}{l}\text { Blinding of outcome as- } \\
\text { sessment (detection bias) } \\
\text { All outcomes }\end{array}$ & High risk & Blinding not done \\
\hline $\begin{array}{l}\text { Incomplete outcome data } \\
\text { (attrition bias) }\end{array}$ & Unclear risk & $\begin{array}{l}\text { Follow-up data were not available for 1 participant that withdrew; no inten- } \\
\text { till outcomes }\end{array}$ \\
\hline $\begin{array}{l}\text { Selective reporting (re- } \\
\text { porting bias) }\end{array}$ & Low risk & Fatigue outcome reported analysis \\
\hline
\end{tabular}

Yuen 2007a

\section{Study characteristics}

\begin{tabular}{ll}
\hline Methods & RCT; 3 groups \\
\hline Participants & 22 patients with breast cancer \\
\hline Interventions & $\begin{array}{l}\text { Exercise (aerobic): home-based walking or alternative aerobic exercise at a Borg rating of } 10 \text { to } 13 \text { (fair- } \\
\text { ly light to somewhat hard) for } 20 \text { to } 30 \text { minutes, } 3 \text { times/week for } 12 \text { weeks }\end{array}$ \\
& $\begin{array}{l}\text { Exercise (resistance): home-based, } 8 \text { exercises on non-consecutive days. One set of each exercise in } \\
\text { weeks } 1 \text { to } 3,2 \text { sets in weeks } 4 \text { to } 6 \text { and } 3 \text { sets in week } 7 \text { onwards. } 8 \text { to } 12 \text { reps per exercise. Once } 12 \text { reps } \\
\text { could be repeated with good form resistance was increased. Advised to exercise at a Borg rating or } 10 \\
\text { to } 13 \text { (fairly light to somewhat hard). }\end{array}$ \\
\hline
\end{tabular}


Yuen 2007a (Continued)

Control: advised to continue normal activities

\begin{tabular}{|c|c|c|}
\hline Outcomes & \multicolumn{2}{|l|}{$\begin{array}{l}\text { Fatigue } \\
\text { Aerobic capacity }\end{array}$} \\
\hline Notes & \multicolumn{2}{|c|}{$\begin{array}{l}\text { Methodological quality score: } 1 \\
\text { Main purpose of exercise: to reduce fatigue }\end{array}$} \\
\hline \multicolumn{3}{|l|}{ Risk of bias } \\
\hline Bias & Authors' judgement & Support for judgement \\
\hline $\begin{array}{l}\text { Random sequence genera- } \\
\text { tion (selection bias) }\end{array}$ & Low risk & $\begin{array}{l}\text { "participants were assigned, based on computer generated random sequence, } \\
\text { to one of three groups" }\end{array}$ \\
\hline $\begin{array}{l}\text { Allocation concealment } \\
\text { (selection bias) }\end{array}$ & Unclear risk & Not stated \\
\hline $\begin{array}{l}\text { Blinding of outcome as- } \\
\text { sessment (detection bias) } \\
\text { All outcomes }\end{array}$ & High risk & Blinding not done \\
\hline $\begin{array}{l}\text { Incomplete outcome data } \\
\text { (attrition bias) } \\
\text { All outcomes }\end{array}$ & High risk & $\begin{array}{l}\text { Intention-to-treat analysis not performed and reasons for drop-out not provid- } \\
\text { ed }\end{array}$ \\
\hline $\begin{array}{l}\text { Selective reporting (re- } \\
\text { porting bias) }\end{array}$ & Low risk & Fatigue outcome reported \\
\hline
\end{tabular}

Yuen 2007b

\section{Study characteristics}

\begin{tabular}{ll}
\hline Methods & See Yuen 2007a \\
\hline Participants & See Yuen 2007a \\
\hline Interventions & See Yuen 2007a \\
\hline Outcomes & See Yuen 2007a \\
\hline Notes & See Yuen 2007a
\end{tabular}

\section{Risk of bias}

\begin{tabular}{lll}
\hline Bias & Authors' judgement & Support for judgement \\
\hline $\begin{array}{l}\text { Random sequence genera- } \\
\text { tion (selection bias) }\end{array}$ & Low risk & $\begin{array}{l}\text { "participants were assigned, based on computer generated random sequence, } \\
\text { to one of three groups" }\end{array}$ \\
\hline $\begin{array}{l}\text { Allocation concealment } \\
\text { (selection bias) }\end{array}$ & Unclear risk & Not stated \\
\hline $\begin{array}{l}\text { Blinding of outcome as- } \\
\text { sessment (detection bias) }\end{array}$ & High risk & Blinding not done \\
\hline
\end{tabular}


Yuen 2007b (Continued)

All outcomes

\begin{tabular}{lll}
\hline $\begin{array}{l}\text { Incomplete outcome data } \\
\text { (attrition bias) } \\
\text { All outcomes }\end{array}$ & High risk & $\begin{array}{l}\text { Intention-to-treat analysis not performed and reasons for drop-out not provid- } \\
\text { ed }\end{array}$ \\
\hline $\begin{array}{l}\text { Selective reporting (re- } \\
\text { porting bias) }\end{array}$ & Low risk & Fatigue outcome reported \\
\hline
\end{tabular}

CCT: controlled clinical trial

HR: heart rate

HRmax: maximum heart rate

HRQOL: health-related quality of life

$\mathrm{RCT}$ : randomised controlled trial

$\mathrm{RM}$ : repetition maximum

$\mathrm{VO}_{2}$ : an indicator of cardio-respiratory endurance and aerobic fitness

Characteristics of excluded studies [ordered by study ID]

\begin{tabular}{|c|c|}
\hline Study & Reason for exclusion \\
\hline Aghili 2007 & Not a randomised controlled trial \\
\hline Barinow-Wojewódzki 2008 & Not a randomised controlled trial \\
\hline Barsevick 2004 & No exercise intervention \\
\hline Battaglini 2007 & Outcomes reported do not meet the study inclusion criteria \\
\hline Berglund 1994 & Outcomes reported do not meet the study inclusion criteria \\
\hline Buss 2010 & Not a randomised controlled trial \\
\hline Cella 2004 & No clinical trial; review of studies \\
\hline Coleman 2003b & Outcomes reported do not meet the study inclusion criteria \\
\hline Coleman 2008 & Outcomes reported do not meet the study inclusion criteria \\
\hline Culos-Reed 2007 & Not a randomised controlled trial \\
\hline Decker 1989 & Not a randomised controlled trial \\
\hline Dimeo 1996 & Not a randomised controlled trial \\
\hline Dimeo 1997a & Not a randomised controlled trial \\
\hline Dimeo 1997b & Outcomes reported do not meet the study inclusion criteria \\
\hline Dimeo 2008 & Not a randomised controlled trial \\
\hline Fillion 2008 & Multimodal intervention therefore effects may not be attributed specifically to physical exercise \\
\hline Goedendorp 2010 & Intervention did not meet study inclusion criteria \\
\hline
\end{tabular}




\begin{tabular}{|c|c|}
\hline Study & Reason for exclusion \\
\hline Hansen 2009 & Not a randomised controlled trial \\
\hline Hartvig 2006 & Intervention did not meet study inclusion criteria \\
\hline Hayes 2004 & Outcomes reported do not meet the study inclusion criteria \\
\hline Hsieh 2008 & Not a randomised controlled trial \\
\hline Jarden 2009 & Intervention did not meet study inclusion criteria. \\
\hline Kim 2005 & Intervention did not meet study inclusion criteria \\
\hline Kim 2009 & Outcomes reported do not meet the study inclusion criteria \\
\hline Köhler 2008 & Not a randomised controlled trial \\
\hline MacVicar 1989 & Outcomes reported do not meet the study inclusion criteria \\
\hline Mock 2001 & Results not based upon original group allocation \\
\hline Oldervoll 2003 & Not a randomised controlled trial \\
\hline Ozalevli 2010 & Not a randomised controlled trial \\
\hline Pickett 2002 & Outcomes reported do not meet the study inclusion criteria \\
\hline Poorkiani 2010 & Multimodal intervention therefore effects may not be attributed specifically to physical exercise \\
\hline Riesenberg 2010 & Not a randomised controlled trial \\
\hline Rummans 2006 & Multimodal intervention therefore effects may not be attributed specifically to physical exercise \\
\hline Schneider 2007a & Not a randomised controlled trial \\
\hline Schneider 2007b & Not a randomised controlled trial \\
\hline Schneider 2007c & Not a randomised controlled trial \\
\hline Schwartz 1999 & Not a randomised controlled trial \\
\hline Schwartz 2000a & Not a randomised controlled trial \\
\hline Schwartz 2000b & Not a randomised controlled trial \\
\hline Schwartz 2001 & Not a randomised controlled trial \\
\hline Schwartz 2002 & Not a randomised controlled trial \\
\hline Sprod 2010 & Not a randomised controlled trial \\
\hline Turner 2004 & Not a randomised controlled trial \\
\hline Vadiraja 2009 & Outcomes reported do not meet the study inclusion criteria \\
\hline Watson 2004 & No clinical trial, literature review \\
\hline
\end{tabular}




\section{Study}

Wilson 2005

\section{Reason for exclusion}

Not a randomised controlled trial

\section{Characteristics of ongoing studies [ordered by study ID]}

Fisher-Schlombs 2010

\begin{tabular}{ll}
\hline Study name & $\begin{array}{l}\text { A pilot study of a home-based exercise intervention for adult patients with acute myeloid } \\
\text { leukaemia }\end{array}$ \\
\hline Methods & RCT \\
\hline Participants & Post-treatment acute myeloid leukaemia patients \\
\hline Interventions & 12-week home-based exercise programme \\
\hline Outcomes & Fitness, quality of life, fatigue, anxiety and depression \\
\hline Starting date & \\
\hline Contact information & Shabbir M.H. Alibhai: shabbir.alibhai@uhn.ca \\
\hline Notes &
\end{tabular}

\section{Santa Mina 2010}

\begin{tabular}{ll}
\hline Study name & Aerobic versus resistance exercise training for prostate cancer patients on ADT \\
\hline Methods & RCT \\
\hline Participants & Prostate cancer patients receiving ADT \\
\hline Interventions & Aerobic versus resistance exercise \\
\hline Outcomes & $\begin{array}{l}\text { Primary outcomes include fatigue, HRQOL and exercise adherence. Secondary outcomes include } \\
\text { aerobic and musculoskeletal fitness, body composition and biomarkers associated with tumorige- } \\
\text { nesis. }\end{array}$ \\
\hline Starting date & Daniel Santa Mina: dstamina@gmail.com \\
\hline Contact information & \\
\hline Notes &
\end{tabular}

ADT: androgen deprivation therapy HRQOL: health-related quality of life RCT: randomised controlled trial

\section{DATA AND ANALYSES}


Comparison 1. Fatigue: all data

\begin{tabular}{lllll}
\hline Outcome or subgroup title & No. of studies & $\begin{array}{l}\text { No. of partici- } \\
\text { pants }\end{array}$ & Statistical method & Effect size \\
\hline $\begin{array}{l}\text { 1.1 Exercise versus no exercise control; } \\
\text { post-test means }\end{array}$ & 38 & 2646 & $\begin{array}{l}\text { Std. Mean Difference (IV, Ran- } \\
\text { dom, 95\% Cl) }\end{array}$ & $\begin{array}{l}-0.27[-0.37, \\
-0.17]\end{array}$ \\
\hline
\end{tabular}

Analysis 1.1. Comparison 1: Fatigue: all data, Outcome 1: Exercise versus no exercise control; post-test means

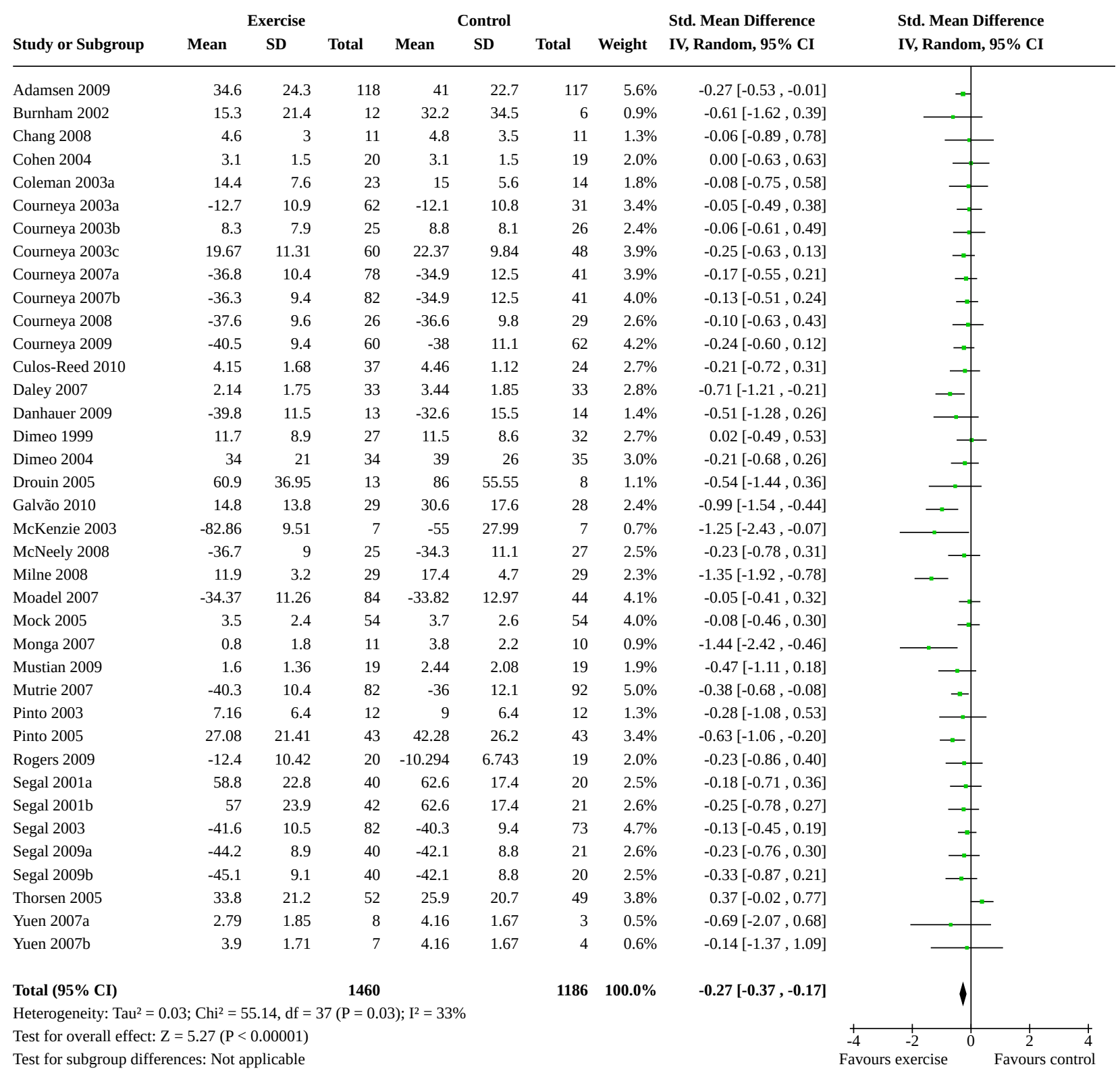


Comparison 2. Fatigue: during anti-cancer therapy

\begin{tabular}{lllll}
\hline Outcome or subgroup title & No. of studies & $\begin{array}{l}\text { No. of partici- } \\
\text { pants }\end{array}$ & Statistical method & Effect size \\
\hline $\begin{array}{l}\text { 2.1 Exercise versus no exercise control; } \\
\text { post-test means }\end{array}$ & 18 & 1456 & $\begin{array}{l}\text { Std. Mean Difference (IV, Ran- } \\
\text { dom, 95\% Cl) }\end{array}$ & $\begin{array}{l}-0.23[-0.33, \\
-0.12]\end{array}$ \\
\hline
\end{tabular}

Analysis 2.1. Comparison 2: Fatigue: during anti-cancer therapy, Outcome 1: Exercise versus no exercise control; post-test means

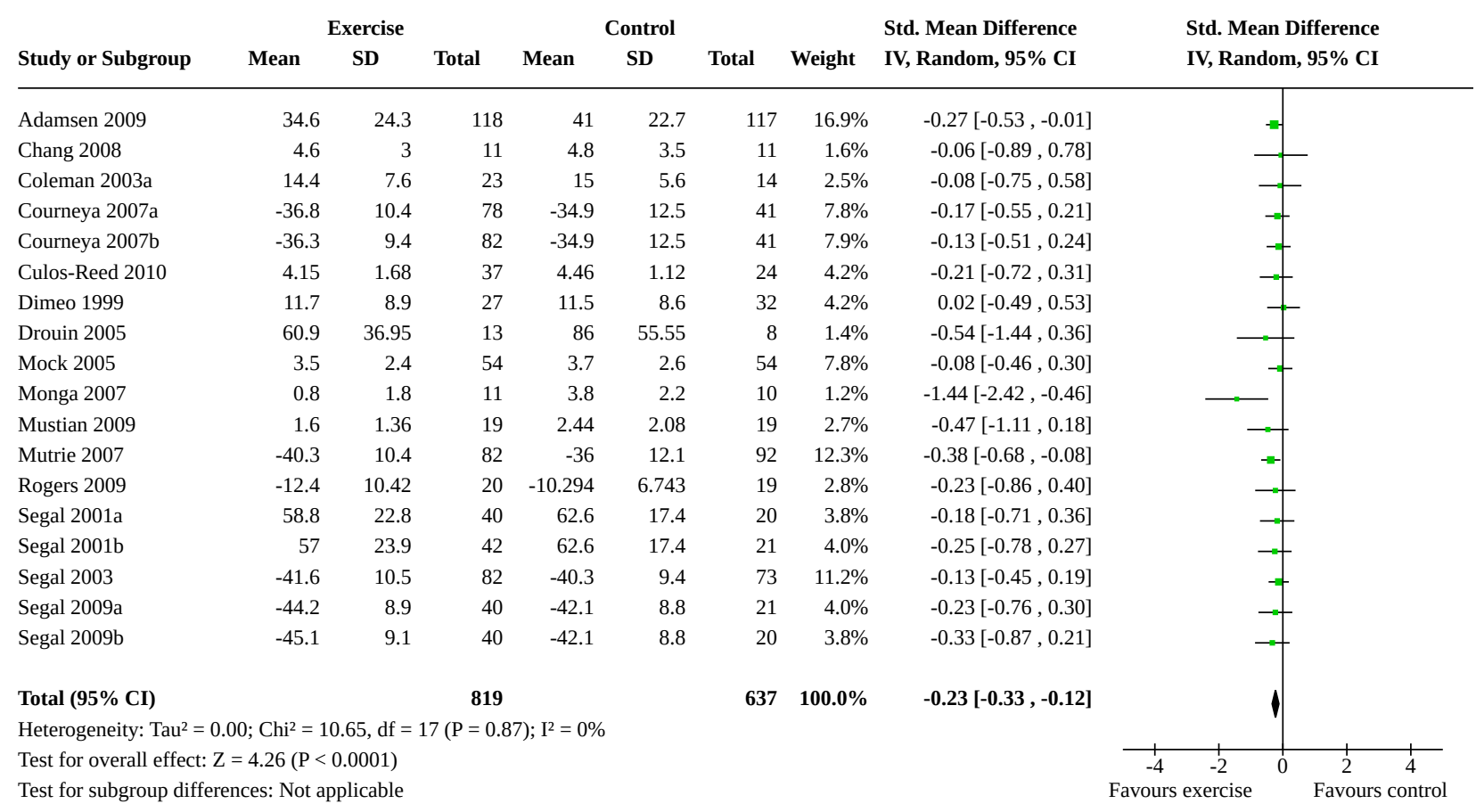

Comparison 3. Fatigue: post anti-cancer therapy

\begin{tabular}{lllll}
\hline Outcome or subgroup title & No. of studies & $\begin{array}{l}\text { No. of partici- } \\
\text { pants }\end{array}$ & Statistical method & Effect size \\
\hline $\begin{array}{l}\text { 3.1 Exercise versus no exercise con- } \\
\text { trol }\end{array}$ & 10 & 539 & $\begin{array}{l}\text { Std. Mean Difference (IV, Ran- } \\
\text { dom, 95\% Cl) }\end{array}$ & $\begin{array}{l}-0.44[-0.79, \\
-0.09]\end{array}$ \\
\hline
\end{tabular}


Analysis 3.1. Comparison 3: Fatigue: post anti-cancer therapy, Outcome 1: Exercise versus no exercise control

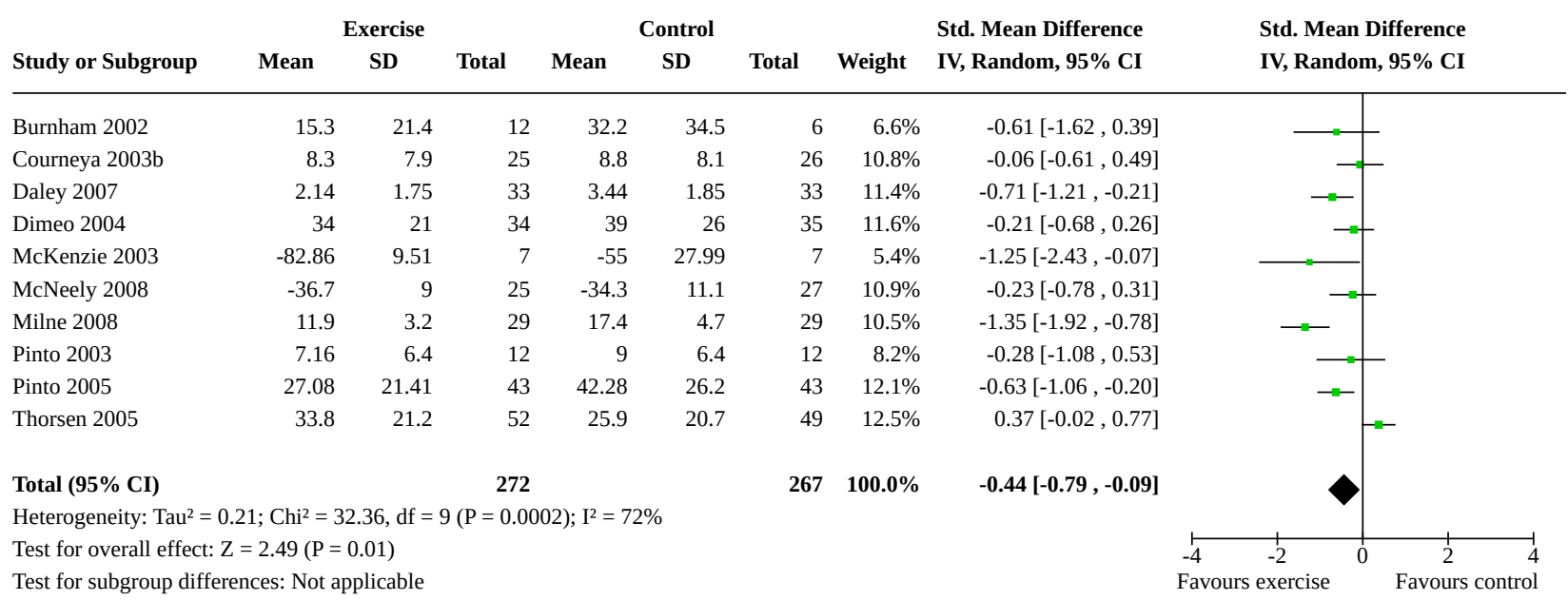

\section{Comparison 4. Fatigue: breast cancer}

\begin{tabular}{lllll}
\hline Outcome or subgroup title & No. of studies & $\begin{array}{l}\text { No. of partici- } \\
\text { pants }\end{array}$ & Statistical method & Effect size \\
\hline $\begin{array}{l}4.1 \text { Exercise versus no intervention } \\
\text { control; post-test means }\end{array}$ & 18 & 1183 & $\begin{array}{l}\text { Std. Mean Difference (IV, Ran- } \\
\text { dom, } 95 \% \text { Cl) }\end{array}$ & $\begin{array}{l}-0.35[-0.51, \\
-0.19]\end{array}$ \\
\hline
\end{tabular}

\section{Analysis 4.1. Comparison 4: Fatigue: breast cancer, Outcome 1: Exercise versus no intervention control; post-test means}

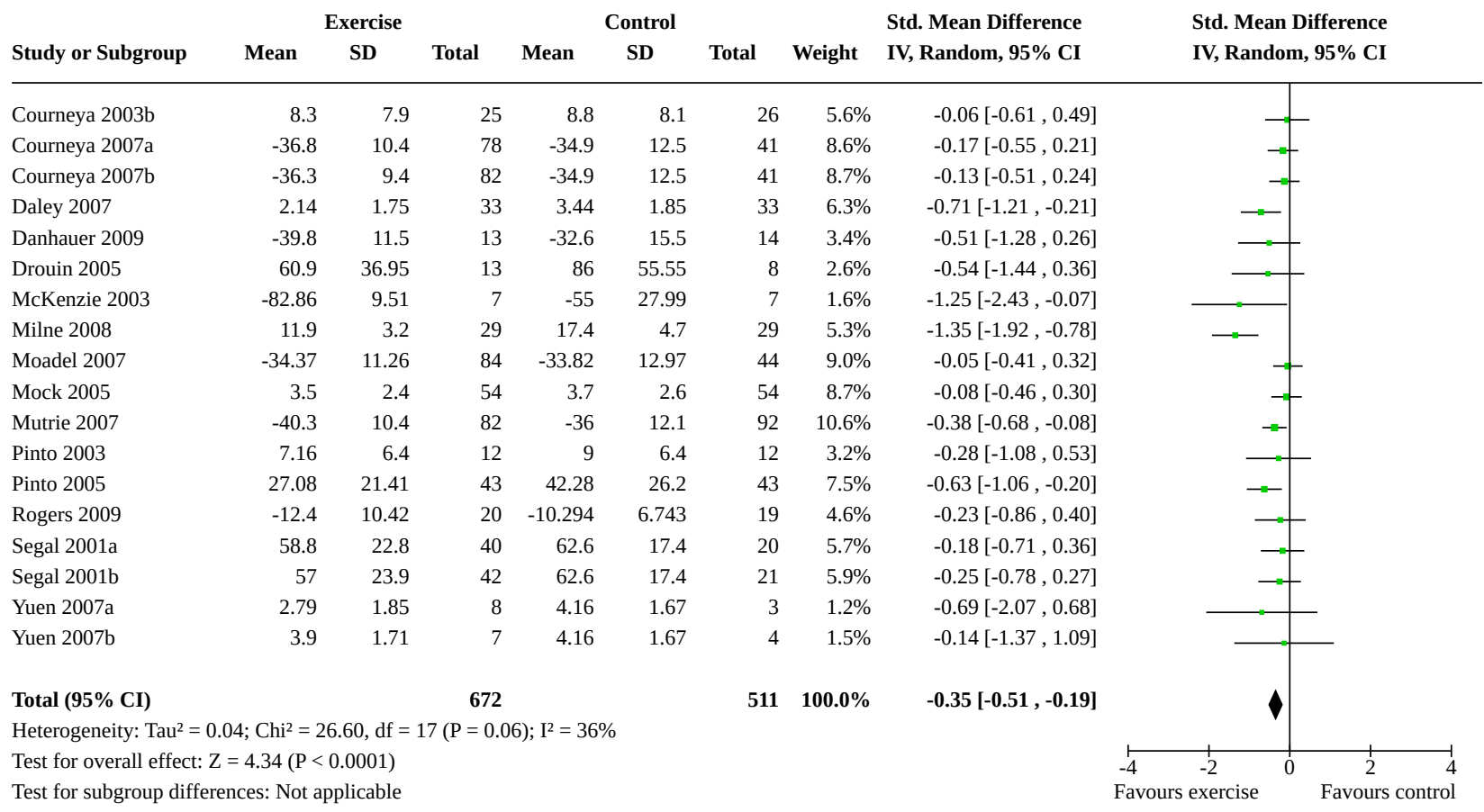


Comparison 5. Fatigue: prostate cancer

\begin{tabular}{|c|c|c|c|c|}
\hline Outcome or subgroup title & No. of studies & $\begin{array}{l}\text { No. of partici- } \\
\text { pants }\end{array}$ & Statistical method & Effect size \\
\hline $\begin{array}{l}\text { 5.1 Exercise versus no exercise control; } \\
\text { post-test means }\end{array}$ & 6 & 415 & $\begin{array}{l}\text { Std. Mean Difference (IV, } \\
\text { Random, } 95 \% \mathrm{CI} \text { ) }\end{array}$ & $\begin{array}{l}-0.45[-0.78, \\
-0.11]\end{array}$ \\
\hline
\end{tabular}

\section{Analysis 5.1. Comparison 5: Fatigue: prostate cancer, Outcome 1: Exercise versus no exercise control; post-test means}

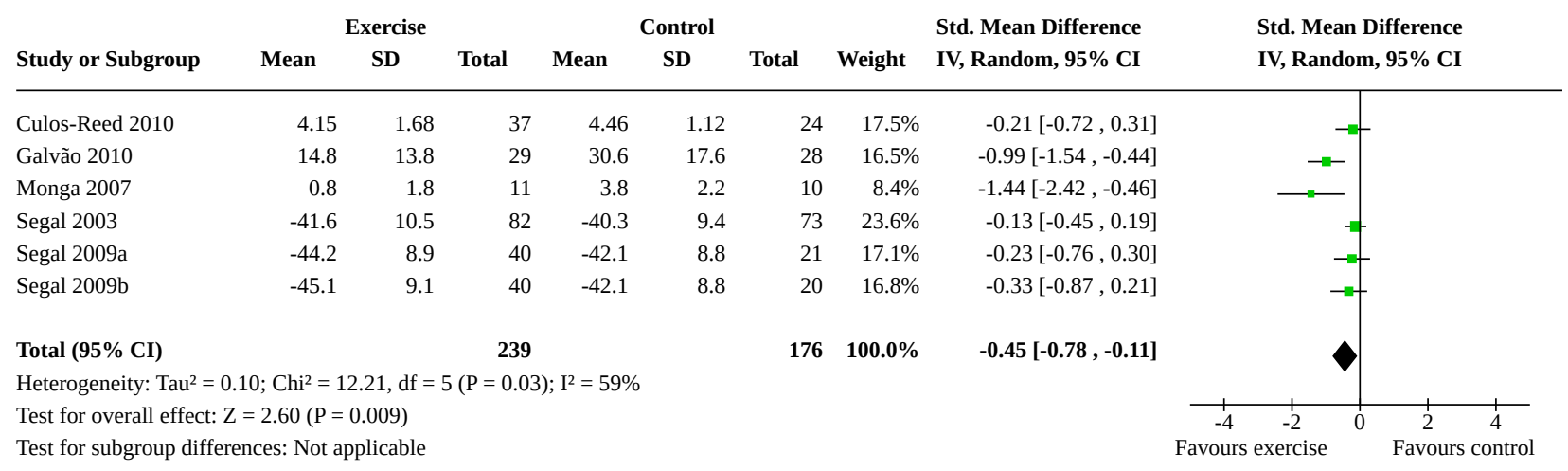

\section{Comparison 6. Fatigue: haematological malignancies}

\begin{tabular}{lllll}
\hline Outcome or subgroup title & No. of studies & $\begin{array}{l}\text { No. of partici- } \\
\text { pants }\end{array}$ & Statistical method & Effect size \\
\hline $\begin{array}{l}\text { 6.1 Exercise versus no exercise control; } \\
\text { post-test means }\end{array}$ & 4 & 220 & $\begin{array}{l}\text { Std. Mean Difference (IV, Ran- } \\
\text { dom, 95\% Cl) }\end{array}$ & $-0.15[-0.42,0.11]$ \\
\hline
\end{tabular}

Analysis 6.1. Comparison 6: Fatigue: haematological malignancies, Outcome 1: Exercise versus no exercise control; post-test means

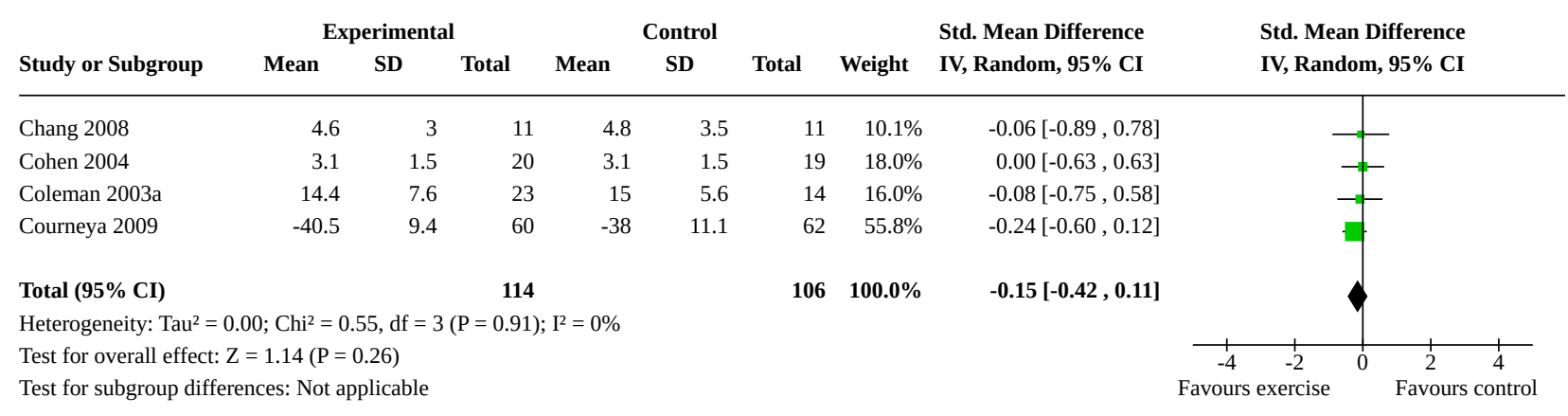




\section{Comparison 7. Fatigue: aerobic training}

\begin{tabular}{lllll}
\hline Outcome or subgroup title & No. of studies & $\begin{array}{l}\text { No. of partici- } \\
\text { pants }\end{array}$ & Statistical method & Effect size \\
\hline $\begin{array}{l}7.1 \text { Exercise versus no exercise control; } \\
\text { post-test means }\end{array}$ & 22 & 1533 & $\begin{array}{l}\text { Std. Mean Difference (IV, Ran- } \\
\text { dom, } 95 \% \text { Cl) }\end{array}$ & $\begin{array}{l}-0.22[-0.34, \\
-0.10]\end{array}$ \\
\hline
\end{tabular}

Analysis 7.1. Comparison 7: Fatigue: aerobic training, Outcome 1: Exercise versus no exercise control; post-test means

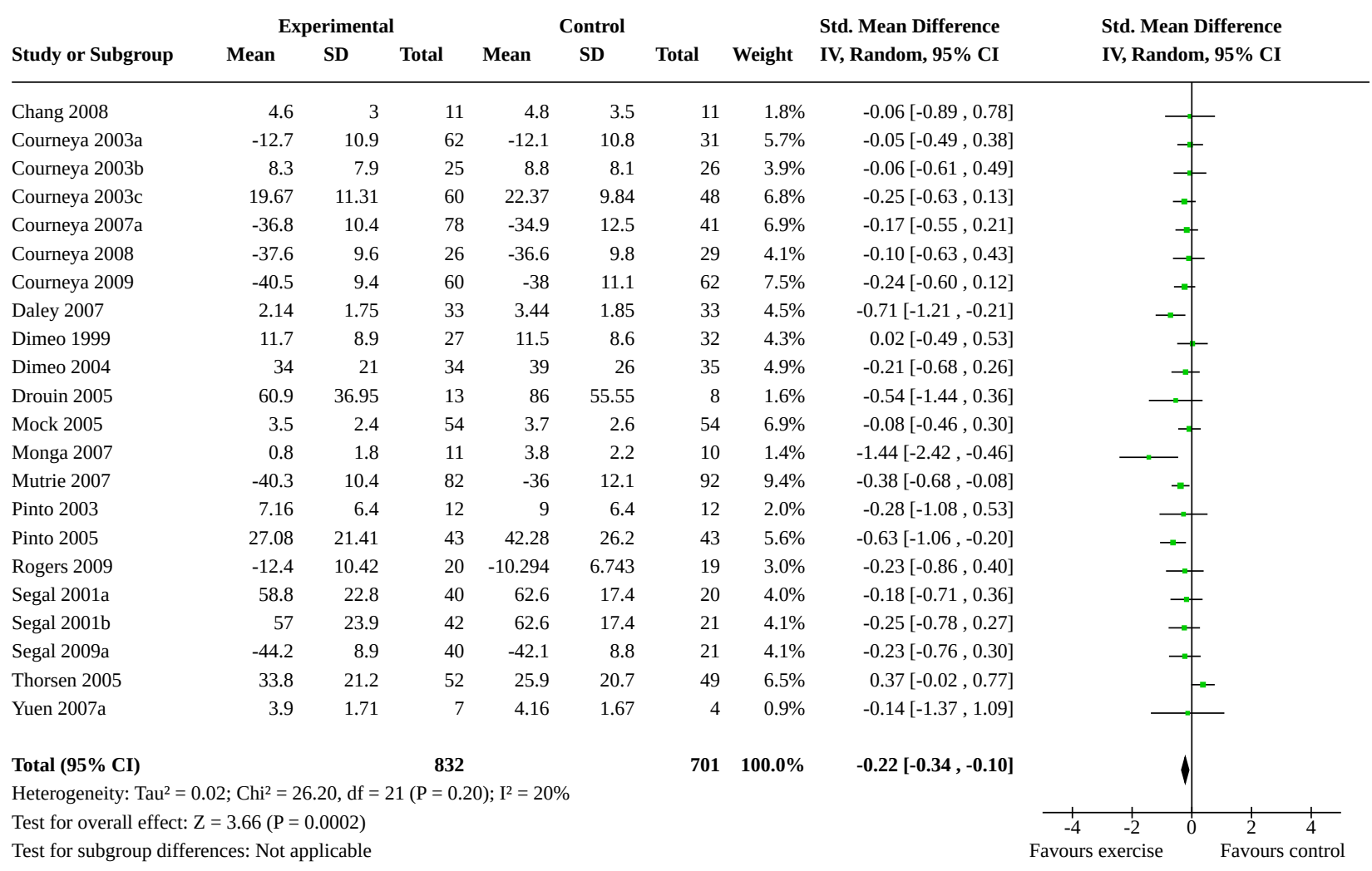

Comparison 8. Fatigue: resistance training

\begin{tabular}{lllll}
\hline Outcome or subgroup title & No. of studies & $\begin{array}{l}\text { No. of partici- } \\
\text { pants }\end{array}$ & Statistical method & Effect size \\
\hline $\begin{array}{l}\text { 8.1 Exercise versus no exercise control; } \\
\text { post-test means }\end{array}$ & 5 & 401 & $\begin{array}{l}\text { Std. Mean Difference (IV, Ran- } \\
\text { dom, 95\% Cl) }\end{array}$ & $-0.18[-0.39,0.02]$ \\
\hline
\end{tabular}


Analysis 8.1. Comparison 8: Fatigue: resistance training, Outcome 1: Exercise versus no exercise control; post-test means

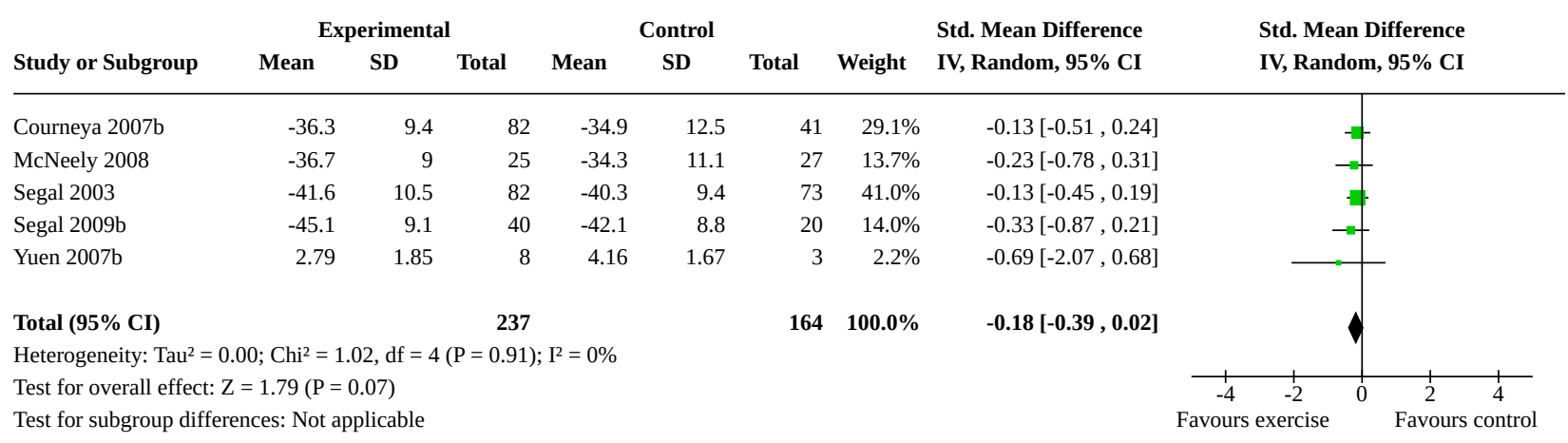

Comparison 9. Fatigue: mind-body exercise

\begin{tabular}{lllll}
\hline Outcome or subgroup title & No. of studies & $\begin{array}{l}\text { No. of partici- } \\
\text { pants }\end{array}$ & Statistical method & Effect size \\
\hline $\begin{array}{l}\text { 9.1 Exercise versus no exercise control; } \\
\text { post-test means }\end{array}$ & 3 & 194 & $\begin{array}{l}\text { Std. Mean Difference (IV, Ran- } \\
\text { dom, } 95 \% \text { Cl) }\end{array}$ & $-0.10[-0.39,0.19]$ \\
\hline
\end{tabular}

Analysis 9.1. Comparison 9: Fatigue: mind-body exercise, Outcome 1: Exercise versus no exercise control; post-test means

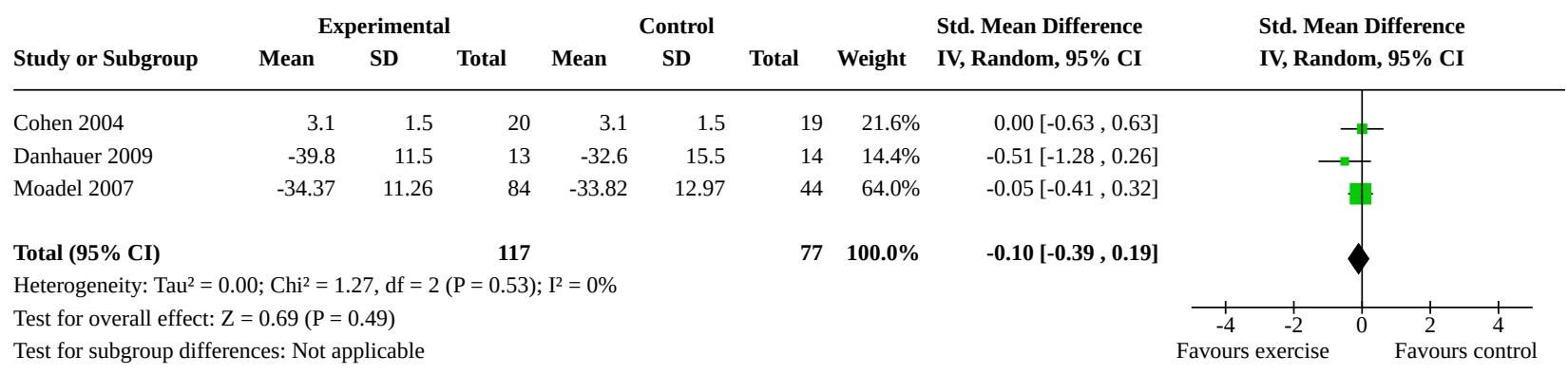

\section{APPENDICES}

\section{Appendix 1. Search strategy}

We used the following search strategy for this review, using text and keyword and MeSH terms in each database, with an RCT filter applied:

1. $\exp$ NEOPLASMS/

2. $\operatorname{exp~LEUKEMIA/~}$

3. exp LYMPHOMA/

4. exp RADIOTHERAPY/

5. BONE MARROW TRANSPLANTATION/

6. neoplasm\$.mp. [mp=title, original title, abstract, name of substance word, subject heading word]

7. cancer\$.mp. [mp=title, original title, abstract, name of substance word, subject heading word]

8. (leukaemi\$ or leukemi\$).mp. [mp=title, original title, abstract, name of substance word, subject heading word]

9. (tumour\$ or tumor\$).mp. [mp=title, original title, abstract, name of substance word, subject heading word]

10. malignan\$.mp. [mp=title, original title, abstract, name of substance word, subject heading word] 
11. neutropeni\$.mp. [mp=title, original title, abstract, name of substance word, subject heading word]

12. carcino\$.mp. [mp=title, original title, abstract, name of substance word, subject heading word]

13. adenocarcinoma\$.mp. [mp=title, original title, abstract, name of substance word, subject heading word]

14. lymphoma\$.mp. [mp=title, original title, abstract, name of substance word, subject heading word]

15. (radioth\$ or radiat\$ or irradiat\$ or radiochemo or chemotherapy\$).mp. [mp=title, original title, abstract, name of substance word, subject heading word]

16. (bone adj marrow adj5 transplant\$).mp. [mp=title, original title, abstract, name of substance word, subject heading word]

17. or/1-16

18. exp EXERCISE MOVEMENT TECHNIQUES/

19. ((exercise\$ or resistance or strength or flexibility or endurance) adj6 (train\$ or program\$)).mp. [mp=title, original title, abstract, name of substance word, subject heading word]

20. ((resistance or aerobic\$ or endurance\$) adj3 exercise\$).mp. [mp=title, original title, abstract, name of substance word, subject heading word]

21. (physical\$ adj3 (activ\$ or therap\$ or exercise\$)).mp. [mp=title, original title, abstract, name of substance word, subject heading word]

22. (interval training or sport\$ or movement therap\$).mp. [mp=title, original title, abstract, name of substance word, subject heading word]

23. stretching.mp.

24. (dance therap\$ or exercis\$ or "Tai Ji" or "Tai Chi" or "Tai-Ji" or "Tai-Chi" or walking or yoga).mp. [mp=title, original title, abstract, name of substance word, subject heading word]

25. or/18-24

26. FATIGUE/

27. fatigue.mp.

28. (tired\$ or weary or weariness or exhaustion or exhausted or lacklustre or ((astenia or asthenic) and syndrome) or ((lack or loss or lost) adj3 (energy or vigour))).mp. [mp=title, original title, abstract, name of substance word, subject heading word]

29. (apathy or apathetic or lassitude or weakness or lethargy or lethargic or (feeling adj3 (drained or sleepy or sluggish))).mp. [mp=title, original title, abstract, name of substance word, subject heading word]

30. or/26-29

31.17 and 25 and 30

The search was adapted as follows for each database:

\section{CENTRAL}

\#1 MeSH descriptor Neoplasms explode all trees

\#2 MeSH descriptor Leukemia explode all trees

\#3 MeSH descriptor Lymphoma explode all trees

\#4 MeSH descriptor Radiotherapy explode all trees

\#5 MeSH descriptor Bone Marrow Transplantation explode all trees

\#6 neoplasm or cancer $^{\star}$ or leukaemi ${ }^{\star}$ or leukemi ${ }^{\star}$ or tumour $^{\star}$ or tumor ${ }^{\star}$ or malignan ${ }^{\star}$ or neutropeni ${ }^{\star}$ or carcino* or adenocarcinoma* or lymphoma*

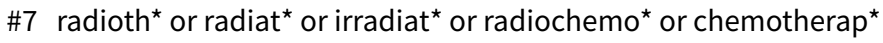

\#8 bone next marrow near/5 transplant *

\#9 (\#1 OR \#2 OR \#3 OR \#4 OR \#5 OR \#6 OR \#7 OR \#8)

\#10 MeSH descriptor Exercise Movement Techniques explode all trees

\#11 (exercise* or resistance or strength or flexibility or endurance) near/6 (train* or program*)

\#12 (resistance or aerobic ${ }^{*}$ or endurance ${ }^{\star}$ ) near/3 exercise*

\#13 physical $^{\star}$ near/3 (activ* or therap* or exercise*)

\#14 interval training or sport* or movement therap*

\#15 stretching

\#16 dance therap* or exercis* or "Tai Ji" or "Tai Chi" or "Tai-Ji" or "Tai-Chi" or walking or yoga

\#17 (\#10 OR \#11 OR \#12 OR \#13 OR \#14 OR \#15 OR \#16) 
\#18 MeSH descriptor Fatigue, this term only

\#19 fatigue

\#20 tired $^{\star}$ or weary or weariness or exhaustion or exhausted or lacklustre or ((astenia or asthenic) and syndrome) or ((lack or loss or lost) near/3 (energy or vigour))

\#21 apathy or apathetic or lassitude or weakness or lethargy or lethargic or (feeling near/3 (drained or sleepy or sluggish))

\#22 (\#18 OR \#19 OR \#20 OR \#21)

\#23 (\#9 AND \#17 AND \#22)

\section{MEDLINE Ovid}

1 exp NEOPLASMS/

2 exp LEUKEMIA/

3 exp LYMPHOMA/

4 exp RADIOTHERAPY/

5 Bone Marrow Transplantation/

6 neoplasm\$.mp.

7 cancer\$.mp.

8 (leukaemi\$ or leukemi\$).mp.

9 (tumour\$ or tumor\$).mp.

10 malignan\$.mp.

11 neutropeni\$.mp.

12 carcino\$.mp.

13 adenocarcinoma\$.mp.

14 lymphoma\$.mp.

15 (radioth\$ or radiat\$ or irradiat\$ or radiochemo\$ or chemotherap\$).mp.

16 (bone adj marrow adj5 transplant\$).mp.

17 or/1-16

18 exp Exercise Movement Techniques/

19 ((exercise\$ or resistance or strength or flexibility or endurance) adj6 (train\$ or program\$)).mp.

20 ((resistance or aerobic\$ or endurance\$) adj3 exercise\$).mp.

21 (physical\$ adj3 (activ\$ or therap\$ or exercise\$)).mp.

22 (interval training or sport\$ or movement therap\$).mp.

23 stretching.mp.

24 (dance therap\$ or exercis\$ or "Tai Ji" or "Tai Chi" or "Tai-Ji" or "Tai-Chi" or walking or yoga).mp.

25 or/18-24

26 Fatigue/

27 fatigue.mp. 
28 (tired\$ or weary or weariness or exhaustion or exhausted or lacklustre or ((astenia or asthenic) and syndrome) or ((lack or loss or lost) adj3 (energy or vigour))).mp.

29 (apathy or apathetic or lassitude or weakness or lethargy or lethargic or (feeling adj3 (drained or sleepy or sluggish))).mp.

30 or $/ 26-29$

3117 and 25 and 30

32 randomized controlled trial.pt.

33 controlled clinical trial.pt.

34 randomized.ab.

35 placebo.ab.

36 clinical trials as topic.sh.

37 randomly.ab.

38 trial.ti.

3932 or 33 or 34 or 35 or 36 or 37 or 38

4031 and 39

key:

$\mathrm{mp}=$ title, abstract, subject headings, heading word, drug trade name, original title, device manufacturer, drug manufacturer

$a b=a b s t r a c t$

pt $=$ publication type

sh = subject heading

$\mathrm{ti}=$ title

\section{EMBASE Ovid}

1 exp neoplasm/

2 exp leukemia/

3 exp lymphoma/

4 exp radiotherapy/ or exp cancer radiotherapy/

5 exp bone marrow transplantation/

6 (neoplasm $^{\star}$ or cancer ${ }^{\star}$ or leukaemi ${ }^{\star}$ or leukemi ${ }^{\star}$ or tumor ${ }^{\star}$ or tumour ${ }^{\star}$ or malignan ${ }^{\star}$ or neutropeni ${ }^{\star}$ or carcino* or adenocarcinoma* or lymphoma*).mp.

7 (radioth $^{\star}$ or radiat* $^{\star}$ or irradiat* or radiochemo* or chemotherap*).mp.

8 (bone adj marrow adj5 transplant*).mp.

91 or 2 or 3 or 4 or 5 or 6 or 7 or 8

10 exp kinesiotherapy/

11 ((exercise* or resistance or strength or flexibility or endurance) adj6 (train* or program*)).mp.

12 ((resistance or aerobic ${ }^{\star}$ or endurance*) adj3 exercise $\left.{ }^{\star}\right)$.mp.

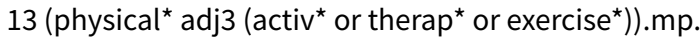

14 (interval training or sport* or movement therap*).mp.

Exercise for the management of cancer-related fatigue in adults (Review) 
15 stretching.mp.

16 (dance therap* or exercis or "Tai Ji" or "Tai Chi" or "Tai-Ji" or "Tai-Chi" or walking or yoga).mp.

1710 or 12 or 13 or 14 or 15 or 16

18 exp fatigue/

19 fatigue.mp.

20 (tired $^{\star}$ or weary or weariness or exhaustion or exhausted or lacklustre or ((astenia or asthenic) and syndrome) or ((lack or loss or lost) $\operatorname{adj} 3$ (energy or vigour))).mp.

21 (apathy or apathetic or lassitude or weakness or lethargy or lethargic or (feeling adj3 (drained or sleepy or sluggish))).mp.

2218 or 19 or 20 or 21

239 and 17 and 22

\section{4 crossover procedure/}

25 double blind procedure/

26 randomized controlled trial/

27 single blind procedure/

28 random*$^{\star} . \mathrm{mp}$.

29 factorial $^{\star} . \mathrm{mp}$.

30 crossover $^{\star} . \mathrm{mp}$.

31 cross over ${ }^{\star} . \mathrm{mp}$.

32 cross-over $^{\star} . \mathrm{mp}$.

33 placebo*.mp.

34 (doubl $^{\star}$ adj blind $\left.{ }^{\star}\right) . m p$.

35 (single ${ }^{\star}$ adj blind $\left.{ }^{\star}\right) \cdot m p$.

36 assign $^{\star} . \mathrm{mp}$.

37 allocat $^{\star} \cdot \mathrm{mp}$.

38 volunteer ${ }^{\star} . \mathrm{mp}$.

3924 or 26 or 27 or 28 or 29 or 30 or 31 or 32 or 33 or 34 or 35 or 36 or 37 or 38

4023 and 39

key:

[mp = title, abstract, subject headings, heading word, drug trade name, original title, device manufacturer, drug manufacturer]

\section{WHAT'S NEW}

\begin{tabular}{lll}
\hline Date & Event & Description \\
\hline 29 September 2021 & Amended & Published Note text updated. \\
\hline 3 July 2015 & Review declared as stable & This review will be superseded. See Published notes. \\
\hline
\end{tabular}




\section{HISTORY}

Protocol first published: Issue 3, 2006

Review first published: Issue 2, 2008

\begin{tabular}{lll}
\hline Date & Event & Description \\
\hline 19 April 2012 & New search has been performed & We ran update searches for studies in March 2011. \\
\hline 19 April 2012 & $\begin{array}{l}\text { New citation required and conclusions } \\
\text { have changed }\end{array}$ & $\begin{array}{l}\text { The updated review includes an additional 28 studies; a further } \\
22 \text { were identified but excluded. We have also added 'Risk of } \\
\text { bias' tables. The conclusions have been further developed to } \\
\text { identify the 'type' of exercise (aerobic) necessary to reduce can- } \\
\text { cer-related fatigue. }\end{array}$ \\
\hline 24 September 2010 & Amended & Contact details updated. \\
\hline 30 October 2008 & Amended & Converted to new review format. \\
\hline
\end{tabular}

\section{CONTRIBUTIONS OF AUTHORS}

FC led the review from the initiation of the protocol and has been responsible for the retrieval, screening and data extraction process as well as writing the review. In the updated review FC was responsible for the retrieval of new studies, screening and data extraction and re-writing the review.

JB-D screened all the studies, carried out data extraction for comparison purposes and contributed to the writing of the review. In the updated review JB-D screened all the studies, carried out data extraction on the new studies that were identified for inclusion and contributed to the writing of the final review.

\section{DECLARATIONS OF INTEREST}

None known.

\section{SOURCES OF SUPPORT}

\section{Internal sources}

- Faculty of Health and Social Care, University of the West of England, UK

\section{External sources}

- National Institute for Health Research (NIHR) Health Technology Assessment programme, UK

HTA Project: 10/81/01 - Exercise interventions for the management of health related quality of life and fatigue in cancer survivors during and after treatment.

\section{DIFFERENCES BETWEEN PROTOCOLANDREVIEW}

In the updated review it was decided a priori to carry out separate subgroup analysis based upon the mode of exercise. We also added 'Risk of bias' tables for all studies. There were no other changes between the protocol and review.

\section{NOTES}

This review will be superseded by a new title. The new protocol will aim to include studies investigating physical activity, including exercise, in which fatigue management is a specific target of the intervention.

\section{INDEX TERMS}

\section{Medical Subject Headings (MeSH)}

*Exercise [physiology]; Fatigue [etiology] [therapy]; Neoplasms [ ${ }^{*}$ complications] [therapy]; Randomized Controlled Trials as Topic 


\section{MeSH check words}

Adult; Female; Humans; Male 